\section{Photovoltaics Value Analysis}

Subcontract Report NREL/SR-581-42303

J.L. Contreras, L. Frantzis, S. Blazewicz, D. Pinault, and H. Sawyer

Navigant Consulting Inc.

Burlington, Massachusetts
February 2008

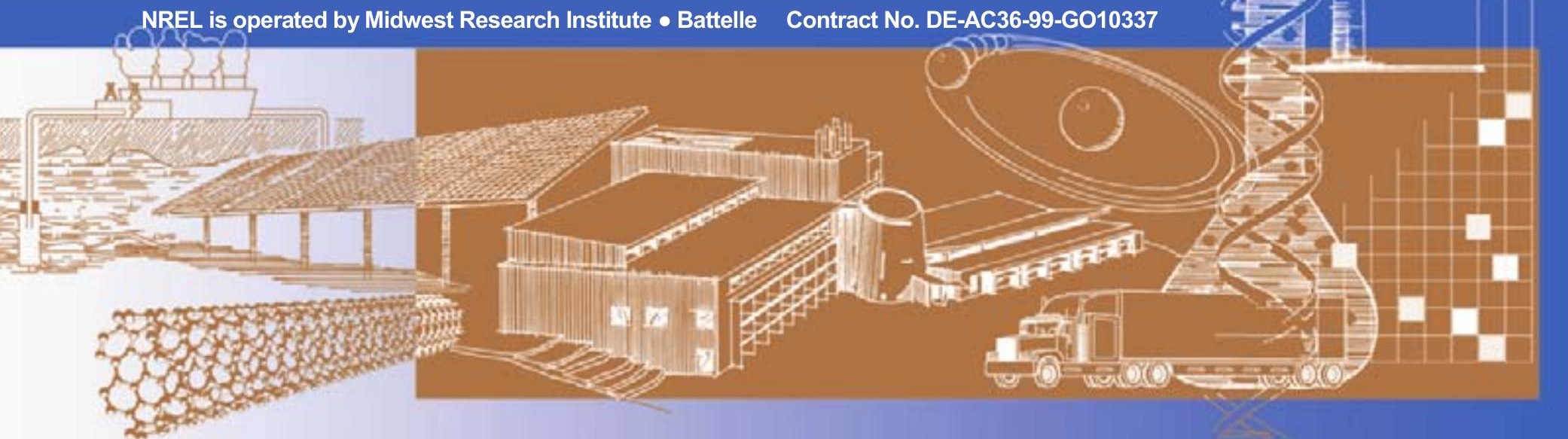




\section{Photovoltaics Value Analysis}

\section{J.L. Contreras, L. Frantzis, S. Blazewicz,}

D. Pinault, and $\mathrm{H}$. Sawyer

Navigant Consulting Inc.

Burlington, Massachusetts

NREL Technical Monitor: Robert Margolis

Prepared under Subcontract No. KACX-4-44451-08

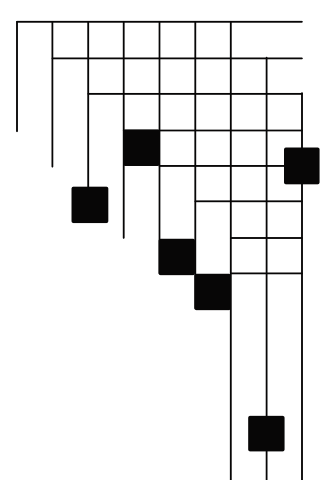




\section{NOTICE}

This report was prepared as an account of work sponsored by an agency of the United States government. Neither the United States government nor any agency thereof, nor any of their employees, makes any warranty, express or implied, or assumes any legal liability or responsibility for the accuracy, completeness, or usefulness of any information, apparatus, product, or process disclosed, or represents that its use would not infringe privately owned rights. Reference herein to any specific commercial product, process, or service by trade name, trademark, manufacturer, or otherwise does not necessarily constitute or imply its endorsement, recommendation, or favoring by the United States government or any agency thereof. The views and opinions of authors expressed herein do not necessarily state or reflect those of the United States government or any agency thereof.

Available electronically at http://www.osti.gov/bridge

Available for a processing fee to U.S. Department of Energy and its contractors, in paper, from:

U.S. Department of Energy

Office of Scientific and Technical Information

P.O. Box 62

Oak Ridge, TN 37831-0062

phone: 865.576 .8401

fax: 865.576 .5728

email: mailto:reports@adonis.osti.gov

Available for sale to the public, in paper, from:

U.S. Department of Commerce

National Technical Information Service

5285 Port Royal Road

Springfield, VA 22161

phone: 800.553 .6847

fax: 703.605.6900

email: orders@ntis.fedworld.gov

online ordering: http://www.ntis.gov/ordering.htm

This publication received minimal editorial review at NREL 


\section{Preface}

Now is the time to plan for the integration of significant quantities of distributed renewable energy into the electricity grid. Concerns about climate change, the adoption of state-level renewable portfolio standards and incentives, and accelerated cost reductions are driving steep growth in U.S. renewable energy technologies. The number of distributed solar photovoltaic (PV) installations, in particular, is growing rapidly. As distributed PV and other renewable energy technologies mature, they can provide a significant share of our nation's electricity demand. However, as their market share grows, concerns about potential impacts on the stability and operation of the electricity grid may create barriers to their future expansion.

To facilitate more extensive adoption of renewable distributed electric generation, the U.S. Department of Energy launched the Renewable Systems Interconnection (RSI) study during the spring of 2007. This study addresses the technical and analytical challenges that must be addressed to enable high penetration levels of distributed renewable energy technologies. Because integration-related issues at the distribution system are likely to emerge first for PV technology, the RSI study focuses on this area. A key goal of the RSI study is to identify the research and development needed to build the foundation for a high-penetration renewable energy future while enhancing the operation of the electricity grid.

The RSI study consists of 15 reports that address a variety of issues related to distributed systems technology development; advanced distribution systems integration; system-level tests and demonstrations; technical and market analysis; resource assessment; and codes, standards, and regulatory implementation. The RSI reports are:

- Renewable Systems Interconnection: Executive Summary

- Distributed Photovoltaic Systems Design and Technology Requirements

- Advanced Grid Planning and Operation

- Utility Models, Analysis, and Simulation Tools

- Cyber Security Analysis

- Power System Planning: Emerging Practices Suitable for Evaluating the Impact of High-Penetration Photovoltaics

- Distribution System Voltage Performance Analysis for High-Penetration Photovoltaics

- Enhanced Reliability of Photovoltaic Systems with Energy Storage and Controls

- Transmission System Performance Analysis for High-Penetration Photovoltaics

- Solar Resource Assessment

- Test and Demonstration Program Definition

- Photovoltaics Value Analysis

- Photovoltaics Business Models 
- Production Cost Modeling for High Levels of Photovoltaic Penetration

- Rooftop Photovoltaics Market Penetration Scenarios.

Addressing grid-integration issues is a necessary prerequisite for the long-term viability of the distributed renewable energy industry, in general, and the distributed PV industry, in particular. The RSI study is one step on this path. The Department of Energy is also working with stakeholders to develop a research and development plan aimed at making this vision a reality. 


\section{Acknowledgments}

We would like to acknowledge the input provided by industry experts such as Christy Herig, Thomas Hoff, Ed Kern, Peter Kobos, Ben Kroposki, Robert Margolis, Richard Perez, Howard Wenger, and EPRI. 


\section{List of Abbreviations and Acronyms}

$\begin{array}{ll}\text { AE } & \text { Austin Energy } \\ \text { CAISO } & \text { California Independent System Operator } \\ \text { CAPM } & \text { Capital Asset Pricing Model } \\ \text { CEC } & \text { California Energy Commission } \\ \text { CO }_{2} & \text { Carbon Dioxide } \\ \text { CSE } & \text { Centre for Sustainable Energy } \\ \text { \& kWh } & \text { Cents per Kilowatt Hour } \\ \text { DG } & \text { Distributed Generation } \\ \text { DOE } & \text { Department of Energy } \\ \text { E3 } & \text { Energy and Environmental Economics, Inc. } \\ \text { EC } & \text { European Commission } \\ \text { ELCC } & \text { Effective Load Carrying Capacity factor } \\ \text { ERC } & \text { Emission Reduction Credits } \\ \text { GHG } & \text { Green House Gas } \\ \text { GT } & \text { Gas Turbine } \\ \text { MTC } & \text { Massachusetts Technology Collaborative } \\ \text { MW } & \text { Megawatt } \\ \text { NCI } & \text { Navigant Consulting, Inc. } \\ \text { NG } & \text { Natural Gas } \\ \text { NOx } & \text { Nitrogen Oxide } \\ \text { NPV } & \text { Net Present Value } \\ \text { NREL } & \text { National Renewable Energy Laboratory } \\ \text { NYMEX } & \text { New York Mercantile Exchange } \\ \text { O\&M } & \text { Operation and Maintenance } \\ \text { PG\&E } & \text { Pacific Gas \& Electric } \\ \text { PV } & \text { Photovoltaics } \\ \text { REC } & \text { Renewable Energy Credits } \\ \text { R\&D } & \text { Research and Development } \\ \text { SOx } & \text { Sulfur Oxide } \\ & \end{array}$




\section{Executive Summary}

This report is part of a set of studies launched by the U.S. Department of Energy (DOE) and the National Renewable Energy Laboratory (NREL) to define a research agenda that will advance and enable a high penetration of renewable energy into the existing electricity grid. It specifically examines the value of photovoltaic (PV) systems to participating customers, utilities/ratepayers, and society. The study reviews existing published reports on the value of PV, summarizes the methodologies and quantification of PV values, and identifies research and development $(R \& D)$ that needs to be completed to fill in knowledge gaps.

\section{PV Values}

We identified 19 key values of distributed PV. These values are described in Table E-1.

Table E-1. PV Values

\begin{tabular}{|c|c|}
\hline PV Value & Description \\
\hline $\begin{array}{l}\text { Central Power Generation } \\
\text { Cost }\end{array}$ & $\begin{array}{l}\text { PV systems produce electricity, reducing the amount of electricity that needs to be generated } \\
\text { at other plants, which in turn decreases fuel and other O\&M costs. }\end{array}$ \\
\hline $\begin{array}{l}\text { Central Power Capacity } \\
\text { Cost }\end{array}$ & $\begin{array}{l}\text { PV indirectly avoids and/or defers central power plant capacity investments by reducing } \\
\text { demand-side consumption. Generatson capacity value is the economic value of the avoided } \\
\text { and/or deferred incremental resource (typically natural gas turbine) reflecting PV's peak } \\
\text { load reduction. NIMBY opposition and higher construction costs are driving capacity costs } \\
\text { up. PV also avoids the cost of runnting more expensive plants during peak. loads. }\end{array}$ \\
\hline$T \& D$ Cost & $\begin{array}{l}\text { PV avoids and/or defers transmission and distribution capacity investments by reducing } \\
\text { demand-side consumption. Transmission and distribution capacity value is the economic } \\
\text { value of the a voided and/or deferred incremental resource reflecting PV's peak load } \\
\text { reduction. NIMBY oppostion and higher construction costs are driving capacity costs up. } \\
\text { This value is also applicable to situations involving significant congestion isstes. }\end{array}$ \\
\hline System Losses & $\begin{array}{l}\text { Avoided electric system losses are an indirect benefit because they increase the value of other } \\
\text { benefits including energy production, generation capacity, environmental and T\& D capacity. }\end{array}$ \\
\hline Ancillary Services & $\begin{array}{l}\text { Utilities can use inverters in PV systems to provide reactive power back to the grid. This } \\
\text { increases power quality and could aroid the installation of capacitors. }\end{array}$ \\
\hline System Resiliency & $\begin{array}{l}\text { Significant deployment of PV systems coupled with storage could provide dizaster recovery } \\
\text { benefits. }\end{array}$ \\
\hline Hedge Value & $\begin{array}{l}\text { Current electricity generation is heavily dependant on natural gas and coal. Recent } \\
\text { environmental constraints suggest that utilities will become more dependent on natural gas. } \\
\text { PV lessens the exposure of the utility to volatile fuel prices and provides stable and } \\
\text { predictable electricity prices. }\end{array}$ \\
\hline $\begin{array}{l}\text { Market Price } \\
\text { Impacts/Elasticity }\end{array}$ & $\begin{array}{l}\text { The elasticity of demand for electricity supply increases with more PV. Increased demand } \\
\text { for PV may decrease the price of electricity from PV, spur market development, thereby } \\
\text { further reducing the cost of PV. A decrease in the cost may then increase the demand for } \\
\text { this lower cost good. }\end{array}$ \\
\hline $\begin{array}{l}\text { Customer Electricity Price } \\
\text { Protection }\end{array}$ & $\begin{array}{l}\text { Since there is no fuel expense, the costs of electricty from FV will not increase over the life of } \\
\text { the system due to fuel costs and the consumer effectively locks in an electricity price. }\end{array}$ \\
\hline Customer Reliability & $\begin{array}{l}\text { PV can provide electricity to the PV owner during outages because it is not dependent on the } \\
\text { grid. The electricity during an outage is limited to sunlight a aailability. Storage systems } \\
\text { could help offset the intermittency issue and increase the relsability value to the owner. }\end{array}$ \\
\hline $\begin{array}{l}\text { Criteria Pollutant } \\
\text { Emissions }\end{array}$ & $\begin{array}{l}\text { PV systems climinate criteria pollutant emissions ( } \mathrm{c} \cdot \mathrm{g}, \mathrm{NO}_{s} \mathrm{SO}_{\mathrm{J}} \text { ) associated with non- } \\
\text { renewable generation resources. Health benefits associated with reduced ernissons are } \\
\text { included in this palue. }\end{array}$ \\
\hline $\begin{array}{l}\text { Greenhouse Gas } \\
\text { Emissions }\end{array}$ & $\begin{array}{l}\text { PV systems eliminate greenhouse gases }\left(\mathrm{CO}_{2}\right) \text { associated with non-fenewable generation } \\
\text { resources. Renewable Portfolio Standards (RPS) and Renewable Energy Certificates ( } \mathrm{REC} \text { s) } \\
\text { are common mecharisms to value emission reductions from renewable sources of energy } \\
\text { such as PV. }\end{array}$ \\
\hline Implicit Value of PV & $\begin{array}{l}\text { The intrinssc societal value of PV to customere (e.g., environmental friendlinese, feeling } \\
\text { good, early adopter) and utilities (e.g., public relations, regulator compliance). }\end{array}$ \\
\hline
\end{tabular}




\begin{tabular}{|l|l|}
\hline $\begin{array}{l}\text { PV System Equipment } \\
\text { and Installation Cost }\end{array}$ & $\begin{array}{l}\text { The cost of equipment (PV array, inverter, battery, transformer etc.), engineering design } \\
\text { and construction for a PV system. }\end{array}$ \\
\hline PV System O\&M Cost & $\begin{array}{l}\text { This accounts for operations and maintenance expenses for the PV system. As PV cost is } \\
\text { almost enturely capital, ongoing O\&M costs are negligible. }\end{array}$ \\
\hline Benefits Overhead & $\begin{array}{l}\text { Costs associated with capturing and monetizing the value streams. Includes program } \\
\text { administration, marketing and equipment costs (e.g. advanced metering). }\end{array}$ \\
\hline PV Owner Electricity Bill & $\begin{array}{l}\text { PV systems produce electricity therefore owners consume less electricity from the electric } \\
\text { power system reducing their electric bill and the revenues to utilitieg/ratepayers. }\end{array}$ \\
\hline Federal Incentives & $\begin{array}{l}\text { Federal rebates offered to promote residential and commercial PV system that off sets } \\
\text { initial investment costs though federal tax credits. }\end{array}$ \\
\hline State Incentives & $\begin{array}{l}\text { Incentives offered by States to promote PV systems, either through initial investment } \\
\text { rebates or production credits. }\end{array}$ \\
\hline
\end{tabular}

\section{Quantification of PV Values}

PV values were quantified and allocated to several categories of stakeholders: customer participant, utilities/ratepayers, and society. Customer participants take the perspective of PV system owners and end-users. Utilities/ratepayers represent all electric utility customers in the region. Finally, society represents the general population.

We analyzed existing methodologies to quantify the PV values. A range for each value was calculated, because PV values have multiple drivers. Table E-2 summarizes the PV value ranges. On average, the values with the highest net benefits are central power generation cost savings, central power capacity costs, transmission and design (T\&D) costs, greenhouse gas (GHG) emissions, criteria pollutant emissions, and implicit value of PV. The value with the highest net cost is PV equipment \& installation.

Table E-2. PV Values Ranges

\begin{tabular}{|c|c|c|c|c|c|c|}
\hline & PV Values & $\begin{array}{l}\text { Customer } \\
\text { Particlpant }\end{array}$ & $\begin{array}{c}\text { Utility/ } \\
\text { Ratepayers }\end{array}$ & $\begin{array}{l}\text { Society } \\
\text { (c/kWhy }\end{array}$ & 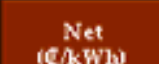 & Value Dilvers \\
\hline \multirow{13}{*}{ 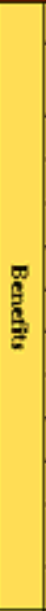 } & Central Powrer Generation Cost & & $32-97$ & & $3.2-9.7$ & Gas price, heat nate \\
\hline & Central Power Capacity Cost & & $11-108$ & & $1.1-10.8$ & $\begin{array}{l}\text { Etfective load carrying capacity factor, gas } \\
\text { turbine capital coet, life adjustment }\end{array}$ \\
\hline & T\&D Costs & & $0.1-10.0$ & & $0.1-10.0$ & Location, growth, climate \\
\hline & System Loses & & $0.5-4.3$ & & $0.5-4.3$ & Location, time period, other benefits \\
\hline & Ancillary Services & & $0-1.5$ & & $0-1.5$ & Ancillary service prices, voltage support \\
\hline & System Resiliency & & Low & & Low & Quantification methodology unclear \\
\hline & Hedge Value & & $0=09$ & & $0-0.9$ & Gas price forecusts, futures, heat mate \\
\hline & Market Price Impacts/Elastidty & & Low & & Low & Quantification methodology unclear \\
\hline & Customer Price Protection & $0.5-1.0$ & & & $0.5-1.0$ & Calculation method \\
\hline & Customer Relsability & Low & & & Low & Quantification methodology unclear \\
\hline & Criteria Pollutant Emiastons & & & $0.02-20$ & $0.02-2 . \Omega$ & Market value of emisaiona \\
\hline & Greenhouse Gas Emissions & & & $0.02-4.2$ & $0.02-4.2$ & $\begin{array}{l}\text { Reduction costs, market value, diecount } \\
\text { rate }\end{array}$ \\
\hline & Implicit Value of PV & & & $0-20$ & $0-2.0$ & Customer willingness to pay premium \\
\hline \multirow{3}{*}{$\begin{array}{l}8 \\
\frac{2}{2}\end{array}$} & Equipment and Installation & $(47)-(19)$ & & & $(47)-(19)$ & Size, location \\
\hline & PV O\&M Expenses & $(0.15)-(0.05)$ & & & $(0.15)-(0.05)$ & Type of system \\
\hline & Benefits Overhead & & $(0.2)-(0.1)$ & & $(0.2)-(0.1)$ & Infrustructure and administrative costs \\
\hline \multirow{3}{*}{$\vec{E}$} & PV Owner Electricity Bill & $1.1-33.0$ & $(33.0)-(1.1)$ & & - & Customer type, rate structure, load prosile \\
\hline & Federal Incentives & $1.58-7.95$ & & $(7.95)-(1.58)$ & - & Customer type, size, cap \\
\hline & State Incentives & $0-178$ & & $(178)=0$ & - & State, customer type, sise, production, cap \\
\hline & Stakeholder Total & $(4397)-407$ & $(283)-360$ & $(25.7)-6.6$ & $(41.9)-27.3$ & \\
\hline
\end{tabular}




\section{Drivers of PV Value}

The two main drivers for the highest magnitude values are location of the PV system and output profile or timing of the power output of the system. As illustrated in Figure E-1., a PV system will have higher benefits when it is located in a highly congested distribution system, where there is high insolation to increase production of the PV system, and where gas prices are high. PV systems will also have higher net benefits when a large share of their production is during peak demand periods, when the systems can displace expensive peaking plants, which have lower efficiency and utilization, and use more expensive fuel.

Figure E-1. Key Drivers of PV Values

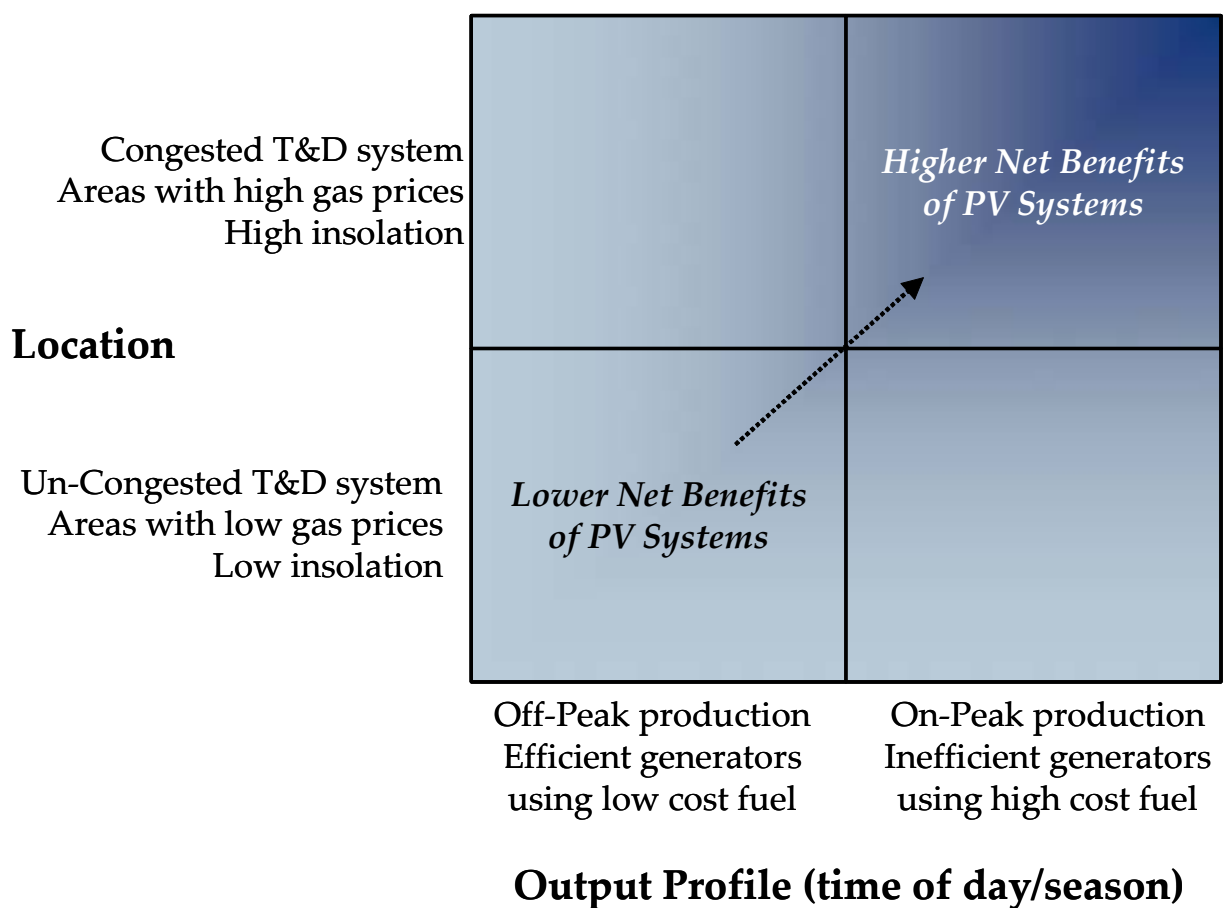

Central Power Generation Cost. Natural gas-fueled power plants are used as the marginal generation resource in many regions of the United States. As a result, natural gas prices in the region and the marginal resource heat rate (i.e., the amount of gas consumed to generate a kilowatt-hour [kWh]) are two key drivers of this value. Given these drivers, a PV system in a region with high gas prices that generates most of its power during peak-time and displaces electricity from a peaking power plant with a high heat rate will have a higher benefit than a PV system in a region with low gas prices that produces most of its power off-peak, displacing electricity from a baseload power plant with a low heat rate. A strategy to improve the benefit from this value is to increase production from the PV system by optimizing orientation (i.e., latitude and tilt) and using tracking systems.

Central Power Capacity Cost. The key driver for this value is the coincidence of peak demand with system output. Another key driver is the type of generation asset displaced. Peaking plants typically have lower capital costs than baseload plants. However, a peaking plant that runs a limited number of hours per year will have a higher capital cost 
per kilowatt-hour than a baseload plant. Given these drivers, a system that produces a high share of its output during on-peak hours and displaces a peaking plant will have a higher benefit. Various strategies to increase production during peak demand periods and increase the benefit from this value include: integrating energy storage to the PV system, and integrating load management applications with the PV system controls.

$T \& D$ Cost. While this value has significant potential, it has been difficult to capture. This value depends on the location of the PV system as well as the output during the T\&D system's peak period. Locations with congested transmission and/or distribution systems typically require expensive upgrades that could be deferred where PV systems are installed to reduce congestion. Although this value includes both transmission and distribution, there are cases that are specific to one or the other. For example, PV can be installed in an area that reduces the transmission peak, but is in a distribution area with excess capacity, providing limited value to the distribution system. However, some of the most congested areas have network distribution systems in which interconnection standards currently prohibit or severely limit interconnections. And in non-network distribution systems, the deferral depends on the production of the PV system during the peak of the specific distribution area, which varies across the distribution system and can be a different peak period than the regional generation peak.

Many distribution planners will also want "physical assurance" (i.e., guarantees that the load the PV is serving is permanently displaced). Another barrier for this value is the potential for circuit overload following an outage or a recloser operation. Current interconnection standards (e.g., IEEE 1547) prohibit PV systems from riding through outages, leaving the T\&D system to support the loads that would otherwise be served by the PV systems. For a local utility to defer T\&D upgrades and capture the benefits of this value, it will need to assure that the PV system will effectively eliminate a certain load during its peak congestion period and that it will not suffer a load surge after outages. PV inverter-based load management systems would allow PV systems to capture the T\&D cost benefits. Other strategies to increase the benefits captured from this value are to improve the ability to install PV systems in congested areas with limited roof space, and to firm PV output with storage and/or demand response.

Greenhouse Gas. This value is driven by two key factors: the amount of emissions displaced by the PV system and the value of the displaced emissions. PV systems have no point source emissions at the demand site, and therefore displace all the emissions otherwise associated with siting the marginal central generation resource. In most cases, the marginal resource will be a gas-fueled central generation plant. The higher the heat rate, the higher the displaced emissions. Coincidence of peak demand with PV system output also plays a role in this value as peaking plants tend to have a higher heat rate than baseload plants, producing higher emissions. There are several ways to value displacedGHG emissions: placing a price on carbon through a carbon tax, employing a cap-and-trade program, or creating renewable portfolio standard/renewable energy credit markets. The variety of valuation mechanisms has created a wide range of economic benefits for this value. Moreover, the climate and energy context is evolving quickly and producing an upward trend in the future economic value of the emissions reduction. A 
strategy to increase the benefits from this value is to support the development and adoption of a uniform valuation standard across the country. A secondary strategy is to increase the amount of displaced emissions by aligning the PV system production with peak demand periods, when dirtier peaking generation plants are the marginal resource.

Criteria Pollutant Emissions. Two methods of determining the value of offsetting criteria pollutant emissions are the avoided penalty/cost and the health benefits. These methods involve assessing the public health impact, regional air quality district emissions permit trading systems, regional renewable energy credit trading systems, penalties of failing to meet emission standards, and projecting the cost of achieving target emissions reductions. The strategies for increasing this benefit are similar to the GHG emission strategies; however, there are already regulations in place for many states.

Implicit Value of $P V$. This value is driven by customers' willingness to pay a premium price for electricity from a PV system. For some commercial customers, this value could come from demonstrating to their key stakeholders (customers, investors, employees, regulators) that the organization is environmentally friendly. For some residential customers, this value could come from a desire to reduce their environmental impact, create an image of being environmentally friendly, and/or create an image of being an early adopter of emerging technologies. The magnitude of this value across market segments is still unclear. Furthermore, this value may change over time as PV penetrates the market. The implicit value may decline as PV becomes more common. Or conversely, PV may become a "must-have" product for some sectors of the economy. Understanding what creates this value and how it will change over time will be critical to the success of PV.

Equipment and Installation Cost. This value is driven by three key factors: system size, location, and projected long-term costs (i.e., financing). Financing is an important aspect of cost - it varies depending on size and length of payments, interest rates, etc. A typical levelized cost for a residential retrofit system is 29.26 cents $/ \mathrm{kWh}$, while the cost for a typical commercial retrofit system is 26.49 cents/kWh. Large systems have a lower cost per output unit than smaller systems as some PV system costs (e.g., design, engineering, transportation, installation, permitting, and incentive request) are mostly fixed. The location is also a factor as labor rates in some regions are more expensive than others, driving up the labor-intensive costs (e.g., design, engineering, and installation).

As the industry continues to grow and mature, economies of scale and learning curves across the supply chain are expected to reduce overall system costs. However, it is still unclear exactly how much costs will come down, and projections have significant variance. A strategy to reduce the cost from this value is to continue to promote incentives and remove regulatory and market barriers that will help the industry grow and achieve the economies of scale. Another strategy is to help capture and disseminate operational best practices from Europe (Germany) and Asia (Japan) across the supply chain that will accelerate. 


\section{PV Value Case Studies and Scenarios}

We developed a variety of case studies that allowed for a consistent comparison of PV values for specific PV systems. Case studies in Texas, California, Minnesota, Wisconsin, Maryland, New York, Massachusetts, and Washington were reviewed. Seven of these case studies were residential systems and five were commercial systems. The case that had the most information was the Austin Energy study. Below are the results of the study for a 5-kilowatt $(\mathrm{kW})$ residential system. ${ }^{1}$ As Table E-3 illustrates, customer participants have a positive net present value (NPV) while utilities/ratepayers and society have a negative NPV in this example. It is important to note that in this case study, the central power capacity cost is low, compared to other studies. This is because the displaced marginal resource was a baseload gas turbine plant, while other studies consider peaking plants with limited hours of annual operation as the displaced marginal resource. Another value that is low compared to other studies is the T\&D cost savings because load growth is mostly occurring in suburban areas with a relatively low T\&D upgrade budget. Values that are taken from the case (either directly or indirectly) are highlighted in color.

Table E-3. PV Values for a 5-kW Residential System in Austin Energy Territory

\begin{tabular}{|c|c|c|c|c|c|}
\hline & PV Values & $\begin{array}{l}\text { Customer } \\
\text { Participant } \\
\text { (c/kWh }\end{array}$ & $\begin{array}{c}\text { Utility/ } \\
\text { Ratepayers } \\
\text { (C/kWh }\end{array}$ & Society $(C / k W h)$ & Net (e/kWh) \\
\hline \multirow{10}{*}{ है } & Central Power Generation Cost & - & 70 & . & 7.0 \\
\hline & Central Power Capacity Cost & $=$ & 1.1 & - & 1.1 \\
\hline & T\&:D Costs & - & 0.1 & - & 0.1 \\
\hline & System Loases & $=$ & 0.6 & - & 0.6 \\
\hline & Aneillary Services & & 0.8 & & 0.8 \\
\hline & Hedge Value & & $0.0^{\circ}$ & & 0.0 \\
\hline & Customer Price Protection & & 0.0 & & o.s \\
\hline & Criteria Pollutant Emissions & \multirow{3}{*}{ - } & \multirow{3}{*}{ - } & \multirow{3}{*}{$20^{* *}$} & \multirow{3}{*}{2.0} \\
\hline & Greenhouse Gas Emissions & & & & \\
\hline & Implseit Value & & & & \\
\hline \multirow{3}{*}{ 品 } & Equipment and Installation & $(29.3)$ & - & - & (30.6) \\
\hline & PV OscM Expenses & $(0.1)$ & - & $\cdot$ & (0.1) \\
\hline & Benefits Overhesd & $(0.2)$ & & & 10.23 \\
\hline \multirow{3}{*}{$\vec{d}$} & PV Owner Electricity Bull & 63 & (63) & . & $\cdot$ \\
\hline & Federal Incentives & 1.6 & - & (1.6) & - \\
\hline & State Incentives & 0.0 & $\cdot$ & 0.0 & $\cdot$ \\
\hline & Stakeholder Total & {$[20.9]$} & 3.3 & 0.4 & $(17.2)$ \\
\hline
\end{tabular}

Note: Values with negligible amounts excluded. Future values discounted at $8.25 \%$. Source: NCI analysis; The Value of Distributed Photovoltaics to Austin Energy and the City of Austin, Clean Power Research

Although there was incomplete information in each of the cases, we were able to use our model to provide reasonably accurate values for the missing information. In addition to the case studies, we created six scenarios that demonstrate the model capability. The scenarios are a PV system with storage, a PV system with demand response, a low

\footnotetext{
${ }^{1}$ Hoff, T.E., Perez, R., Braun, G., Kuhn, M., Norris, B., The Value of Distributed Photovoltaics to Austin Energy and the City of Austin, Clean Power Research LLC (March 17, 2006)
} 
installation and equipment cost scenario, a low installation and equipment cost scenario with no incentives, a $\$ 30 /$ ton GHG scenario and a $\$ 50 /$ ton GHG scenario.

\section{PV Value R\&D Recommendations}

It is recommended that NREL and DOE enhance their efforts to fund R\&D that will increase the magnitude and clarity of value from grid connected PV systems. More specifically:

Over the short term

- Promote a standard framework and develop tools easily available to industry to assess the value of PV systems.

- Take a leadership role in the development of a standard approach to value GHG and criteria pollutant emissions.

- Quantify the costs and benefits associated with integrating current and emerging energy storage systems and demand response applications with PV systems.

Over the midterm

- Collaborate with utilities in the development and deployment of new technologies and operating practices to increase the value captured by utilities and ratepayers from PV systems.

Over the long term

- Take a leadership role in establishing frameworks for long-term policies, regulations, and incentives that will reduce the risks and uncertainty currently limiting investment in PV markets.

To develop a standard framework and tools to quantify the value of PV systems, DOE should look at existing programs assessing the value of PV, such as the ones sponsored by the Massachusetts Technology Collaborative (MTC), Sacramento Municipal Utility District (SMUD), and Austin Energy, and identify the next R\&D steps for those programs. For example, the MTC is undertaking a pilot program to place a large amount of PV within a congested area of the grid to test the actual values of PV. DOE might consider offering to review the results and leverage some dollars to support the analysis of results and take next steps in funding follow-on R\&D. DOE can also support additional analyses of PV values within utility distribution networks, which the California Energy Commission is currently funding. In these cases, there were areas of contention, such as GHG emissions, the implicit value of PV, health benefits of emissions, T\&D capacity values, and storage and demand response that could benefit from additional analysis. Some studies had a conservative view of benefits while others had high expectations for the future.

In addition, DOE should collaborate with utilities in the development and deployment of new technologies and operating practices to increase the value captured by utilities and 
ratepayers from PV systems. These research efforts would help improve the value of grid connected PV systems, reach economic parity with traditional central generation options, and increase their market penetration. Table E-4 provides the most critical R\&D recommendations.

Table E-4. Selected PV Value R\&D Recommendations

\begin{tabular}{|c|c|}
\hline PV Value & R\&D Opportunities \\
\hline $\begin{array}{l}\text { Central Power } \\
\text { Capacity Cost }\end{array}$ & $\begin{array}{l}\text { - Generally improve the cost and performance of energy storage systems } \\
\text { - Understand how demand response can help PV systems displace central capacity }\end{array}$ \\
\hline $\begin{array}{l}\text { Central Power } \\
\text { Generation Cost }\end{array}$ & - Assess actual performance of installed PV systems against predicted performance \\
\hline T\&D Costs & $\begin{array}{l}\text { - Develop cost-effective monitoring control and validation for performance and physical assurance } \\
\text { - Develop tools for utilities to incorporate PV system output uncertainty into T\&D planning and capacity } \\
\text { deferment processes } \\
\text { - Research technical and economical feasibility to use smart grids to manage bidirectional power flows } \\
\text { from PV systems and plug-in hybrids }\end{array}$ \\
\hline $\begin{array}{l}\text { Greenhouse Gas } \\
\text { Emissions }\end{array}$ & - Launch a consensus based effort to standardize emissions valuation method. \\
\hline $\begin{array}{l}\text { Implicit Value } \\
\text { of PV }\end{array}$ & $\begin{array}{l}\text { - Use surveys/focus groups to understand motivations within each stakeholder group (e.g. consumers, } \\
\text { developers, utilities) behind PV projects that went ahead even with a negative net present value }\end{array}$ \\
\hline $\begin{array}{l}\text { System } \\
\text { Resiliency }\end{array}$ & $\begin{array}{l}\text { - Collect data from utilities or on a region-wide basis regarding number of hours of power outage and } \\
\text { assess which outage hours could have been avoided by the use of PV with distributed energy storage }\end{array}$ \\
\hline $\begin{array}{l}\text { Customer } \\
\text { Reliability }\end{array}$ & $\begin{array}{l}\text { - Assess the value of backup power for critical loads that can be provided by PV with distributed energy } \\
\text { storage for residential and commercial customer classes }\end{array}$ \\
\hline $\begin{array}{l}\text { Customer } \\
\text { Electric Price } \\
\text { Protection }\end{array}$ & - Develop an accepted methodology to value the certainty of fuel prices \\
\hline $\begin{array}{l}\text { Equipment and } \\
\text { Installation Cost }\end{array}$ & $\begin{array}{l}\text { - Compare technology requirements in Europe, Japan and the U.S. and assess the impact of codes on PV } \\
\text { system design and costs }\end{array}$ \\
\hline $\begin{array}{l}\text { Benefits } \\
\text { Overhead }\end{array}$ & $\begin{array}{l}\text { - Understand what data and infrastructure (e-g., meters, data management, remote controlling and } \\
\text { central monitoring) is required, and what it will take for utilities to rely on PV as a resource }\end{array}$ \\
\hline
\end{tabular}




\section{Table of Contents}

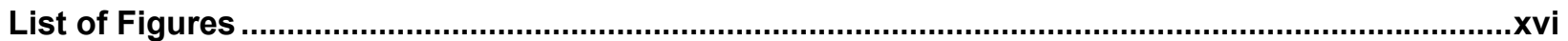

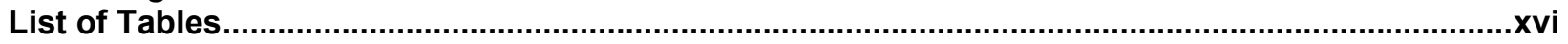

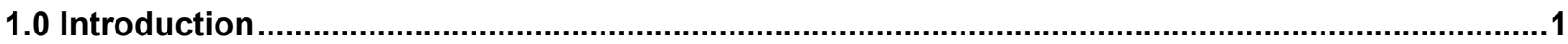

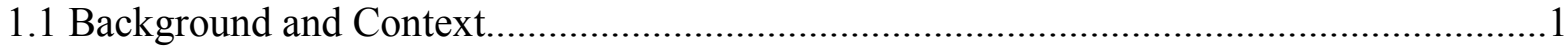

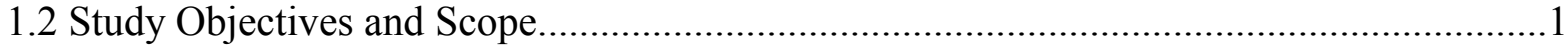

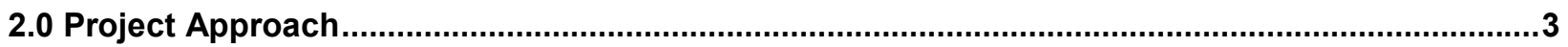

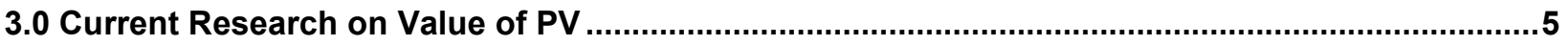

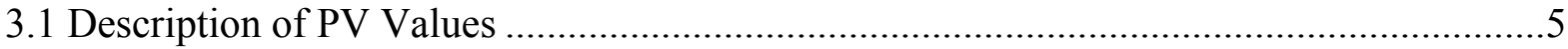

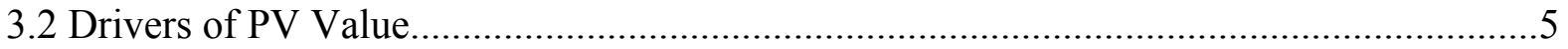

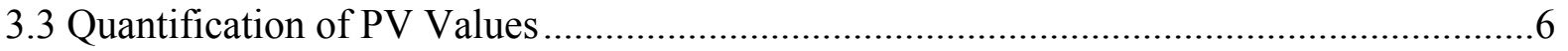

3.3.1 Central Power Generation Cost .......................................................................... 7

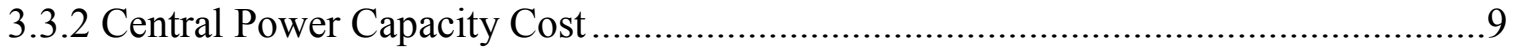

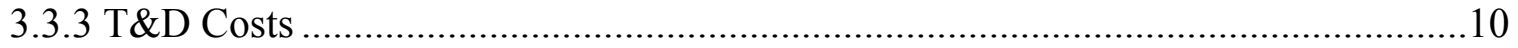

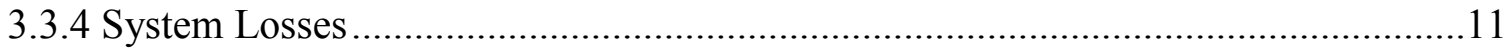

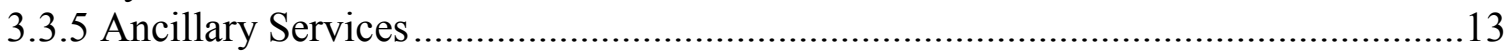

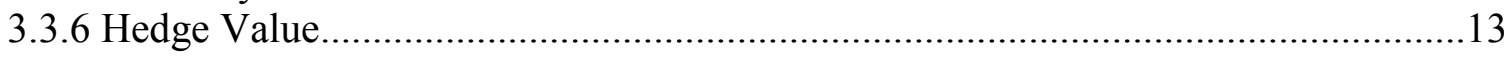

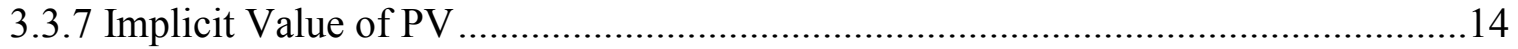

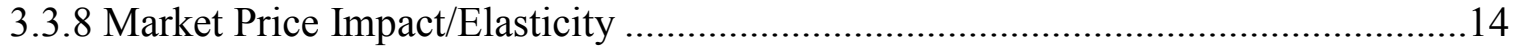

3.3.9 Customer Price Protection .............................................................................. 15

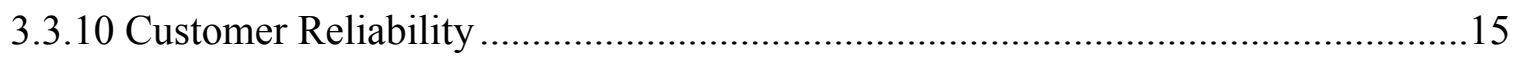

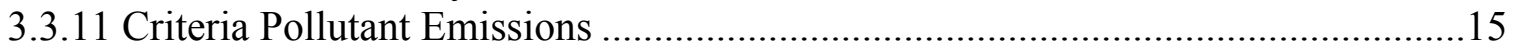

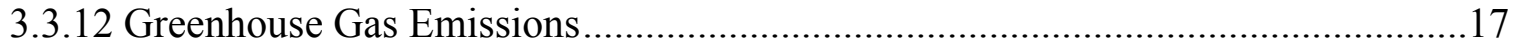

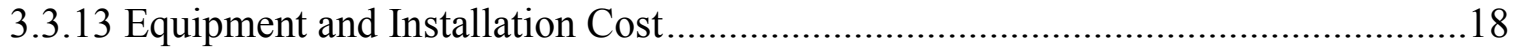

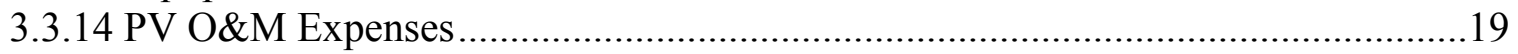

3.3.15 Benefits Overhead....................................................................................... 19

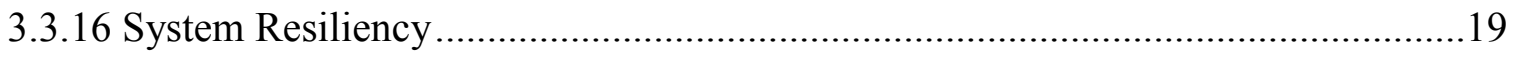

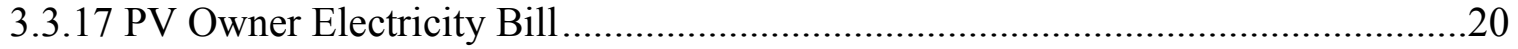

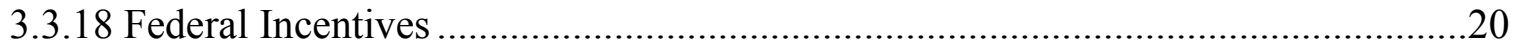

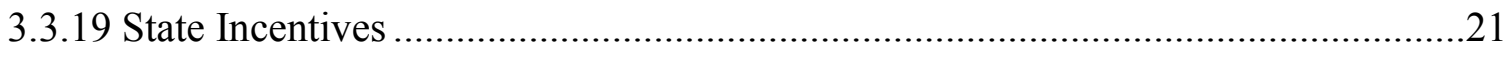

4.0 PV Value Case Studies and Scenarios.................................................................................22

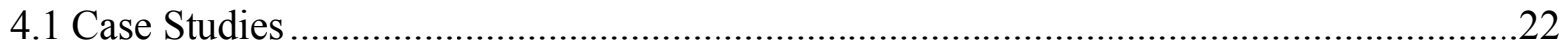

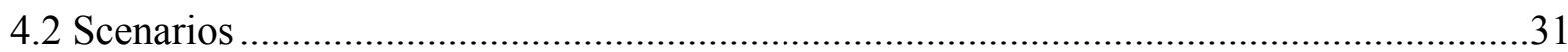

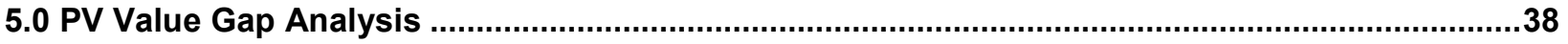

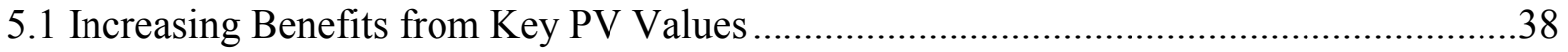

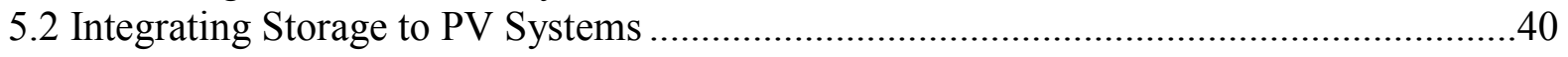

5.3 Integrating Demand Response with PV Systems ....................................................42

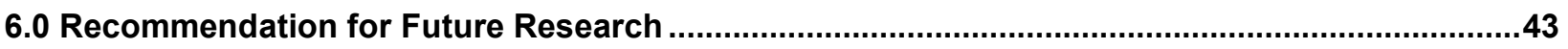

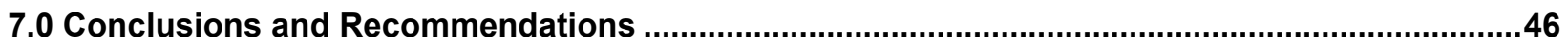

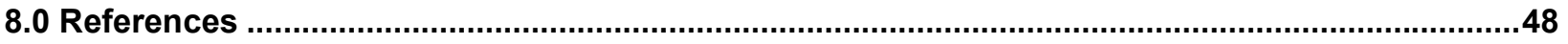




\section{List of Figures}

Figure E-1. Key Drivers of PV Values ........................................................................... ix

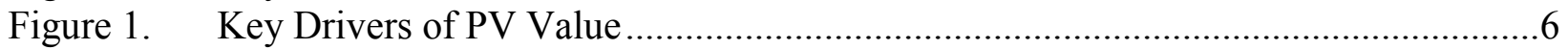

\section{List of Tables}

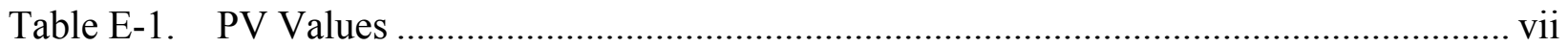

Table E-2. PV Values Ranges........................................................................................... viii

Table E-3. PV Values for a 5-kW Residential System in Austin Energy Territory .................. xii

Table E-4. Selected PV Value R\&D Recommendations ....................................................... xiv

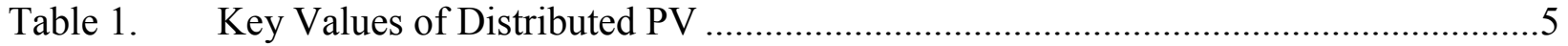

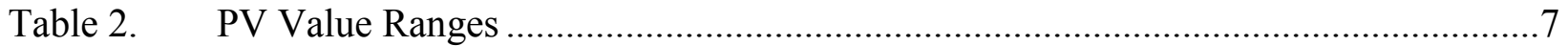

Table 3. Range and Drivers: Central Power Generation Cost .............................................

Table 4. Range and Drivers: Central Power Capacity Cost ....................................................10

Table 5. Range and Drivers: T\&D Costs ........................................................................1

Table 6. Range and Drivers: System Losses....................................................................12

Table 7. Range and Drivers: Ancillary Services.................................................................13

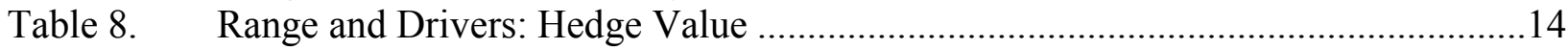

Table 9. Range and Drivers: Implicit Value of PV .................................................................

Table 10. Range and Drivers: Customer Price Protection .....................................................15

Table 11. Range and Drivers: Criteria Pollutant Emissions ……………………...................16

Table 12. $\quad$ Range and Values: Greenhouse Gas Emissions...................................................18

Table 13. Range and Drivers: Equipment and Installation .....................................................18

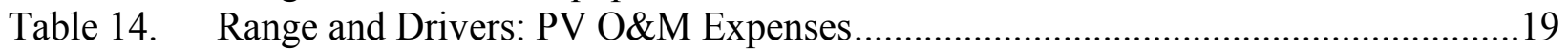

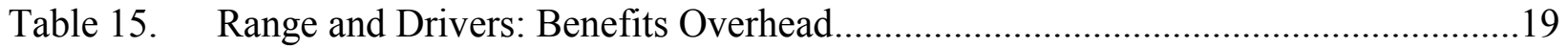

Table 16. Range and Drivers: PV Owner Electricity Bill ....................................................2

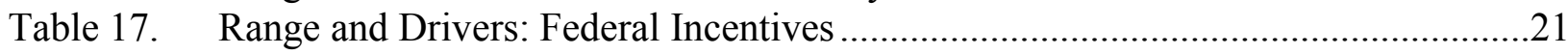

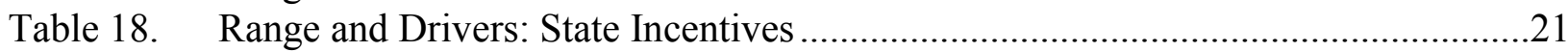

Table 19. Case 1 Summary Austin Energy Residential System ................................................23

Table 20. Case 2 Summary Austin Energy Commercial System ............................................23

Table 21. Case 3 Summary New Residential Home in Northfield, MN...................................24

Table 22. Case 4 Summary New Residential Home in Madison, WI.........................................25

Table 23. Case 5 Summary Existing Residential Home in Glenn Dale, MD ............................26

Table 24. Case 6 Summary Existing Commercial Building in Kingston, NY...........................27

Table 25. Case 7 Summary Existing Commercial Building in Cambridge, MA.......................28

Table 26. Case 8 Summary, Existing Municipal in Del Mar, CA ............................................29

Table 27. Case 9 Summary Existing Residential Home in Bellingham, WA.............................30

Table 28. Case 10 Summary Existing Residential Home in New York, NY ............................31

Table 29. Case 11 Summary Existing Commercial Building in New York, NY ......................31

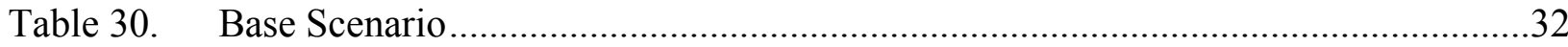

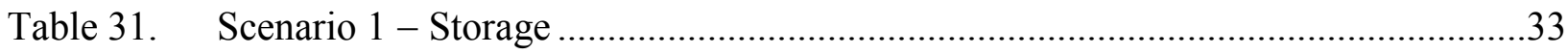

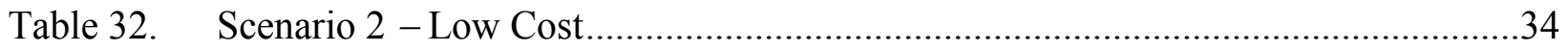

Table 33. Scenario 3 - Low Cost and No Incentives...........................................................35

Table 34. Scenario 4 - Greenhouse Gas Emissions at \$30/ton ............................................36

Table 35. Scenario 5 - Greenhouse Gas Emissions at \$50/ton ...............................................37

Table 36. Recommended R\&D to Increase the Value of Grid Interconnected PV ...................45 


\subsection{Introduction}

\subsection{Background and Context}

Due to accelerated cost reductions and associated growth in production, renewable energy technologies such as solar photovoltaics (PV) and wind are expected to grow rapidly in the United States during the next couple of decades. As these technologies mature they have the potential to provide a significant share of our nation's electricity demand.

However, as their market share grows, concern about potential impacts on the stability and operation of the electricity grid may create barriers to their future expansion. To overcome these potential barriers, the U.S. Department of Energy (DOE) launched the Renewable System Integration (RSI) Study. This study will address both the technical and analytical challenges that need to be tackled to enable high penetration levels of solar, wind, and other renewable energy technologies. Of particular interest are approaches that include comprehensive analyses that were used for decision making, rather than an academic study, because the ultimate goal is for stakeholder groups to make decisions on solar investment based on their understanding of the value to them.

By combining renewable technologies with storage, controls, and other appropriate technologies, the RSI Study will build the foundation for realizing a high penetration renewable energy future while enhancing the operation of the electricity grid. In addition, by directly engaging utilities and other stakeholders in this process, this study will build the confidence of regulators and utilities with respect to maximizing the use of renewable energy technologies.

Integrating renewable energy into the grid consists of two distinct elements, centralized renewable generation and distributed renewable generation. This study focuses on the distributed generation element that starts with solar photovoltaic (PV) technology that interconnects at the distribution level (less than $15 \mathrm{kV}$ ) to facilitate the widespread market penetration of renewable energy technologies, including storage systems, advanced power electronics, and controls into the U.S. electricity grid. The RSI study included 14 reports. This document represents one of the RSI reports, focused on quantifying the value of grid-connected PV.

\subsection{Study Objectives and Scope}

The purpose of the Value Analysis is to integrate the results of previous research on the value of distributed $\mathrm{PV}$ and define needs for additional R\&D. The report covers the following information:

- The various potential values of distributed PV, including the cost and benefits to participating customers, utilities/ratepayers, and society

- The best methodologies used for estimating key PV values

- A base case quantification and range for each key PV value 
- The gaps in existing knowledge and corresponding R\&D recommendations

- Case studies demonstrating value of distributed PV.

In addition to this report, a simple Microsoft ${ }^{\circledR}$ Excel-based tool has been developed to conduct sensitivity analyses around each key value. 


\subsection{Project Approach}

The project was divided into eight major tasks:

- Task 1: Analyze existing research PV values

- Task 2: Carry out case studies for PV values

- Task 3: Define PV values

- Task 4: Quantify ranges for PV values

- Task 5: Identify key value drivers

- Task 6: Identify gaps to increase value from PV

- Task 7: Define R\&D recommendations

- Task 8: Develop a simple Excel tool.

In Task 1, a comprehensive examination of the previous research related to the value of PV was performed. We included research reports from a wide range of sources, including internal NCI databases, NREL's PV Value Clearinghouse database, and other databases available on the internet. While some reports took a comprehensive and holistic approach and quantified a broad set of values, other reports focused on a single value and provided greater research depth for that single value. Section 8.0, References, lists the research reports that were reviewed for this report.

In Task 2, we identified existing case studies that quantified the value of a specific PV system installation. In addition to the sources listed above, we also looked for case studies with leading utilities, equipment manufacturers, and project developers. Unfortunately, most of the case studies quantified the PV values for a single stakeholder. In most cases, the stakeholder was either the participant customer installing a PV system on a roof or a utility that had a customer installing a PV system. We selected case studies with the most complete set of information and used our model to fill in missing values.

In Task 3, we integrated the previous research on the value of PV and defined a list of 19 PV values. This list provides a mutually exclusive and collectively exhaustive framework to assess the benefits and costs associated with grid connected PV systems. The preliminary list of values was presented to the RSI team during the July 26, 2007, interim presentation meeting. Input was received and incorporated into the final list of PV values.

In Task 4, we integrated existing research that quantified the PV values. Different methodologies used to quantify each of the values were documented. The range of magnitudes assigned to each value by the different research reports was also documented. The value ranges were assigned to key stakeholder groups (participant customer, utility/ratepayers, and society) either as a positive financial impact (benefit) or a negative financial impact (cost). The PV values with net positive financial impact across key stakeholders were classified as benefits, the PV values with net negative financial impact were classified as costs, and the PV values with net zero financial impact were classified as transfers. 
In Task 5, we summarized the key value drivers of PV. This task was performed by analyzing values with the highest magnitude and defining the variables that impacted each of those values. The similarities among the variables of the high magnitude values provided the bases for the key drivers.

In Task 6, we identified gaps to improve the value from PV systems. This task focused on finding opportunities to increase the benefits or reduce the costs of the highest magnitude PV values. Several strategies were identified for each of the highest magnitude PV values.

In Task 7, we defined opportunities for DOE and NREL to sponsor additional R\&D efforts to improve the quantification of PV values and/or improve the value captured from PV systems. With a few exceptions, most of the high magnitude PV values had well established methodologies to quantify the financial impacts, while some of the PV values with lower magnitude PV values do not have generally accepted methods. As a result, recommendations for improving the quantification centered on lower magnitude values. However, almost all values provided an opportunity to increase the benefits and reduce costs through additional R\&D. A preliminary list of R\&D opportunities by PV value was identified.

In Task 8, we developed a simple Excel tool to estimate the value of PV under different scenarios. The tool is based on the resulting quantification of values from existing research reports that was documented in Task 4 . The user inputs the utility that provides service to the customer installing the PV system, the type of customer, and a highmedium-low scenario for several of the PV values. The tool then creates an output table that quantifies the benefits and costs associated with each PV value to each of the key stakeholder groups (i.e., participant customer, utility/ratepayers, and society). A base case study was performed for both a representative residential and commercial Texas PV system. The purpose is to demonstrate the value of employing a comprehensive approach for assessing the value of distributed PV. The study also helps to understand and quantify the value that has led stakeholders to carry out projects with a negative NPV. 


\subsection{Current Research on Value of PV}

\subsection{Description of PV Values}

We began with a comprehensive list of quantitative and qualitative PV benefits and costs. After further discussion and collaboration with key stakeholder groups and industry experts, the list was narrowed for the purpose of this report to 19 mutually exclusive and collectively exhaustive values of distributed PV (Table 1).

Table 1. Key Values of Distributed PV

\begin{tabular}{|c|c|}
\hline PV Value & Description \\
\hline $\begin{array}{l}\text { Central Power Generation } \\
\text { Cost }\end{array}$ & $\begin{array}{l}\text { PV systems produce electricity, reducing the amount of electricity that needs to be generated } \\
\text { at other plants, which in turn decreases fuel and other O\&M costs. }\end{array}$ \\
\hline $\begin{array}{l}\text { Central Power Capacity } \\
\text { Cost }\end{array}$ & $\begin{array}{l}\text { PV indirectly avoids and/or defers central power plant capacity investments by reducing } \\
\text { demand-side consumption. Generation capacity value is the economic value of the avoided } \\
\text { and/or deferred incremental resource (typically natural gas turbine) reflecting PV's peak } \\
\text { load reduction. NIMBY opposition and higher construction costs are driving capacity costs } \\
\text { up. PV also avoids the cost of running more expensive plants during peak loads. }\end{array}$ \\
\hline T\&D Cost & $\begin{array}{l}\text { PV avoids and/or defers transmission and distribution capacity investments by reducing } \\
\text { demand-side consumption. Transmission and distribution capacity value is the economic } \\
\text { value of the avoided and/or deferred incremental resource reflecting PV's peak load } \\
\text { reduction. NIMBY opposition and higher construction costs are driving capacity costs up. } \\
\text { This value is also applicable to situations involving significant congestion issues. }\end{array}$ \\
\hline System Losses & $\begin{array}{l}\text { Avoided electric system losses are an indirect benefit because they increase the value of other } \\
\text { benefits including energy production, generation capacity, environmental and T\&D capacity. }\end{array}$ \\
\hline Ancillary Services & $\begin{array}{l}\text { Utilities can use inverters in PV systems to provide reactive power back to the grid. This } \\
\text { increases power quality and could avoid the installation of capacitors. }\end{array}$ \\
\hline System Resiliency & $\begin{array}{l}\text { Significant deployment of PV systems coupled with storage could provide disaster recovery } \\
\text { benefits. }\end{array}$ \\
\hline Hedge Value & $\begin{array}{l}\text { Current electricity generation is heavily dependant on natural gas and coal. Recent } \\
\text { environmental constraints suggest that utilities will become more dependent on natural gas. } \\
\text { PV lessens the exposure of the utility to volatile fuel prices and provides stable and } \\
\text { predictable electricity prices. }\end{array}$ \\
\hline $\begin{array}{l}\text { Market Price } \\
\text { Impacts/Elasticity }\end{array}$ & $\begin{array}{l}\text { The elasticity of demand for electricity supply increases with more PV. Increased demand } \\
\text { for PV may decrease the price of electricity from PV, spur market development, thereby } \\
\text { further reducing the cost of PV. A decrease in the cost may then increase the demand for } \\
\text { this lower cost good. }\end{array}$ \\
\hline $\begin{array}{l}\text { Customer Electricity Price } \\
\text { Protection }\end{array}$ & $\begin{array}{l}\text { Since there is no fuel expense, the costs of electricity from PV will not increase over the life of } \\
\text { the system due to fuel costs and the consumer effectively locks in an electricity price. }\end{array}$ \\
\hline Customer Reliability & $\begin{array}{l}\text { PV can provide electricity to the PV owner during outages because it is not dependent on the } \\
\text { grid. The electricity during an outage is limited to sunlight availability. Storage systems } \\
\text { could help offset the intermittency issue and increase the reliability value to the owner. }\end{array}$ \\
\hline $\begin{array}{l}\text { Criteria Pollutant } \\
\text { Emissions }\end{array}$ & $\begin{array}{l}\mathrm{PV} \text { systems eliminate criteria pollutant emissions (e.g., } \mathrm{NO}_{x}, \mathrm{SO}_{\mathrm{x}} \text { ) associated with non- } \\
\text { renewable generation resources. Health benefits associated with reduced emissions are } \\
\text { included in this value. }\end{array}$ \\
\hline $\begin{array}{l}\text { Greenhouse Gas } \\
\text { Emissions }\end{array}$ & $\begin{array}{l}\text { PV systems eliminate greenhouse gases }\left(\mathrm{CO}_{2}\right) \text { associated with non-renewable generation } \\
\text { resources. Renewable Portfolio Standards (RPS) and Renewable Energy Certificates (REC's) } \\
\text { are common mechanisms to value emission reductions from renewable sources of energy } \\
\text { such as PV. }\end{array}$ \\
\hline Implicit Value of PV & $\begin{array}{l}\text { The intrinsic societal value of PV to customers (e.g., environmental friendliness, feeling } \\
\text { good, early adopter) and utilities (e.g., public relations, regulator compliance). }\end{array}$ \\
\hline
\end{tabular}

\subsection{Drivers of PV Value}

The two main drivers for the highest magnitude values are location of the PV system and timing of the power output of the system. As illustrated in Figure 1, a PV system will have higher benefits when it is located in a highly congested distribution system, where there is high insolation to increase production of the PV system, and where gas prices are high. PV systems will also have higher benefits when a large share of their production is 
during peak demand periods, and when PV systems displace expensive peaking plants that have lower efficiency and utilization, and use more expensive fuel.

Figure 1. Key Drivers of PV Value

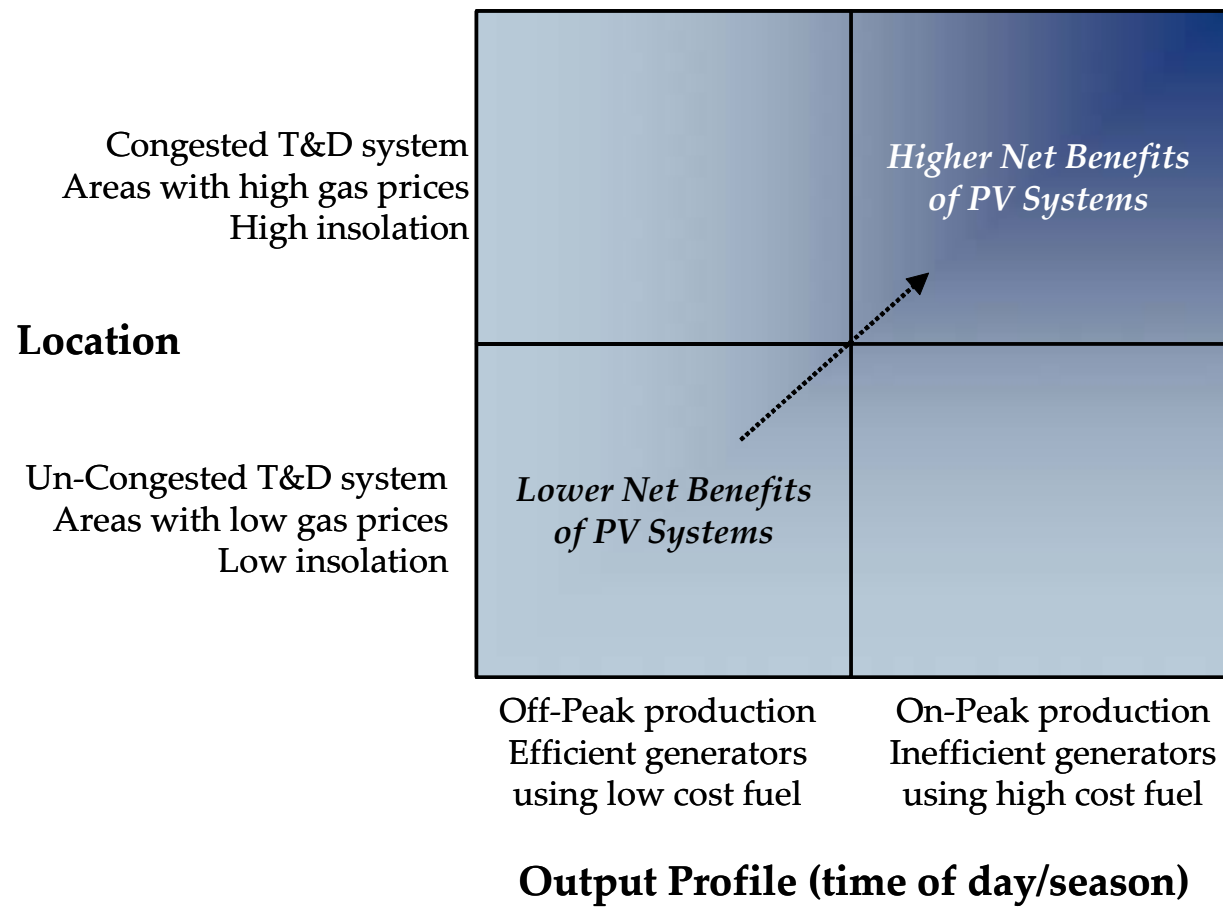

\subsection{Quantification of PV Values}

PV values were quantified and allocated to several categories of stakeholders: customer participant, utilities/ratepayers and society. Customer participants take the perspective of PV system owners and end-users. Utilities/ratepayers represent all electric utility customers in the region. Finally, society represents the general population.

We defined a range for each value, because PV values have multiple drivers that can cause values to vary across the United States. The high end of the range corresponds to the high values found in the literature search. Our perception is that this value corresponds to the $90^{\text {th }}$ percentile because there will be isolated situations where true values may be even higher. In a similar fashion, the low end of the range corresponds to the low end of values found in the literature search, representing a value in the $10^{\text {th }}$ percentile because of the isolated situations where values may be even lower. A summary of each value and range along with the driving factors for each value is presented below. 
Table 2. PV Value Ranges

\begin{tabular}{|c|c|c|c|c|c|c|}
\hline & PV Values & $\begin{array}{c}\text { Customer } \\
\text { Particlpant } \\
\text { (G/kWh) }\end{array}$ & $\begin{array}{c}\text { Utility/ } \\
\text { Ratepayers } \\
\text { (E/kWh) }\end{array}$ & $\begin{array}{l}\text { Socieby } \\
\text { (e/kWhi }\end{array}$ & $\begin{array}{l}\text { Net } \\
(\mathbb{C} / \mathbf{k W h})\end{array}$ & Value Divers \\
\hline \multirow{13}{*}{ 罵 } & Central Power Generation Cost & & $3.2-9.7$ & & $3.2-9.7$ & Gas price, heat rate \\
\hline & Central Power Capacity Cost & & $1.1-10.6$ & & $1.1-10 . s$ & $\begin{array}{l}\text { Effective load carrying capacity factor, gas } \\
\text { turbine captral cost, life adjustment }\end{array}$ \\
\hline & T\&D Costs & & $01-100$ & & $0.1-10.0$ & Location, growth, elimate \\
\hline & System Loses & & $0.5-4.3$ & & $0.5-4.3$ & Location, time period, other benefits \\
\hline & Ancillary Services & & $0-1.5$ & & $0-1.5$ & Ancillary service prices, voltage support \\
\hline & System Restliency & & Low & & Low & Quantification methodology unclear \\
\hline & Hedge Value & & $0-0.9$ & & $0-0.9$ & Gas price forecasts, futures, heat rate \\
\hline & Market Price Lmpacts/Elasticity & & Low & & Low & Quantification methodology unclear \\
\hline & Customer Price Protection & $0.5-10$ & & & $0.5-1.0$ & Caleulation method \\
\hline & Customer Reliability & Low & & & Low & Quantification methodology unclear \\
\hline & Criteria Pollutant Emissions & & & $0.02-20$ & $0.02-20$ & Market value of emiseions \\
\hline & Greenhouse Gas Emiasions & & & $0.02-42$ & $0.02-4.2$ & $\begin{array}{l}\text { Reduction costs, market value, discount } \\
\text { rate }\end{array}$ \\
\hline & Implicit Value of PV & & & $0-20$ & $0-2.0$ & Customer wrilingness to pay premium \\
\hline \multirow{3}{*}{ 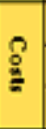 } & Equipment and Installation & $(47)-(19)$ & & & $(47)-(19)$ & Size, location \\
\hline & PV O\&M Expenses & $(0.15)-(0.05)$ & & & $(0.15)-(0.05)$ & Type of system \\
\hline & Benefits Overhead & & $(0.2)-(0.1)$ & & $10.21-10.1)$ & Infrastructure and administrative costs \\
\hline \multirow{3}{*}{$\frac{1}{3}$} & PV Owner Electricity Bill & $11-330$ & $(330)-(1.1)$ & & - & Customer type, rate structure, lond protile \\
\hline & Federal Incentives & $1.50-7.95$ & & $(7.95)-(1.50)$ & - & Customer type, size, cap \\
\hline & State Incentives & $0-178$ & & $(178)-0$ & - & State, customer type, size, production, cap \\
\hline \multicolumn{2}{|r|}{ Stakeholder Total } & $(4397)-407$ & $(28.3)-36.0$ & $(257)-6.6$ & $(41.9)-27.3$ & \\
\hline
\end{tabular}

The remainder of this section discusses the drivers for each PV value in more detail and the methodology and assumptions used to calculate each value.

\subsubsection{Central Power Generation Cost}

Methodology 1: External Market Pricing

Marginal Cost of Electricity Generation (cents $/ \mathrm{kWh}$ ) = Natural Gas Cost for Power Plants $(\$ /$ MBtu $) \times 100 \times$ Heat Rate for Natural Gas Power Plants $(B t u / k W h) / 1,000,000+$ O\&M Costs (cents/kWh). ${ }^{2}$

The methodology for this value uses the avoided cost of natural gas (NG) and in some cases variable O\&M costs to determine avoided generation costs. NG costs can be derived by multiplying NG futures contract prices on the New York Mercantile Exchange (NYMEX) by an assumed heat rate. The NYMEX range $(\$ 4.570$ to $\$ 8.752 / \mathrm{MBtu})$ is used extensively for $\mathrm{NG}$ prices ${ }^{3,4,5}$.

\footnotetext{
${ }^{2}$ Futures price data can be obtained at http://www.nymex.com/markets/newquotes.cfm and other natural gas information can be obtained at http://tonto.eia.doe.gov/oog/info/ngw/ngupdate.asp.

${ }_{3}^{3}$ Americans for Solar Power (ASPv), Build-Up of PV Value in California (April 13, 2005)

${ }^{4}$ Energy and Environmental Economics, Inc. and Rocky Mountain Institute, Methodology and Forecast of Long Term Avoided Costs for the Evaluation of California Energy Efficiency Programs (October 25, 2004)

${ }^{5}$ Itron, Inc. CPUC Self-Generation Incentive Program Preliminary Cost-Effectiveness Evaluation Report,

(September 14, 2006)
} 
The Vote Solar White Paper ${ }^{6}$, a study consisting of various service regions in California, uses a different approach. At the high end of the range the price of NG during the California energy crisis $(\$ 8.05 / \mathrm{MBtu})$ is used, while at the low end the average NYMEX price $(\$ 6.49 / \mathrm{kWh})$ is used. In most studies, heat rates in the range of $7,100 \mathrm{Btu} / \mathrm{kWh}$ to $11,100 \mathrm{Btu} / \mathrm{kWh}$ are used. In the Navigant MTC report, it was found the average heat rate is $\$ 7,000 \mathrm{Btu} / \mathrm{kWh} .^{7}$ The Vote Solar White Paper uses a range of heat rates that vary depending on the age of the power plant fleet and the time of use. Non-peak power plants vary from $8,740 \mathrm{Btu} / \mathrm{kWh}$ to $9,690 \mathrm{Btu} / \mathrm{kWh}$ while a nominal rate of $9,390 \mathrm{Btu} / \mathrm{kWh}$ is used for peak power plants.

The Duke, et al. study ${ }^{8}$ estimates O\&M costs at less than a cent $/ \mathrm{kWh}$ while the Vote Solar white paper estimates O\&M costs to be 1.1 cents/kWh. The ASPv report values avoided variable $O \& M$ costs from 0.01 cent $/ \mathrm{kWh}$ to 0.14 cent $/ \mathrm{kWh}$. The Vote Solar White Paper values avoided natural gas costs from 5.6 cents/kWh (PG\&E) to 6.3 cents/kWh (SDG\&E \& SCE) for non-peak generation under the electric utility scenario (9.5\% cost of capital with 20 -year recovery period). Non-peak, generation-avoided natural gas values range from 7.6 cents/kWh to 8.5 cents/kWh under the merchant power plant developer scenario ( $15 \%$ cost of capital with 10 -year recovery period). The on-peak generation values are 6.6 cents $/ \mathrm{kWh}$ under the electric utility scenario and 8.0 cents $/ \mathrm{kWh}$ under the merchant power plant scenario. (These values did not vary depending on the service region.) The range for the Rocky Mountain Institute ${ }^{4}$ study, which also analyzes the California region, is 6.5 cents $/ \mathrm{kWh}$ to 8.0 cents $/ \mathrm{kWh}$. The ASPv report values the avoided cost of natural gas from 3.2 cents/kWh to 9.7 cents $/ \mathrm{kWh}$.

Some reports simply use a utility's internal marginal cost to forecast its avoided central power plant generating cost. The marginal cost is usually adjusted to reflect current natural gas prices (using NYMEX). The Austin Energy Report ${ }^{9}$ and the SMUD Report ${ }^{10}$ use this approach. The Austin Energy Report yielded a range of 7.0 cents/kWh to 7.2 cents/kWh.

\footnotetext{
${ }^{6}$ Smellof E., Quantifying the Benefits of Solar Power for California (January 2005)

${ }^{7}$ Navigant Consulting Inc., Distributed Generation and Distribution Planning: An Economic Analysis for the Massachusetts DG Collaborative (February 12, 2006)

${ }^{8}$ Duke, Richard, Robert Williams and Adam Payne, Accelerating Residential PV Expansion: Demand Analysis for Competitive Electricity Markets (2004),

${ }^{9}$ Hoff, T.E., Perez, R., Braun, G., Kuhn, M., Norris, B., The Value of Distributed Photovoltaics to Austin Energy and the City of Austin, Clean Power Research LLC, (March 17, 2006)

${ }^{10}$ Hoff, T.E, Final Results Report with a Determination of Stacked Benefits of Both Utility-Owned and Customer-Owned PV Systems, Clean Power Research, L.L.C (2002)
} 
Table 3. Range and Drivers: Central Power Generation Cost

\begin{tabular}{|c|c|c|}
\hline Range of Value & Net $(\mathbb{C} / \mathbf{k W h})$ & Drivers \\
\hline $\begin{array}{l}\text { High End of Range ( } 90 \% \\
\text { percentile) }\end{array}$ & 9.7 & $\begin{array}{l}\text { - NG Price variance: The high end of the range of NG } \\
\text { futures contract prices on the NYMEX ( } \$ 8.75 / \mathrm{MMBtu}) \text {, } \\
\text { the California energy crisis average of } \$ 8.05 / \mathrm{MMBtu}{ }^{1} \text {. } \\
\text { Prices also vary by region - MA had a price of } \\
\$ 9.10 / \mathrm{MMBtu} \text { in } 2005^{2} \text {. The low end of natural gas futures } \\
\text { contract prices on the NYMEX ( } \$ 4.57 / \mathrm{MMBtu}) \text { is } \\
\text { generally used as the low end of the range. } \\
\text { - Heat Rate variance: Different areas have different heat } \\
\text { rates depending on the age of the fleet }-9,720 \mathrm{Btu} / \mathrm{kWh}\end{array}$ \\
\hline $\begin{array}{l}\text { Low End of Range ( } 10 \% \\
\text { percentile) }\end{array}$ & 3.2 & $\begin{array}{l}\text { newer fleet in MA that has an average heat rate of } 7,000 \\
\text { Btu/kWh }{ }^{1,2} \text {. } \\
\text { - Capital Cost Recovery Factor variance: high end is } \\
\text { merchant power plant ( } 15 \% \text { capital cost over a } 10 \mathrm{yr} \text {. } \\
\text { period) and low end is electric utility }(9.5 \% \text { capital cost } \\
\text { over } 20 \text { yr. period })^{1} \text {. }\end{array}$ \\
\hline
\end{tabular}

\footnotetext{
Smellof E., Quantifying the Benefits of Solar Power for California (January 2005) http://www.votesolar.org/tools QuantifyingSolar\%27sBenefits.pdff

Navigant Consulting Inc., Distributed Generation and Distribution Planning: An Economic Analysis for the Massachusetts DG Collaborative (February 12 , 2006)

Hoff, T.E., Perez, R., Braun, G., Kuhn, M., Norris, B., The Value of Distributed Photovoltaics to Austin Energy and the City of Austin, Clean Power Research LLC, (March 17, 2006) http://www.austinenergy.com/About\%20Us/Newsroom/Reports/PV-ValueReport.pdf
}

\subsubsection{Central Power Capacity Cost}

\section{Methodology 1: Economic and Technical Analysis}

Central Power Plant Capacity $($ cents $/ \mathrm{kWh})=$ Capital Cost $(\$ / \mathrm{kW}) \times 100 \times$ ELCC Factor $\times$ Levelization Factor

\section{Levelization Factor $=$ Discount Factor $\mathrm{x}$ Annual Energy}

The levelization factor is used to convert cents $/ \mathrm{kW}$ to cents $/ \mathrm{kWh}$ and is critical in the analysis. The discount rate and hours of energy generation must be estimated. The economic analysis involves determining a capacity value, which is assumed to be either a gas peaking turbine or a combined-cycle gas turbine in most studies. The capital costs vary from $\$ 419 / \mathrm{kW}$ to $\$ 619 / \mathrm{kW}^{11}$. Values for other reports fell into this range. The effective capacity of PV is the effective contribution it provides to the available generation capacity of the utility. The Effective Load Carrying Capacity (ELCC) factor is widely used to determine how much of the PV capacity can contribute to alleviate utility peak loads. This factor is dependant on the region and orientation of the photovoltaic cells. The Vote Solar White Paper ${ }^{12}$ uses an ELCC factor of $50 \%$ for the region of California while the ASPv Report ${ }^{13}$ uses 65\%. The Austin Energy Report uses an ELCC range of $47 \%$ to $62 \%$ depending on the orientation of the PV cells ${ }^{14}$. A study conducted by NREL shows 20 utility service areas have matches to load shapes ranging from $36-70 \%$. The range for the Vote Solar White Paper ${ }^{13}$ was 6.2 cents/kWh to 10.8 cents/kWh.

\footnotetext{
${ }^{11}$ Americans for Solar Power (ASPv), Build-Up of PV Value in California (April 13, 2005)

${ }^{12}$ Smellof E., Quantifying the Benefits of Solar Power for California (January 2005)

${ }^{13}$ Americans for Solar Power (ASPv), Build-Up of PV Value in California (April 13, 2005)

${ }^{14}$ Hoff, T.E., Perez, R., Braun, G., Kuhn, M., Norris, B., The Value of Distributed Photovoltaics to Austin Energy and the City of Austin, Clean Power Research LLC, (March 17, 2006)
} 


\section{Methodology 2: Life Adjustment Factor}

Central Power Plant Capacity $($ cents $/ \mathrm{kWh})=$ Capital Cost $(\$ / \mathrm{kW}) \times 100 \times$ ELCC Factor

$\times$ Levelization Factor $\times$ Life Adjustment Factor

Life Adjustment Factor $=[$ GT Life $(y r s)-P V$ Life (yrs) $] /[$ GT Life $(y r s)] \times$ $\left(1 /(1+\text { Discount Rate })^{\wedge} 25\right)$

This method includes a life adjustment factor. It accounts for the fact that on average the life of a gas turbine is 40 years and the life of a PV system is 30 years. In the Austin Energy Report a $7 \%$ discount factor is used, and a $25 \%$ salvage value is used for the GT, resulting in a 3.3\% longer life for the $\mathrm{GT}^{14}$. The range for the Austin Energy Report ${ }^{15}$ is 1.1 cents $/ \mathrm{kWh}$ to 1.8 cents $/ \mathrm{kWh}$.

Table 4. Range and Drivers: Central Power Capacity Cost

\begin{tabular}{|c|c|c|}
\hline Range of Value & Net ( $\mathbb{c} / \mathbf{k W h})$ & Drivers \\
\hline $\begin{array}{l}\text { High End of Range ( } 90 \% \\
\text { percentile) }\end{array}$ & 10.8 & \multirow{2}{*}{$\begin{array}{l}\text { - ELCC Factor: High end occurs when peak load coincides } \\
\text { with high solar availability. NREL conducted an analysis } \\
\text { for } 20 \text { utilities and found } 70 \% \text { at the high end }{ }^{1}-\text { ASPV used } \\
65 \%^{2} \text { while Ed Smellof was close to the low end at } 50 \% \text {. } \\
\text { - Orientation of PV: The AE Report looked at how different } \\
\text { orientations affected the ELCC and found a range of } 47 \% \\
\text { (west at } 45 \mathrm{deg} \text { ) to } 62 \% \text { ( } 1 \text { axis at } 30 \mathrm{deg})^{3} \text {. } \\
\text { - Capital Cost of NG Turbine: Varies depending on region, } \\
\text { in California it was assumed to be } \$ 515 / \mathrm{kW} \text { while in } \\
\text { Austin it was assumed to be } \$ 475 \text {. } \\
\text { - Life Adjustment Factor: Most studies did not account for } \\
\text { this except for the Austin Energy Report. This increased } \\
\text { the value of the gas turbine by } 1.033 \text {. }\end{array}$} \\
\hline $\begin{array}{l}\text { Low End of Range ( } 10 \% \\
\text { percentile) }\end{array}$ & 1.1 & \\
\hline
\end{tabular}

1. Smellof E., Quantifying the Benefits of Solar Power for California (January 2005) http://www.votesolar.org/tools_QuantifyingSolar\%27sBenefits.pdf

2. Americans for Solar Power (ASPv), Build-Up of PV Value in California (April 13, 2005) http://www.mtpc.org/renewableenergy/public policy/DG/resources/2005-04-CA-PV-Value-Links-R04-03-017.pdf

3. Hoff, T.E., Perez, R., Braun, G., Kuhn, M., Norris, B., The Value of Distributed Photovoltaics to Austin Energy and the City of Austin, Clean Power Research LLC, (March 17, 2006) http://www.austinenergy.com/About\%20Us/Newsroom/Reports/PV-ValueReport.pdf

\subsubsection{T\&D Costs}

\section{Methodology 1: T\&D Growth Method}

Deferred T\&D Capital Cost Value (cents/kWh) $=[($ Cost of T\&D Investment Plan $(\$) \times$ $100 \times$ Value of Money $(\%) \times$ ELCC Factor $) /$ Load Growth] $\times$ Levelization Factor

Although this value includes both transmission and distribution, there are cases that are specific to one or the other. For example, PV can be installed in an area that reduces the transmission peak but is in a distribution area with excess capacity, thus providing limited value. The cost of the T\&D investment plan comprises a number of different values such as feeder upgrade deferral, transformer lifetime increase, reduced load-tap changer/voltage regular use, etc.

${ }^{15}$ Ibid 
Deferred T\&D costs depend heavily on the ELCC factor and growth in the region. The ELCC method is used extensively in studies. In the Austin Energy Report ${ }^{16}$ the ELCC factor varied between $46 \%$ and $63 \%$ depending on the orientation, while the Rocky Mountain Institute Report ${ }^{17}$ and the Vote Solar White Paper ${ }^{18}$ used nominal rates of $65 \%$ and 50\% respectively. Annual growth ranges from 0.5 megawatts per year (MW/yr) to 12.3 MW/yr for the Austin Energy Report, while the Vote Solar White Paper assumes a constant growth rate independent of the region of $5 \%$.

Ideal resource values range from $\$ 39 / \mathrm{kW}$ to $\$ 445 / \mathrm{kW}$ for the Austin Energy Report based on region. The Rocky Mountain Institute Report also breaks up the costs by climate zone and region, from $\$ 39 / \mathrm{kW}$ to $\$ 88 / \mathrm{kW}$ for the Vote Solar White Paper and from $\$ 9 / \mathrm{kW}$ to $\$ 88 / \mathrm{kW}$ for the Rocky Mountain Institute Report. The Austin Energy Report yields a levelized cost range of 0.1 cents $/ \mathrm{kWh}$ to 0.2 cents $/ \mathrm{kWh}$. The Rocky Mountain Institute White Paper report yields a levelized cost range of 4.5 cents $/ \mathrm{kWh}$ to 10 cents/kWh. The high value generally applies to situations where there are high T\&D costs with good load match.

Table 5. Range and Drivers: T\&D Costs

\begin{tabular}{|c|c|c|}
\hline Range of Value & 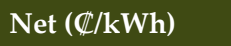 & Drivers \\
\hline $\begin{array}{l}\text { High End of Range }(90 \% \\
\text { percentile) }\end{array}$ & 10 & \multirow[b]{2}{*}{$\begin{array}{l}\text { - Location: Urban areas, such as downtown Austin } \\
(\$ 445 / \mathrm{kW})^{1}, \text { have more expensive T\&D upgrade } \\
\text { costs, whereas areas such as rural California have } \\
\text { cheaper T\&D upgrade costs }(\$ 9 / \mathrm{kW})^{2} \text {. } \\
\text { - Temperature: Regions where temperature spikes } \\
\text { dramatically, T\&D avoided costs are high, } \\
\text { whereas in coastal regions with moderate } \\
\text { temperatures, T\&D costs are lower (i.e. East Bay - } \\
\$ 9.25 / \mathrm{kW})^{2} \text {. } \\
\text { - Growth: Projected load growth varies. In } \\
\text { downtown Austin growth is small }(0.4 \mathrm{MW} / \mathrm{yr}) \\
\text { while in the Southwest it's } 12.3 \mathrm{MW} / \mathrm{yr} . \\
\text { - Location \& Growth: Areas where there is high } \\
\text { growth and high costs of T\&D upgrades are at the } \\
\text { high end, whereas areas where they don't coincide } \\
\text { (such as Austin) are on the low end. }\end{array}$} \\
\hline $\begin{array}{l}\text { Low End of Range (10\% } \\
\text { percentile) }\end{array}$ & 0.1 & \\
\hline
\end{tabular}

1. Hoff, T.E., Perez, R., Braun, G., Kuhn, M., Norris, B., The Value of Distributed Photovoltaics to Austin Energy and the City of Austin, Clean Power Research LLC, (March 17, 2006) http://www.austinenergy.com/About\%20Us/Newsroom/Reports/PV-ValueReport.pdf

2. Energy and Environmental Economics, Inc. (E3) and Rocky Mountain Institute, Methodology and Forecast of Long Term Avoided Costs for the Evaluation of California Energy Efficiency Programs (October 25, 2004) http://www.ethree.com/cpuc/E3 Avoided Costs Final.pdf

3. Smellof E., Quantifying the Benefits of Solar Power for California (January 2005) http://wwww.votesolar.org/tools_QuantifyingSolar\%27sBenefits.pdf

\subsubsection{System Losses}

\section{Methodology 1: Loss Factors}

Avoided Costs with Line Losses $($ cents $/ \mathrm{kWh})=($ Avoided Generation Capacity Costs + Avoided Energy Production Costs + Avoided T\&D Costs + Avoided Environmental Costs $) \times($ Loss Factor -1$)$

\footnotetext{
${ }^{16}$ Hoff, T.E., Perez, R., Braun, G., Kuhn, M., Norris, B., The Value of Distributed Photovoltaics to Austin Energy and the City of Austin, Clean Power Research LLC, (March 17, 2006)

${ }^{17}$ Energy and Environmental Economics, Inc. and Rocky Mountain Institute, Methodology and Forecast of Long Term Avoided Costs for the Evaluation of California Energy Efficiency Programs (October 25, 2004)

${ }^{18}$ Smellof E., Quantifying the Benefits of Solar Power for California (January 2005)
} 
PV reduces system losses by producing power at the point of consumption - it is an indirect benefit because it magnifies the value of other benefits. Methodology 1 uses an approach by performing the calculations twice - with and without loss impacts. Taking the difference between the two provides an explicit value for this benefit.

Studies such as the Vote Solar White Paper ${ }^{19}$ estimate loss factors for each benefit. The Austin Energy Report ${ }^{20}$ describes three different methods of calculating the loss factor: calculating the system average (Total Electricity Loss/Total Electricity Produced), the incremental change in losses that occur during peak loads and the incremental changes in losses that occur over all hours in the time period. The latter is the method used by the SMUD Report ${ }^{21}$. The Navigant MTC Report found that electrical system losses in the T\&D system alone are $2 \%$ to $6 \%{ }^{22}$. In some studies all of the categories are grouped together under one factor. In the Austin Energy Report the various categories were split up. The report found that the greatest loss savings were in energy production followed by generation capacity, environmental, and T\&D. In the Austin Energy Report the loss savings benefit ranged from 0.6 cents $/ \mathrm{kWh}$ to 0.7 cents $/ \mathrm{kWh}$. The Vote Solar White Paper has a range of 0.7 cents $/ \mathrm{kWh}$ to 2.6 cents $/ \mathrm{kWh}$ while the ASPv report has a range of 0.52 cents $/ \mathrm{kWh}$ to 1.36 cents $/ \mathrm{kWh}$. The Duke et al. Report has a loss value of 4.3 cents $/ \mathrm{kWh}$.

\section{Methodology 2: Credit}

This is an implicit method that credits the PV system to account for the reduction in losses. Each value calculation is performed using the higher $\mathrm{kW}$ or $\mathrm{kWh}$ figures. None of the studies investigated use this method because it does not provide an explicit number.

Table 6. Range and Drivers: System Losses

\begin{tabular}{|c|c|c|}
\hline Range of Value & Net $(\mathbb{C} / \mathbf{k W h})$ & Drivers \\
\hline High End of Range ( $90 \%$ percentile) & 4.3 & \multirow[b]{2}{*}{$\begin{array}{l}\text { System Location: The loss factor is dependant on the } \\
\text { location. The further away from the power plant, the } \\
\text { higher the loses. Some utility systems have higher average } \\
\text { loses than others (i.e. SDG\&E } 8 \% \text { vs. PG\&E } 9 \%)^{1} \text {. } \\
\text { Time Period: The magnitude of loss factors is dependant } \\
\text { on the time period that electricity is produced (i.e. peak } \\
\text { vs. non-peak). SDG had } 11 \% \text { during peak and } 8 \% \text { during } \\
\text { non-peak. }{ }^{1} \\
\text { Type of Benefit: The impact of loss savings varies for } \\
\text { each value. Generation savings are impacted the most (i.e. } \\
9 \% \text { vs. T\&D } 7.4 \%)^{2}\end{array}$} \\
\hline Low End of Range ( $10 \%$ percentile) & 0.5 & \\
\hline Smellof E., Quantifying the Benefits of Solar $P$ & r California (Janu & 2005) http:///wwww.votesolar.org/tools_QuantifyingSolar\%27sBenefits.pdf \\
\hline $\begin{array}{l}\text { Energy and Environmental Economics, Inc. } \\
\text { California Energy Efficiency Programs (Octobe }\end{array}$ & & $\begin{array}{l}\text { Institute, Methodology and Forecast of Long Term Avoided Costs for the Evaluation of } \\
\text { ree.com/cpuc/E3_Avoided_Costs_Final.ppff }\end{array}$ \\
\hline
\end{tabular}

\footnotetext{
${ }^{19}$ Smellof, E., Quantifying the Benefits of Solar Power for California (January 2005)

${ }^{20}$ Hoff, T.E., Perez, R., Braun, G., Kuhn, M., Norris, B., The Value of Distributed Photovoltaics to Austin Energy and the City of Austin, Clean Power Research LLC, (March 17, 2006)

${ }^{21}$ Hoff, T.E, Final Results Report with a Determination of Stacked Benefits of Both Utility-Owned and Customer-Owned PV Systems, Clean Power Research, L.L.C (2002)

${ }^{22}$ Navigant Consulting Inc., Distributed Generation and Distribution Planning: An Economic Analysis for the Massachusetts DG Collaborative (February 12, 2006)
} 


\subsubsection{Ancillary Services}

\section{Methodology 1: Utility Bill Analysis}

Ancillary Services include: VAR Support, load following, operating reserves, and dispatch and scheduling. The distributed generation (DG) units are unlikely or unable to participate in the markets for load following, operating reserves, and dispatch and scheduling. Although unlikely to participate in the market, synchronous DG may provide some of these services when operating. The potential value of ancillary services to other electric ratepayers for PV used in the Rocky Mountain Institute Report ${ }^{23}$ is valued at the CAISO market price range of 0.5 to 1.5 cents/kWh. The Vote Solar White Paper ${ }^{24}$ values ancillary services at 0.2 cents $/ \mathrm{kWh}$. The Austin Energy Report ${ }^{25}$ evaluates the voltage regulation benefit by assuming that $\mathrm{PV}$ inverters could be modified to operate at the desired power factor. The results suggest that although there is a range depending on how much the PV system can be depended on for voltage support, the value will always be close to 0 cents $/ \mathrm{kWh}$. The MTC report by NCI values ancillary services at 0.3 cents/kWh, based on the E3 Report. ${ }^{26}$

Table 7. Range and Drivers: Ancillary Services

\begin{tabular}{|c|c|c|}
\hline Range of Value & Net $(₫ / \mathbf{k W h})$ & Drivers \\
\hline High End of Range (90\% percentile) & 1.5 & -Ancillary Service Prices \\
\hline Low End of Range ( $10 \%$ percentile) & - & - Perceived reliability for voltage support. \\
\hline
\end{tabular}

\subsubsection{Hedge Value}

\section{Methodology 1: Guarantee Electricity Supply Costs}

Natural gas hedge value $(\$ / \mathrm{kWh})=$ Cost to guarantee that a portion of electricity supply costs are fixed $(\$ / \mathrm{kWh})$

The value equals the cost of natural gas futures discounted at the risk-free discount rate. This analysis requires the natural gas price over the life of the PV system and the risk free discount rate associated with each year of the analysis. The Austin Energy Report uses NYMEX natural gas futures prices and the U.S. Treasury Yield Curve for risk free discounts rates. (The London Interbank Offer Rate (LIBOR) could also be used.) The Austin Energy Report had a discount factor of 0.96 in 2007 and 0.27 in 2035. The ASPv report values of the price hedge from 0.4 to 0.9 cents $/ \mathrm{kWh}$.

\footnotetext{
${ }^{23}$ Energy and Environmental Economics, Inc. and Rocky Mountain Institute, Methodology and Forecast of Long Term Avoided Costs for the Evaluation of California Energy Efficiency Programs (October 25, 2004)

${ }^{24}$ Smellof E., Quantifying the Benefits of Solar Power for California (January 2005)

${ }^{25}$ Hoff, T.E., Perez, R., Braun, G., Kuhn, M., Norris, B., The Value of Distributed Photovoltaics to Austin Energy and the City of Austin, Clean Power Research LLC, (March 17, 2006)

${ }^{26}$ Navigant Consulting Inc., Distributed Generation and Distribution Planning: An Economic Analysis for the Massachusetts DG Collaborative (February 12, 2006)
} 


\section{Methodology 2: Selling Risk Free Benefits}

Natural gas hedge value $(\$ / \mathrm{kWh})=$ Price that entity will pay for risk-reduction benefits $(\$ / \mathrm{kWh})$. Another method mentioned in the Austin Energy Report to value the PV is to sell natural gas futures (or other contracts) in proportion to natural gas savings from PV.

Table 8. Range and Drivers: Hedge Value

\begin{tabular}{|c|r|c|}
\hline Range of Value & Net $(\mathbb{C} / \mathbf{k W h})$ & Drivers \\
\cline { 1 - 2 } High End of Range (90\% percentile) & 0.9 & $\begin{array}{l}\text { ・ Market Stability: A volatile market creates more value } \\
\text { for a hedge while stable market prices decrease this } \\
\text { value. }\end{array}$ \\
Low End of Range (10\% percentile) & 0.0 & Heat Rates: Low efficiency heat rates increase the value. \\
\hline
\end{tabular}

1. Wiser, R., Mills, A., Barbose, G., Golove, W., The Impact of Retail Rate Structures on the Economics of Commercial Photovoltaic Systems in California (July 2007), Lawrence Berkeley National Laboratory http://eetd.lbl.gov/ea/ems/reports/63019.pdf

\subsubsection{Implicit Value of PV}

\section{Methodology 1: Market Data}

Most of the studies analyzed do not have methodologies for determining the intrinsic value of PV. However, the Austin Energy Report ${ }^{27}$ examined market data that indicates customer willingness to pay premium prices for green power and found that it had a value of 2 cents $/ \mathrm{kWh}$. There are other reports available that analyze green market pricing and EPRI is currently conducting work in this area.

Table 9. Range and Drivers: Implicit Value of PV

\begin{tabular}{|c|c|c|}
\hline Range of Value & Net $(\mathbb{C} / \mathbf{k W h})$ & Drivers \\
\hline High End of Range ( $90 \%$ percentile) & 2 & \multirow{2}{*}{$\begin{array}{l}\text { - Customer willingness to pay premium for } \\
\text { green power. }^{1}\end{array}$} \\
\hline Low End of Range ( $10 \%$ percentile) & 0 & \\
\hline
\end{tabular}

1. Hoff, T.E., Perez, R., Braun, G., Kuhn, M., Norris, B., The Value of Distributed Photovoltaics to Austin Energy and the City of Austin, Clean Power Research LLC, (March 17, 2006) http://www.austinenergy.com/About\%20Us/Newsroom/Reports/PV-ValueReport.pdf

\subsubsection{Market Price Impact/Elasticity Methodology 1: Long-Term Supply Curve}

The Rocky Mountain Institute Report ${ }^{28}$ and the California Public Utilities Commission Report $^{29}$ were some of the only studies that recognized that reduced demand results in a decrease in the market-clearing price for electricity, and therefore an increase in consumer surplus. However, it was found that this benefit is likely to be small and does not cause a price decrease. Most studies did not try to quantify this value because there are so many factors influencing natural gas demand.

\footnotetext{
${ }^{27}$ Hoff, T.E., Perez, R., Braun, G., Kuhn, M., Norris, B., The Value of Distributed Photovoltaics to Austin Energy and the City of Austin, Clean Power Research LLC, (March 17, 2006)

${ }^{28}$ Energy and Environmental Economics, Inc. and Rocky Mountain Institute, Methodology and Forecast of Long Term Avoided Costs for the Evaluation of California Energy Efficiency Programs (October 25, 2004)

${ }^{29}$ Energy and Environmental Economics, Inc. and Rocky Mountain Institute, Methodology and Forecast of Long Term Avoided Costs for the Evaluation of California Energy Efficiency Programs (October 25, 2004)
} 


\subsubsection{Customer Price Protection}

\section{Methodology 1: Market Based}

Electricity Price Risk Mitigation $=E R F-E R(E R F=$ Cost of Electricity from Risk-Less

Generation Asset, ER = Cost of Electricity from Risky Portfolio)

This method consists of calculating the cost of electricity from the risky portfolio and the cost of electricity from the risk-less generation asset and taking the difference. The SMUD Report ${ }^{30}$ found this method to yield a premium of $0.5 \mathrm{cents} / \mathrm{kWh}$. (Natural gasfired generation firmed up with natural gas futures is assumed to be the least cost riskfree generation asset).

\section{Methodology 2: CAPM}

Electricity Price Risk Mitigation $=(E P-y E R) /(1-y)-E R$

$(\mathrm{EP}=$ Cost of Electricity from District Portfolio, $\mathrm{y}=$ percent of the risky portfolio)

This alternative approach solves for the expected cost of the risk-less asset as shown above. The SMUD Report found this method to yield a premium of 1.0 cents $/ \mathrm{kWh}$.

Table 10. Range and Drivers: Customer Price Protection

\begin{tabular}{|l|r|l|}
\hline \multicolumn{1}{|c|}{ Range of Value } & Net $(\mathbb{C} / \mathbf{k W h})$ & \multicolumn{1}{c|}{ Drivers } \\
\hline High End of Range (90\% percentile) & 1 & $\begin{array}{l}\text { Calculation Method: Method of determining } \\
\text { the value of the risk-less generation. }\end{array}$ \\
\hline Low End of Range (10\% percentile) & 0.5 & \\
\hline
\end{tabular}

\subsubsection{Customer Reliability}

Most of the studies evaluated do not quantify the value of customer reliability. However, several reports by LBNL and NREL look at the benefit of increased outage support for customers using batteries. ${ }^{31,32}$ The PV without storage provides little reliability, but with storage it would be worth in the range of 0 to 2.7 cents $/ \mathrm{kWh}$ depending on the reliability needs of the customer.

\subsubsection{Criteria Pollutant Emissions Methodology 1: Direct Cost Savings Emissions Benefit $(\$ / \mathrm{kWh})=$ Market Value of Penalties or Costs $(\$ / \mathrm{kWh})$}

There are two main methods of assigning an economic value: direct cost savings (penalties or costs to meet standards) and human health benefits. The majority of studies that do evaluate the economic benefits of emissions use the direct costs savings method $^{33,34,35}$. The connection between pollution and emission factors (lb/MBtu) is

\footnotetext{
${ }^{30}$ Hoff, T.E, Final Results Report with a Determination of Stacked Benefits of Both Utility-Owned and Customer-Owned PV Systems, Clean Power Research, L.L.C (2002)

${ }^{31}$ Hoff, T.E., Perez, R., Braun, Margolis, R.M., Maximizing the Value of Customer-Sited PV Systems Using Storage and Controls (2005)

${ }^{32}$ Hoff, T.E., Perez, R., Margolis, R.M., Increasing the Value of Customer-Owned PV Systems Using Batteries (November 9, 2004)

${ }^{33}$ Smellof E., Quantifying the Benefits of Solar Power for California (January, 2005)
} 
calculated by the U.S. Environmental Protection Agency (EPA) or CEC in most studies. The E3 Report ${ }^{29}$ uses South Coast Air Quality Management District (SCAQMD) Reclaim Data, CARB or Utility Planning Documents to come up with Emission Reduction Credits (ERCs) or RECLAIM Trading Credits (RTCs) resulting in an environmental value of 0.7 cents/kWh. The Austin Energy Report ${ }^{36}$ does not have an RPS mandate so a typical market-based green power program of 2.0 cents $/ \mathrm{kWh}$ is used. RPS requirements force electric service providers to either acquire/build renewable-generated electricity or to purchase RECs from others. The SMUD Report ${ }^{37}$ uses emissions costs based on the Sacramento Metropolitan Air Quality Management District (SMAQMD) credit banking system which sells emissions permits.

\section{Methodology 2: Health Benefits}

Emissions Benefit $(\$ / \mathrm{kWh})=$ Health Benefits to Society $(\$ / \mathrm{kWh})$

This method assigns the avoided health costs and shortened life times due to emissions as the value. This is difficult as the connection between emissions and health is not well established and there are no widely accepted methodologies. ${ }^{38}$ The ASPv paper states a range of health benefits from 0.02 cents $/ \mathrm{kWh}$ to 0.04 cents $/ \mathrm{kWh}$, while the Vote Solar White Paper reports a value of 1.4 cents/kWh for NOx emissions. A comprehensive study for the EPA also estimates the health effects (mortality, hospital admissions, bronchitis, work lost days, etc.) due to exposure to particulates from power plants. The report includes detailed methodologies and assumptions, but does not provide an overall levelized $\operatorname{cost}^{39}$.

Table 11. Range and Drivers: Criteria Pollutant Emissions

\begin{tabular}{|c|c|c|}
\hline Range of Value & Net $(\mathbb{C} / \mathbf{k W h})$ & Drivers \\
\hline High End of Range ( $90 \%$ percentile) & 0.02 & \multirow{2}{*}{$\begin{array}{l}\text { Market Value (government mandate, } \\
\text { geographic region): Some areas place a } \\
\text { high market value on emission } \\
\text { reductions such as California while and } \\
\text { others do not, such as Austin. }\end{array}$} \\
\hline Low End of Range ( $10 \%$ percentile) & 2.0 & \\
\hline
\end{tabular}

\footnotetext{
${ }^{34}$ Energy and Environmental Economics, Inc. and Rocky Mountain Institute, Methodology and Forecast of Long Term Avoided Costs for the Evaluation of California Energy Efficiency Programs (October 25, 2004)

${ }^{35}$ Hoff, T.E., Perez, R., Braun, G., Kuhn, M., Norris, B., The Value of Distributed Photovoltaics to Austin Energy and the City of Austin, Clean Power Research LLC (March 17, 2006)

${ }^{36}$ Hoff, T.E., Perez, R., Braun, G., Kuhn, M., Norris, B., The Value of Distributed Photovoltaics to Austin

Energy and the City of Austin, Clean Power Research LLC, (March 17, 2006)

${ }^{37}$ Hoff, T.E, Final Results Report with a Determination of Stacked Benefits of Both Utility-Owned and Customer-Owned PV Systems, Clean Power Research, L.L.C (2002)

${ }^{38}$ Hoff, T.E., Perez, R., Braun, G., Kuhn, M., Norris, B., The Value of Distributed Photovoltaics to Austin Energy and the City of Austin, Clean Power Research LLC, (March 17, 2006)

${ }^{39}$ ABT Associates and ICF Consulting The Particulate-Related Health Benefits of Reducing Power Plant Emissions, Prepared for Cleat Air Task Force, (October 2000)
} 


\subsubsection{Greenhouse Gas Emissions Methodology 1: Cost-Based Approach \\ $\mathrm{CO}_{2}$ Emission Benefit $(\$ / \mathrm{kWh})=$ Emission Intensity (tonnes of $\left.\mathrm{CO}_{2} / \mathrm{kWh}\right) \mathrm{x}$ (Value of \\ $\mathrm{CO}_{2}$ Emissions (\$/tonne)}

Although there are several methods to assign value to the GHG emissions (carbon tax, cap-and-trade programs, or REC trading), most studies used compliance costs. The emissions factor varies depending on the type of electricity generation. The E3 Report ${ }^{40}$ uses two values to justify a projection of the value of $\mathrm{CO}_{2}$ reductions. One is the shortterm price of $\$ 5 /$ ton of $\mathrm{CO}_{2}$ based on World Bank, Dutch, and UK market activity. The other is U.S. compliance with Kyoto protocol, which would result in a cost of $\$ 17.5 /$ ton of $\mathrm{CO}_{2}$ in 2013.

By discounting the projected stream of the shorter-term $\$ 5 /$ ton of $\mathrm{CO}_{2}$ at $8.15 \%$ to $\$ 17.5 /$ ton of $\mathrm{CO}_{2}$ in 2013 , the resulting present value is $\$ 8 /$ ton of $\mathrm{CO}_{2}$ (or $\$ 29 /$ ton of carbon). This results in a range of 0.33 cents $/ \mathrm{kWh}-0.52$ cents $/ \mathrm{kWh}$ based on the heat rate range of 7,100 to $11,100 \mathrm{Btu} / \mathrm{kWh}$. The Navigant MTC report found a value of $\$ 6.5 /$ ton for "very high emission" projections. ${ }^{41}$ A European Commission study detailed the costs of achieving reductions in GHG emissions and found the value to be $\$ 66$ to $\$ 170$ per ton of carbon. ASPv and Duke adopted the mid-range of this cost $(\$ 100 /$ ton of carbon) resulting in a range of 1.1 cents $/ \mathrm{kWh}$ to 1.8 cents $/ \mathrm{kWh} .{ }^{42,43}$ The Vote Solar Initiative White Paper ${ }^{44}$ uses the midpoint ( $\$ 92 /$ ton of carbon), which results in a benefit of 1.9 cents $/ \mathrm{kWh}$. The SMUD Report ${ }^{45}$ uses a range from $\$ 2.19$ (The Climate Trust) to $\$ 10$ per ton of $\mathrm{CO}_{2}$ (British Petroleum). If the United States passes the Low Carbon Economy Act, a price of $\$ 12$ per ton of $\mathrm{CO}_{2}$ will be implemented in 2012. This will result in a range of levelized costs from 0.2 to 1.0 cents $/ \mathrm{kWh}$ (using Navigant's model of emission intensity rates). The range of values is based on a $\$ 1 /$ ton scenario and a $\$ 50 /$ ton scenario and the emission intensity per state.

\footnotetext{
${ }^{40}$ Energy and Environmental Economics, Inc. and Rocky Mountain Institute, Methodology and Forecast of Long Term Avoided Costs for the Evaluation of California Energy Efficiency Programs (October 25, 2004)

${ }^{41}$ Navigant Consulting Inc., Distributed Generation and Distribution Planning: An Economic Analysis for the Massachusetts DG Collaborative (February 12, 2006)

${ }^{42}$ Americans for Solar Power (ASPv), Build-Up of PV Value in California (April 13, 2005)

${ }^{43}$ Duke, Richard, Robert Williams and Adam Payne, Accelerating Residential PV Expansion: Demand Analysis for Competitive Electricity Markets (2004)

${ }^{44}$ Smellof E., Quantifying the Benefits of Solar Power for California (January 2005)

${ }^{45}$ Hoff, T.E, Final Results Report with a Determination of Stacked Benefits of Both Utility-Owned and Customer-Owned PV Systems, Clean Power Research, L.L.C (2002)
} 
Table 12. Range and Values: Greenhouse Gas Emissions

\begin{tabular}{|c|c|c|}
\hline Range of Value & Net $(\mathbb{C} / \mathbf{k W h})$ & Drivers \\
\hline High End of Range ( $90 \%$ percentile) & 4.18 & \multirow{2}{*}{$\begin{array}{l}\text { - Carbon Value: High carbon value yields higher } \\
\text { value. } \\
\text { - Emissions Rates (location/efficiency of plant): } \\
\text { Higher carbon emission intensity yield higher value. } \\
\text { - Short \& Long Term Costs: Long term costs are } \\
\text { higher resulting in a larger benefit. } \\
\text { - Discount Rates:: The EC used low a discount rate, 1- } \\
\text { 3\%, resulting in higher avoided CO2 emissions } \\
\text { value'. } \\
\text { - Market or Cost Based Approach: Market based } \\
\text { approach yields higher results. }\end{array}$} \\
\hline Low End of Range ( $10 \%$ percentile) & 0.02 & \\
\hline
\end{tabular}

1. Smellof E., Quantifying the Benefits of Solar Power for California (January 2005) http://wwww.votesolar.org/tools QuantifyingSolar\%27sBenefits.pdf

\subsubsection{Equipment and Installation Cost \\ Methodology 1: Levelized Costs \\ Cost of Equipment $($ cents $/ \mathrm{kWh})=($ Capital Cost $($ cents $/ \mathrm{kW})+$ Fixed O\&M (cents/kW-yr) $)$ \\ $\times$ Levelized Cost Factor}

Levelized Cost Factor $=$ Cost of Equipment $/$ (Life of System $x$ DC-AC Conversion Factor x Capacity Factor x Annual Hours)

An NREL assessment uses costs provided by Black and Veatch: $\$ 3,600$ to $\$ 8,050 / \mathrm{kW}$ capital costs, $\$ 5.7$ to $\$ 8.2 / \mathrm{kW}$-yr fixed costs resulting in a levelized cost range of 19.4 to 47 cents/kWh. A study by Center for Sustainable Energy (CSE) ${ }^{46}$ found that without incentives the cost for a project in New York City was 50.17 cents $/ \mathrm{kWh}$. A breakdown of the costs estimates that $60 \%$ of the cost is the PV module, $25 \%$ balance of system, and $15 \%$ system design and installation. It is assumed that costs decrease at a rate of $5 \% / \mathrm{yr}^{47}$ We estimate current capital costs at 26.49 cents/kWh to 29.26 cents/kWh and project them to decrease to 17.79 cents/kWh to 18.98 cents/kWh by 2015 (in 2006 dollars). Our assumptions were 8,760 operating hours, a capacity factor of $15 \%$, a DC-AC conversion factor of 0.77 and a life of 25 years. We assumed that costs decreased annually by $4 \%$ to $6 \%$.

Table 13. Range and Drivers: Equipment and Installation

\begin{tabular}{|l|r|l|}
\hline \multicolumn{1}{|c|}{ Range of Value } & Net ( $\mathbf{c} / \mathbf{k W h})$ & \multicolumn{1}{c|}{ Drivers } \\
\hline High End of Range (90\% percentile) & $(19)$ & $\begin{array}{l}\text { Size: Large systems have inherently less cost on a per } \\
\text { kW basis than small systems. } \\
\text { Location: Labor costs vary significantly in different } \\
\text { regions (i.e. higher in NY) } \\
\text { Long Term Costs: The amount that costs will decrease } \\
\text { in future years can vary. }\end{array}$ \\
Low End of Range (10\% percentile) & $(47)$ \\
$1 . \quad \begin{array}{l}\text { Centre for Sustainable Energy at Bronx Community College, New York City's Solar Energy Future (January 2006) } \\
\text { http://www.bcc.cuny.edu/InstitutionalDevelopment/CSE/Documents/CUNY\%20MSR\%20-\%20Market\%20for\%20PV\%20in\%20NYC.pdf }\end{array}$
\end{tabular}

\footnotetext{
${ }^{46}$ Center for Sustainable Energy at Bronx Community College, New York City’s Solar Energy Future (January 2006)

${ }^{47}$ Del Chiaro, B., Dutzik, T., Vasavada, J., The Economics of Solar Homes in California, Environment California Research and Policy Center (December, 2004)
} 


\subsubsection{PV O\&M Expenses Methodology 1: Projected Costs}

Most studies assume these costs are negligible. Some other reports assume a variable cost, but it is extremely small (i.e., NREL: 0.05 to 0.15 cents/kWh). Inverters could have an impact and are currently replaced every 7 to 15 years.

Table 14. Range and Drivers: PV O\&M Expenses

\begin{tabular}{|l|r|l|}
\hline \multicolumn{1}{|c|}{ Range of Value } & Net $(\mathbb{\leftrightarrow} / \mathbf{k W h})$ & \multicolumn{1}{c|}{ Drivers } \\
\hline High End of Range $\mathbf{9 0} \%$ percentile) & $(0.15)$ & \multirow{2}{*}{ Type of System } \\
\cline { 1 - 2 } Low End of Range (10\% percentile) & $(0.05)$ & \\
\hline
\end{tabular}

\subsubsection{Benefits Overhead}

\section{Methodology 1: Comparable Incentive Programs}

Benefits Overhead $(\$)=$ Benefits Overhead Costs $(\$ / \mathrm{kW}) \times \mathrm{PV} \mathrm{kW}$

Benefits Overhead Costs are those associated with capturing and monetizing all of the various value streams. This includes program administration and other equipment costs, such as advanced metering and/or the cost to address technical issues for including PV in a distribution deferral solution. The program administration (salaries, facilities, program design, and implementation) and program evaluation costs (for hiring meter installation subcontractors) in California's Self-Generation Incentive Program are $\$ 12.5$ million. If allocated equally on a per $\mathrm{kW}$ basis across all active and complete projects, the cost is equal to $\$ 47.75 / \mathrm{kW}$. ${ }^{48}$ Using our assumptions, this is converted to 0.2 cents $/ \mathrm{kWh}$.

Table 15. Range and Drivers: Benefits Overhead

\begin{tabular}{|c|c|c|}
\hline Range of Value & Net $(₫ / \mathbf{k W h})$ & Drivers \\
\hline High End of Range ( $90 \%$ percentile) & $(0.2)$ & \multirow{2}{*}{$\begin{array}{l}\text { Rate Structure: Alters the PV value by } 25 \% \text { to } 75 \% \\
\text { depending on size of the PV system relative to the } \\
\text { building load }{ }^{1} \text {. } \\
\text { Customer Load Profile: Customers that peak in the } \\
\text { afternoon can receive significant demand charge savings } \\
\text { while facilities with flat or inverted profiles will earn } \\
\text { minimal demand charge reduction }{ }^{1} \text {. } \\
\text { PV Production Profile: At } 2 \% \text { penetration, range is } \$ 0.10- \\
0.18 / \mathrm{kWh} 0 \text { ) while at } 75 \% \text { penetration, range is } \$ 0.06- \\
0.18 / \mathrm{kWh})^{1}\end{array}$} \\
\hline Low End of Range ( $10 \%$ percentile) & $(0.1)$ & \\
\hline
\end{tabular}

\subsubsection{System Resiliency}

Few studies evaluated reliability in relation to disaster recovery. Currently, with or without storage, a PV system will trip off-line if the grid goes down. However, as engineering and procedural issues improve, $\mathrm{PV}$ combined with storage could provide disaster recovery relief. The Austin Energy Report ${ }^{49}$ valued this benefit by estimating the

\footnotetext{
${ }^{48}$ Energy and Environmental Economics, Inc. and Rocky Mountain Institute, Methodology and Forecast of Long Term Avoided Costs for the Evaluation of California Energy Efficiency Programs (October 25, 2004) ${ }^{49}$ Hoff, T.E., Perez, R., Braun, G., Kuhn, M., Norris, B., The Value of Distributed Photovoltaics to Austin Energy and the City of Austin, Clean Power Research LLC, (March 17, 2006)
} 
disaster cost, disaster propensity, and solar emergency power. Without storage the value was found to be negligible $(\$ 0 / \mathrm{kWh})$. The Austin Energy Report suggests that with significant deployment of storage this benefit could have substantial value.

\subsubsection{PV Owner Electricity Bill}

Methodology 1: Utility Bill Analysis

Electricity Bill Savings $(\$ / \mathrm{kWh})=($ Total Bill Without PV - Total Bill With PV $) /($ Annual Energy PV Production)

Rate structure, system size, orientation and degradation are all factors that impact savings. The Lawrence Berkeley National Laboratory (LBNL) Report ${ }^{50}$ shows that the value of PV systems varied immensely across customers and retail rates: 5 to 24 cents $/ \mathrm{kWh}$. Our model has a range of 1.1 cents $/ \mathrm{kWh}$ to 33.0 cents $/ \mathrm{kWh}$. The high end value is in California for residential customers on tiered rates. The range in the following table is based on our model.

Table 16. Range and Drivers: PV Owner Electricity Bill

\begin{tabular}{|c|c|c|}
\hline Range of Value & Net $(\mathrm{C} / \mathbf{k W h})$ & Drivers \\
\hline High End of Range $(90 \%$ percentile) & 33.0 & \multirow{2}{*}{$\begin{array}{l}\text { Rate Structure: Alters the PV value by } 25 \% \text { to } 75 \% \\
\text { depending on size of the PV system relative to the building } \\
\text { load. } \\
\text { Customer Load Profile: Customers that peak in the } \\
\text { afternoon can recesve sagnificant demand charge saving: } \\
\text { while facilities with flat or nnverted profiles will earn } \\
\text { munumal demand charge reduction. } \\
\text { PV Production Profile: At } 2 \% \text { penetration, range is } \$ 0.10 \text { - } \\
0.18 / \mathrm{kWh} 0 \text { ) while at } 75 \% \text { penetration, range is } \$ 0.06- \\
0.18 / \mathrm{kWh})^{1}\end{array}$} \\
\hline Low End of Range ( $10 \%$ percentile) & 1.1 & \\
\hline
\end{tabular}

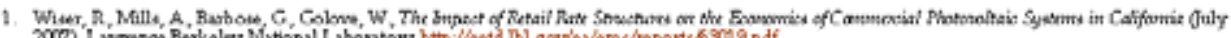

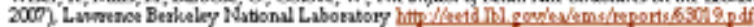

\subsubsection{Federal Incentives}

\section{Methodology 1: Investment Credits}

Federal Incentive $($ cents $/ \mathrm{kWh})=$ Rebate for Cost of Equipment (cents/kWp) x / (Life of System x DC-AC Conversion Factor x Capacity Factor x Annual Hours)

Federal law provides a $30 \%$ income tax credit of up to $\$ 2,000$ for purchase and installation of residential PV and a $30 \%$ tax credit for commercial systems. ${ }^{51}$ At the federal level, there is also 5-year accelerated depreciation. At the residential level, federal incentives generally have a smaller impact than state incentives because of the cap. Thus, residential systems are at the low end, and commercial systems, where there is no cap, are at the high end. We used the following assumptions in our model: 25-year life, DC-AC conversion factor of 0.77 , a capacity factor of $15 \%$, and 8,760 annual hours. The range in Table 17 is based on our model for federal incentives.

\footnotetext{
${ }^{50}$ Wiser, R., Mills, A., Barbose, G., Golove, W., The Impact of Retail Rate Structures on the Economics of Commercial Photovoltaic Systems in California, Lawrence Berkeley National Laboratory (July 2007),

${ }^{51}$ Itron, Inc. CPUC Self-Generation Incentive Program Preliminary Cost-Effectiveness Evaluation Report, (September 14, 2006)
} 
Table 17. Range and Drivers: Federal Incentives

\begin{tabular}{|l|c|l|}
\hline \multicolumn{1}{|c|}{ Range of Value } & Net $(\mathbb{\$} / \mathbf{k W h})$ & \multicolumn{1}{c|}{ Drivers } \\
\cline { 1 - 2 } High End of Range (90\% percentile) & 7.95 & $\begin{array}{l}\text { •Customer segment } \\
\bullet \text { Size of system, as income tax credit is caped }\end{array}$ \\
\cline { 1 - 2 } Low End of Range (10\% percentile) & 1.58 & \\
\hline
\end{tabular}

\subsubsection{State Incentives}

\section{Methodology 1: Initial Investment or Production Credits}

State Incentive (cents/kWh) = Rebate for Cost of Equipment / (Life of System x DC-AC Conversion Factor x Capacity Factor x Annual Hours) + Production (kWh) x Production Credit (cents/kWh)

Incentives vary widely by state. In some states there are no incentives (West Virginia, Wyoming, South Carolina, etc.) while in states such as California they are significant.

In California, the California Solar Initiative (CSI) is managed by the Public Utilities Commission and applies to residential retrofits and commercial and government buildings, and uses a mix of capacity and output based payments. Systems smaller than 100 kilowatt (peak) (kWp) have upfront, expected performance based payments through rate reductions over 10 years. Systems larger than $100 \mathrm{kWp}$ have over time, output based payments through rate reductions over 5 years. The New Solar Home Partnership (NSHP), managed by the California Energy Commission (CEC), applies to new residential housing, residential portions of mixed development, and affordable housing. The incentive program offers buy-downs, in dollars per watt (peak) $(\$ / W p)$, corrected for expected performance through a complex calculation that requires an expert site inspection. ${ }^{52}$ The range in Table 18 is based on our model for state incentives.

Table 18. Range and Drivers: State Incentives

\begin{tabular}{|l|r|l|}
\hline \multicolumn{1}{|c|}{ Range of Value } & Net $(\mathbb{C} / \mathbf{k W h})$ & \multicolumn{1}{c|}{ Drivers } \\
\hline High End of Range $\mathbf{( 9 0 \%}$ percentile) & 17.8 & $\begin{array}{l}\bullet \text { Varies depending on state regulations. } \\
\bullet \text { Varies depending on type of system. }\end{array}$ \\
\cline { 1 - 2 } Low End of Range (10\% percentile) & - & $\bullet$ Varies depending on size of system. \\
\hline
\end{tabular}

\footnotetext{
${ }^{52}$ Database of State Incentives for Renewables \& Efficiency, www.dsireusa.org
} 


\subsection{PV Value Case Studies and Scenarios}

\subsection{Case Studies}

We developed a variety of case studies that allowed for a consistent comparison of PV values for specific situations. Case studies in Texas, California, Minnesota, Wisconsin, Maryland, New York, Massachusetts, and Washington were reviewed. Six of these case studies were residential systems and five were commercial systems. Although, there was incomplete information, in each of the cases, we were able to use our model to provide values for the missing data. The highlighted values in Table 19 are values taken directly from the case or values that have been calculated indirectly from the case. The medium value was chosen as a default for each missing value except for the GHG scenario and the equipment and installation costs. A "low value" of \$12/ton was the default for GHG emissions and a "high value" or a 2007 cost was the default for equipment and installation costs.

The first case study that we reviewed came from the Austin Energy Report. The purposes of the Austin Energy Report were to quantify the value of distributed PV to Austin Energy, and to document the evaluation methodologies to assist Austin Energy in performing the analysis as conditions change. We completed the case study by estimating the values not quantified in the report. The values that were quantified in the report are:

- Central power generation cost

- Central power capacity cost

- T\&D costs

- System losses

- Ancillary services

- Criteria pollutant emissions

- GHG emissions

- Implicit value

- Hedge value

- Ancillary services.

A fixed, 30-degree south-facing PV scenario was used in the base case. Clean Power Research has done various scenarios with different orientations and rotations. National averages or Texas region averages (when available) were used for the costs and transfers base case. As Table 19 and Table 20 illustrate, customer participants have a negative value while utilities/ratepayers and society have positive values. It is important to note that in this case study, the central power capacity cost is unusually low because the displaced marginal resource was a base-load gas turbine plant, compared to other studies that consider peaking-plants with limited hours of annual operation as the displaced marginal resource. Another value that is unusually low is the T\&D cost benefit because load growth is occurring mostly in suburban areas with relatively low T\&D costs. Two cases were reviewed for Austin Energy - a residential system analysis and a commercial system analysis. The commercial system has a higher net value because the levelized cost of equipment and installation is lower. 
Table 19. Case 1 Summary Austin Energy Residential System

\begin{tabular}{|c|c|c|c|c|c|}
\hline & PV Values & $\begin{array}{l}\text { Customer/ } \\
\text { Participant } \\
\text { ( } / \mathrm{kWh} \text { ) }\end{array}$ & $\begin{array}{l}\text { Utility / } \\
\text { Ratepayers } \\
\text { ( } \mathrm{k} / \mathrm{kWh})\end{array}$ & Society ( $\mathbf{c} / \mathbf{k W h})$ & Net $(\boldsymbol{c} / \mathbf{k W h})$ \\
\hline \multirow{10}{*}{ 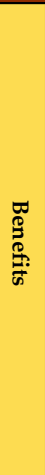 } & Central Power Generation Cost & - & 7.0 & - & 7.0 \\
\hline & Central Power Capacity Cost & - & 1.1 & - & 1.1 \\
\hline & T\&D Costs & - & 0.1 & - & 0.1 \\
\hline & System Losses & - & 0.6 & - & 0.6 \\
\hline & Ancillary Services & & 0.8 & & 0.8 \\
\hline & Hedge Value & & $0.0^{*}$ & & 0.0 \\
\hline & Customer Price Protection & & 0.8 & & 0.8 \\
\hline & Criteria Pollutant Emissions & \multirow{3}{*}{-} & \multirow{3}{*}{ - } & \multirow{3}{*}{$2.0^{* *}$} & \multirow{3}{*}{2.0} \\
\hline & Greenhouse Gas Emissions & & & & \\
\hline & Implicit Value & & & & \\
\hline \multirow{3}{*}{$\frac{8}{8}$} & Equipment and Installation & $(29.3)$ & - & - & (30.6) \\
\hline & PV O\&M Expenses & $(0.1)$ & - & - & (0.1) \\
\hline & Benefits Overhead & $(0.2)$ & & & $(0.2)$ \\
\hline \multirow{3}{*}{ 承 } & PV Owner Electricity Bill & 6.3 & (6.3) & - & - \\
\hline & Federal Incentives & 1.6 & - & (1.6) & - \\
\hline & State Incentives & 0.0 & - & 0.0 & - \\
\hline & Stakeholder Total & (20.9) & 3.3 & 0.4 & (17.2) \\
\hline
\end{tabular}

* Hedge value included in generation value

** Case looked as these values as one entity

Table 20. Case 2 Summary Austin Energy Commercial System

\begin{tabular}{|c|c|c|c|c|c|}
\hline & PV Values & $\begin{array}{c}\text { Customer/ } \\
\text { Participant } \\
\text { ( } / \mathrm{kWh} \text { ) }\end{array}$ & $\begin{array}{l}\text { Utility / } \\
\text { Ratepayers } \\
\text { (c/kWh) }\end{array}$ & Society $(\mathbb{c} / \mathbf{k W h})$ & Net ( $\$$ /kWh) \\
\hline \multirow{10}{*}{ 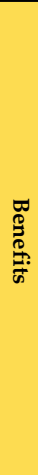 } & Central Power Generation Cost & - & 7.0 & - & 7.0 \\
\hline & Central Power Capacity Cost & - & 1.1 & - & 1.1 \\
\hline & T\&D Costs & - & 0.1 & - & 0.1 \\
\hline & System Losses & - & 0.6 & - & 0.6 \\
\hline & Ancillary Services & & 0.8 & & 0.8 \\
\hline & Hedge Value & & $0.0^{*}$ & & 0.0 \\
\hline & Customer Price Protection & 0.8 & & & 0.8 \\
\hline & Criteria Pollutant Emissions & \multirow{3}{*}{ - } & \multirow{3}{*}{-} & \multirow{3}{*}{$2.0^{* *}$} & \multirow{3}{*}{2.0} \\
\hline & Greenhouse Gas Emissions & & & & \\
\hline & Implicit Value & & & & \\
\hline \multirow{3}{*}{$\begin{array}{l}\stackrel{8}{\frac{p}{\omega}} \\
\frac{1}{2}\end{array}$} & Equipment and Installation & $(26.5)$ & - & - & (26.5) \\
\hline & PV O\&M Expenses & $(0.1)$ & - & - & $(0.1)$ \\
\hline & Benefits Overhead & $(0.2)$ & & & $(0.2)$ \\
\hline \multirow{3}{*}{ 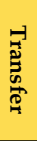 } & PV Owner Electricity Bill & 4.6 & $(4.6)$ & - & - \\
\hline & Federal Incentives & 7.9 & - & (7.9) & - \\
\hline & State Incentives & 0.0 & - & 0.0 & - \\
\hline & Stakeholder Total & (13.4) & 4.9 & (5.9) & (14.4) \\
\hline
\end{tabular}

Source: Highlighted values from case study. Other values estimated from NCI model. 
The third case we reviewed was for a newly constructed residential home in Northfield, Minnesota. ${ }^{53}$ The system consisted of 180 roof-mounted solar shingles with a combined nameplate capacity of $3.1 \mathrm{~kW}$. The shingles are UniSolar 1 amorphous silicon thin-film cells, model SHR 17. This study was called "Minnesota Photovoltaic System Study: Residential Application." The actual equipment and installation costs, at 38.9 cents $/ \mathrm{kWh}$, were higher than our model predicted.

Table 21. Case 3 Summary New Residential Home in Northfield, MN

\begin{tabular}{|c|c|c|c|c|c|}
\hline \multicolumn{2}{|c|}{ PV Values } & \multirow{2}{*}{$\begin{array}{c}\text { Customer' } \\
\text { Participant } \\
\text { (tekWWy }\end{array}$} & \multirow{2}{*}{$\begin{array}{c}\text { Utiuty/ } \\
\text { Ratepayers } \\
\text { (cikwh }\end{array}$} & \multirow{2}{*}{ Soclety (C/kWh) } & \multirow{2}{*}{$\frac{\text { Net (e/kWh) }}{6.8}$} \\
\hline \multirow{10}{*}{$\frac{\pi}{g}$} & Central Power Generation Cost & & & & \\
\hline & Central Power Capacity Cost & - & 60 & - & 6.0 \\
\hline & T\&D Costs & - & 5.1 & - & 5.1 \\
\hline & System Loases & - & 07 & - & 0.7 \\
\hline & Aneillary Services & & 08 & & 0.8 \\
\hline & Hedge Value & & 0.5 & & 0.5 \\
\hline & Customer Price Protection & 0.8 & - & & 0.5 \\
\hline & Criteria Pollutant Emisasons & & & 36 & 3.6 \\
\hline & Greenhouse Gas Emiseions & & & 4.3 & 4.3 \\
\hline & Implieit Value & & & 10 & 1.0 \\
\hline \multirow{3}{*}{$\frac{2}{2}$} & Equipment and Installation & $(30.9)$ & - & - & (35.9) \\
\hline & PV OseM Expenses & $(0.1)$ & - & - & $(0.1)$ \\
\hline & Benefits Overhead & $(0.2)$ & & & 10.23 \\
\hline \multirow{3}{*}{$\frac{\overrightarrow{2}}{2}$} & PV Owner Electrieity Bull & 7.2 & (7.2) & . & - \\
\hline & Federal Incentives & 1.6 & - & $(1.6)$ & - \\
\hline & State Incentives & 7.9 & - & $(7.9)$ & - \\
\hline & Stakeholder Total & (21.5) & 125 & $(0.6)$ & (9.9) \\
\hline
\end{tabular}

The fourth case we reviewed was for another new residential home that was constructed in Madison, Wisconsin, in which the cost equipment and installation costs were lower and the owner's electricity bill savings were higher. ${ }^{54}$ The system is pole-mounted with dual-axis tracking with a nameplate capacity of $1.264 \mathrm{~kW}$. It consists of Kyocera panels, an SMA inverter, and a WattSun tracker. The study was called "Wisconsin Focus on Energy Case Study: Solar Energy in the City."

\footnotetext{
${ }^{53}$ Minnesota Photovoltaic System Case Study: Residential Application. Prepared for Iowa Department of Natural Resources. Copyright Black \& Veatch (May, 2003)

${ }^{54}$ Wisconsin Focus On Energy Case Study: Solar Energy in the City. REN-2044-1104 (2004)
} 
Table 22. Case 4 Summary New Residential Home in Madison, WI

\begin{tabular}{|c|c|c|c|c|c|}
\hline \multicolumn{2}{|c|}{ PV Values } & \multirow{2}{*}{$\begin{array}{l}\text { Customer' } \\
\text { Participant } \\
\text { (t) kWW }\end{array}$} & \multirow{2}{*}{$\begin{array}{c}\text { Utulty } \\
\text { Ratepayers } \\
\text { (c/kwh }\end{array}$} & \multirow{2}{*}{ Society (C/NWh) } & \multirow{2}{*}{$\begin{array}{c}\text { Net }(C / k W h) \\
6.8\end{array}$} \\
\hline \multirow{10}{*}{ 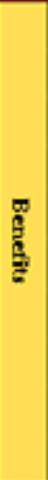 } & Central Power Generation Cost & & & & \\
\hline & Central Power Capacity Coat & - & 60 & - & 6.0 \\
\hline & T\&D Costs & - & 5.1 & - & 5.1 \\
\hline & System Lasoes & - & 0.7 & - & 0.7 \\
\hline & Aneillary Services & & 0.8 & & 0.8 \\
\hline & Hedge Value & & 0.5 & & 0.5 \\
\hline & Customer Price Protection & 0.0 & - & & 0.8 \\
\hline & Criteria Pollutant Emiasions & & & 21 & 2.1 \\
\hline & Greenhouse Gas Emissions & & & 0.7 & 0.7 \\
\hline & Implieit Value & & & 10 & 1.0 \\
\hline \multirow{3}{*}{$\begin{array}{l}0 \\
\text { है }\end{array}$} & Equipment and Installation & $(23,6)$ & - & - & (23.8) \\
\hline & PV Os:M Expenses & (0.1) & - & - & 10.11 \\
\hline & Benefits Overhesd & $(0.2)$ & & & 10.23 \\
\hline \multirow{3}{*}{$\overrightarrow{5}$} & PV Owner Flectrieity Bull & 10.3 & $(10.3)$ & - & - \\
\hline & Federal Incentives & 1.6 & - & $(1.6)$ & - \\
\hline & State Incentives & 0.0 & - & 0.0 & $\cdot$ \\
\hline & Stakeholder Total & (11.4) & 9.4 & 2.3 & 0.2 \\
\hline
\end{tabular}

The fifth case was based on the DOE Million Roofs Initiative success stories and was for a residential home in Glenn Dale, Maryland. ${ }^{55}$ The system consisted of roof-mounted amorphous silicon thin-film cells and had a nameplate capacity of $1.4 \mathrm{~kW}$. It used BP Solarex Millennia panels and an Omnion inverter. It was indeed a success as the equipment and installation costs were low and the savings were high, yielding a relatively high net value.

\footnotetext{
${ }^{55}$ Million Solar Roofs Initiative: Success Stories. Residential Installation, On-Grid PV System, DOE, Glenn Dale, MD
} 
Table 23. Case 5 Summary Existing Residential Home in Glenn Dale, MD

\begin{tabular}{|c|c|c|c|c|c|}
\hline \multicolumn{2}{|c|}{ PV Values } & \multirow{2}{*}{$\begin{array}{l}\text { Customer' } \\
\text { Participant } \\
\text { (t)/kWh) }\end{array}$} & \multirow{2}{*}{$\begin{array}{c}\begin{array}{c}\text { Utiuty } f \\
\text { Ratepayers } \\
\text { (t)/kwh }\end{array} \\
68\end{array}$} & \multirow{2}{*}{ Society (C/kWh) } & \multirow{2}{*}{$\begin{array}{c}\text { Net (C/kWh) } \\
6.8\end{array}$} \\
\hline \multirow{10}{*}{$\frac{\mathbb{a}}{\mathfrak{E}}$} & Central Power Generation Cost & & & & \\
\hline & Centrul Power Capacity Coat & - & 60 & $=$ & 1.1 \\
\hline & T\&D Costs & - & 5.1 & - & 0.1 \\
\hline & System Lasaes & - & 0.7 & - & 0.6 \\
\hline & Aneillary Services & & 0.8 & & 0.8 \\
\hline & Hedge Value & & 0.5 & & 0.0 \\
\hline & Customer Price Protection & 0.8 & - & & $0 . s$ \\
\hline & Criteria Pollutant Emisaions & & & 21 & 2.1 \\
\hline & Greenhouse Gas Emissions & & & 15 & 1.5 \\
\hline & Implieit Value & & & 10 & 1.0 \\
\hline \multirow{3}{*}{ @ } & Equipment and Installation & $(23,6)$ & - & - & $(23.8)$ \\
\hline & PV Os:M Expenses & (0.1) & - & - & 10.11 \\
\hline & Benefits Overhesd & $(0.2)$ & & & 10.23 \\
\hline \multirow{3}{*}{$\frac{\overrightarrow{7}}{2}$} & PV Owner Electricity Bill & 10.3 & $(103)$ & $=$ & $\cdot$ \\
\hline & Federal Incentives & 1.6 & - & (1.6) & - \\
\hline & State Incentives & 0.0 & - & 0.0 & $\cdot$ \\
\hline & Stakeholder Total & (11.4) & 9.4 & 2.3 & (4.9) \\
\hline
\end{tabular}

The following study was a case study on the New York Energy \$Mart program. ${ }^{56}$ The system consisted of 90 roof-mounted panels covering 900 square feet ( $\mathrm{sq} \mathrm{ft}$ ). It had a nameplate capacity of $14.85 \mathrm{~kW}$.

${ }^{56}$ New York Energy \$mart. Darmstadt Overhead Doors. (November, 2004) 
Table 24. Case 6 Summary Existing Commercial Building in Kingston, NY

\begin{tabular}{|c|c|c|c|c|c|}
\hline & 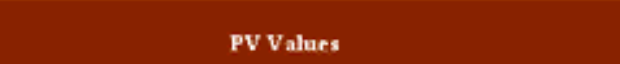 & \multirow{2}{*}{$\begin{array}{c}\text { Customer' } \\
\text { Participant } \\
\text { (t)/kWh } \\
-\end{array}$} & \multirow{2}{*}{ 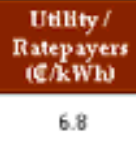 } & \multirow{2}{*}{$\begin{array}{c}\text { Society (C/kWh) } \\
-\end{array}$} & \multirow{2}{*}{$\begin{array}{c}\text { Net (C/kWh) } \\
6.5\end{array}$} \\
\hline \multirow{10}{*}{ 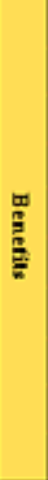 } & Central Power Generation Coet & & & & \\
\hline & Central Power Capacity Cost & - & 6.0 & $\cdot$ & 6.0 \\
\hline & T\&D Costs & - & 5.1 & $\cdot$ & 5.1 \\
\hline & System Losses & - & 0.7 & - & 0.7 \\
\hline & Ancillary Services & & 0.0 & & 0.8 \\
\hline & Hedge Value & & 0.5 & & 0.5 \\
\hline & Customer Price Protection & 0.8 & - & & 0.5 \\
\hline & Criteria Pollutant Emissions & & & 1.4 & 1.4 \\
\hline & Greenhouse Gas Emissions & & & 0.4 & 0.4 \\
\hline & Implicit Value & & & 1.0 & 1.0 \\
\hline \multirow{3}{*}{$\stackrel{8}{8}$} & Equipment and Installation & $(314)$ & $=$ & 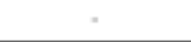 & $(31.4)$ \\
\hline & PV OscM Expenses & $(0.1)$ & - & - & (0.1) \\
\hline & Benefits Overhead & $(0.2)$ & & & (0.2) \\
\hline \multirow{3}{*}{ 产 } & PV Owner Electricity Bill & 1.7 & $(1.7)$ & - & - \\
\hline & Federal Incentives & 79 & $=$ & $(7.9)$ & $\cdot$ \\
\hline & State Incentives & 17.8 & - & $(17.8)$ & - \\
\hline & Stakeholder Total & (3.5) & 10.0 & $(23.0)$ & (8.6) \\
\hline
\end{tabular}

In this study there were only a small amount of savings yielding a low net value.

The seventh case study was based on a study by the University Massachusetts aiming to determine the effect of PV on demand charges. ${ }^{57}$ The system consisted of 241 horizontally roof-mounted Evergreen Solar EC 110 Modules and 17 SMA SB1800U inverters. It had a nameplate capacity of $26.95 \mathrm{~kW}$.

${ }^{57}$ Effect of PV on Reducing Demand Charges: Case Study of a $26 \mathrm{~kW}$ PV System in MA, Ujjwal Bhattacharjee and John Duffy. Energy Engineering Program, University of Massachusetts Lowell (2006) 
Table 25. Case 7 Summary Existing Commercial Building in Cambridge, MA

\begin{tabular}{|c|c|c|c|c|c|}
\hline & 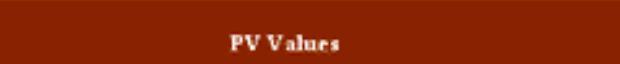 & \multirow{2}{*}{$\begin{array}{c}\text { Customer' } \\
\text { Participant } \\
\text { (t)/kWh } \\
-\end{array}$} & \multirow{2}{*}{ 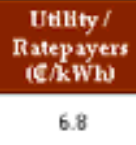 } & \multirow{2}{*}{$\begin{array}{c}\text { Society (C/kWh) } \\
-\end{array}$} & \multirow{2}{*}{$\begin{array}{c}\text { Net (C/kWh) } \\
6.5\end{array}$} \\
\hline \multirow{10}{*}{ 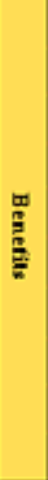 } & Central Power Generation Coet & & & & \\
\hline & Central Power Capacity Cost & - & 6.0 & $\cdot$ & 6.0 \\
\hline & T\&D Costs & - & 5.1 & $\cdot$ & 5.1 \\
\hline & System Losses & - & 0.7 & - & 0.7 \\
\hline & Ancillary Services & & 0.0 & & 0.8 \\
\hline & Hedge Value & & 0.5 & & 0.5 \\
\hline & Customer Price Protection & 0.8 & - & & 0.5 \\
\hline & Criteria Pollutant Emissions & & & 1.4 & 1.4 \\
\hline & Greenhouse Gas Emissions & & & 0.3 & 0.3 \\
\hline & Implicit Value & & & 1.0 & 1.0 \\
\hline \multirow{3}{*}{$\stackrel{8}{8}$} & Equipment and Installation & $(521)$ & $=$ & 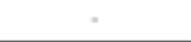 & $(31.4)$ \\
\hline & PV OscM Expenses & $(0.1)$ & - & - & (0.1) \\
\hline & Benefits Overhead & $(0.2)$ & & & (0.2) \\
\hline \multirow{3}{*}{ 产 } & PV Owner Electricity Bill & 1.1 & (1.1) & - & - \\
\hline & Federal Incentives & 79 & $=$ & (79) & $\cdot$ \\
\hline & State Incentives & 7,9 & - & $(7.9)$ & - \\
\hline & Stakeholder Total & $(34.7)$ & 19.0 & $(13.2)$ & $(29.4)$ \\
\hline
\end{tabular}

In this report there were very large equipment and installation costs and low electricity bill savings, again yielding a very low net value.

The next case was a study by the San Diego Regional Energy Office. ${ }^{58}$ The system consisted of 9,700 roof-mounted panels with a total nameplate capacity of $970 \mathrm{~kW}$. It was installed on the Del Mar Fairgrounds of San Diego County.

${ }^{58}$ San Diego Regional Energy Office. Del Mar Fairgrounds SelfGen Case Study 
Table 26. Case 8 Summary, Existing Municipal in Del Mar, CA

\begin{tabular}{|c|c|c|c|c|c|}
\hline & 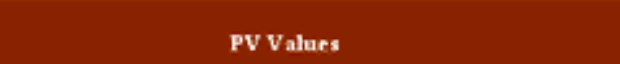 & \multirow{2}{*}{$\begin{array}{c}\text { Customer' } \\
\text { Participant } \\
\text { (t)/kWh } \\
-\end{array}$} & \multirow{2}{*}{ 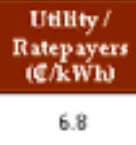 } & \multirow{2}{*}{$\begin{array}{c}\text { Society (C/kWh) } \\
-\end{array}$} & \multirow{2}{*}{$\begin{array}{c}\text { Net (C/kWh) } \\
6.5\end{array}$} \\
\hline \multirow{10}{*}{ 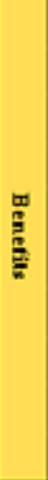 } & Central Power Generation Coet & & & & \\
\hline & Central Power Capacity Cost & - & 6.0 & $\cdot$ & 6.0 \\
\hline & T\&D Costs & - & 5.1 & $\cdot$ & 5.1 \\
\hline & System Losses & - & 0.7 & - & 0.7 \\
\hline & Ancillary Services & & 0.0 & & 0.8 \\
\hline & Hedge Value & & 0.5 & & 0.5 \\
\hline & Customer Price Protection & 0.8 & - & & 0.5 \\
\hline & Criteria Pollutant Emissions & & & 1.4 & 1.4 \\
\hline & Greenhouse Gas Emissions & & & 2.9 & 2.9 \\
\hline & Implicit Value & & & 1.0 & 1.0 \\
\hline \multirow{3}{*}{$\stackrel{8}{8}$} & Equipment and Installation & $(178)$ & $=$ & 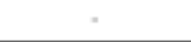 & (17.8) \\
\hline & PV OscM Expenses & $(0.1)$ & - & - & (0.1) \\
\hline & Benefits Overhead & $(0.2)$ & & & (0.2) \\
\hline \multirow{3}{*}{ 产 } & PV Owner Electricity Bill & 15.2 & (15.2) & - & - \\
\hline & Federal Incentives & 79 & $=$ & $(7.9)$ & $\cdot$ \\
\hline & State Incentives & 11.3 & - & (11.3) & - \\
\hline & Stakeholder Total & 172 & 4.4 & $(14.0)$ & 7.6 \\
\hline
\end{tabular}

This retrofit had very high value because of the low equipment and installation costs and high electricity bill savings.

Case nine was based on a study by the Solar Washington Newsletter called "Solar Power Case Study: An Old Idea with New Economics." ${ }^{\text {"T }}$ The system consisted of eight roofmounted Sanyo panels totaling $104 \mathrm{sq} \mathrm{ft}$. It had a nameplate capacity of $1.52 \mathrm{~kW}$.

${ }^{59}$ Solar Power Case Study: An Old Idea With New Economics. John Watts. Solar Washington Newsletter. (Fall, 2006) 
Table 27. Case 9 Summary Existing Residential Home in Bellingham, WA

\begin{tabular}{|c|c|c|c|c|c|}
\hline & 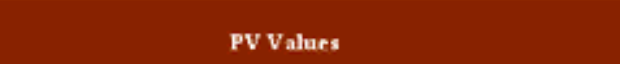 & \multirow{2}{*}{$\begin{array}{c}\text { Customer' } \\
\text { Participant } \\
\text { (ctkWh) } \\
-\end{array}$} & \multirow{2}{*}{$\begin{array}{c}\text { Utulty } / \\
\text { Ratepayers } \\
\text { (c/kwh }\end{array}$} & \multirow{2}{*}{$\begin{array}{c}\text { Society (C/kWh) } \\
-\end{array}$} & \multirow{2}{*}{$\frac{\text { Net (elkWh) }}{6.8}$} \\
\hline \multirow{10}{*}{ 焉 } & Central Power Generation Cost & & & & \\
\hline & Central Power Capacity Cost & - & 6.0 & - & 6.0 \\
\hline & T\&D Costs & - & 5.1 & - & 5.1 \\
\hline & System Losses & - & 0.7 & $\cdot$ & 0.7 \\
\hline & Ancillary Services & & 0.0 & & 0.8 \\
\hline & Hedge Value & & 0.5 & & 0.5 \\
\hline & Customer Price Protection & 0.8 & - & & 0.5 \\
\hline & Criterla Pollutant Emissions & & & 0.7 & 0.7 \\
\hline & Greenhouse Gas Emissions & & & 0.1 & 0.1 \\
\hline & Implicit Value & & & 1.0 & 1.0 \\
\hline \multirow{3}{*}{ ஜ } & Equipment and Installation & $(33.3$ & $=$ & . & (33.3) \\
\hline & PV OscM Expenses & $(0.1)$ & - & - & (0.1) \\
\hline & Benefits Overhead & $(0.2)$ & & & $(0.2)$ \\
\hline \multirow{3}{*}{$\vec{E}$} & PV Owner Electricity Bill & 7.7 & $(7.7)$ & - & $\cdot$ \\
\hline & Federal Incentives & 16 & $=$ & $(1,6)$ & $\cdot$ \\
\hline & State Incentives & 2.2 & - & (2.2) & - \\
\hline & Stakeholder Total & (21_3) & 11.9 & $(2.0)$ & $(11.4)$ \\
\hline
\end{tabular}

Again, high equipment and installation combined with average bill savings resulted in a low net value.

Cases ten and eleven were based on a study by the Center for Sustainable Energy for Million Solar Roofs Initiative in January 2007, called "New York City's Solar Energy Future Part II: Solar Energy Policies and Barriers in New York City." 60 Low installation costs and high incentives created a net positive value.

\footnotetext{
${ }^{60}$ New York City's Solar Energy Future Part II: Solar Energy Policies and Barriers in New York City. Prepared by the Center for Sustainable Energy at Bronx Community College for The City University of New York's Million Solar Roofs Initiative. Appendix VI PV Planner Assumptions for all Sectors. Jan. 2007
} 
Table 28. Case 10 Summary Existing Residential Home in New York, NY

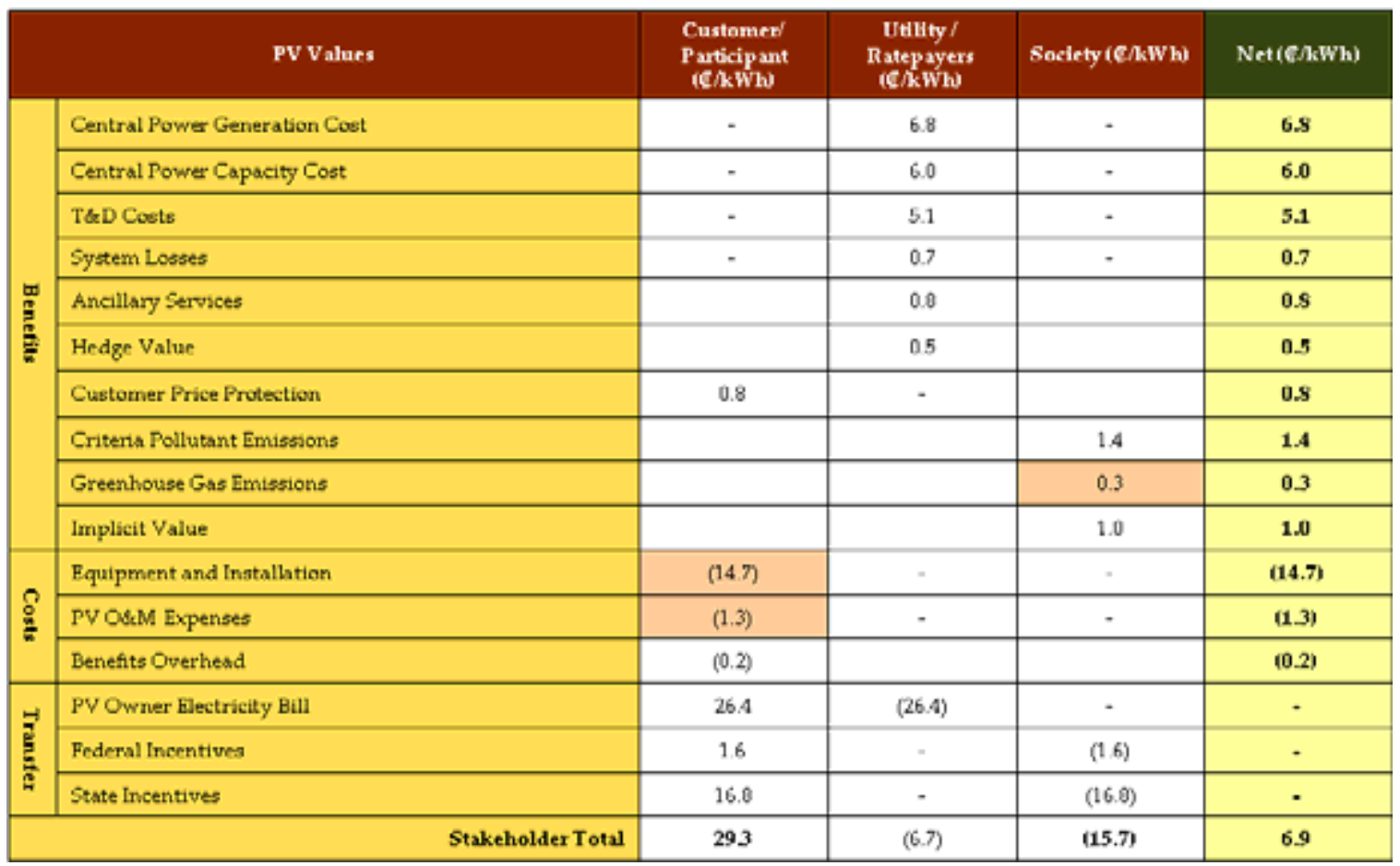

Table 29. Case 11 Summary Existing Commercial Building in New York, NY

\begin{tabular}{|c|c|c|c|c|c|}
\hline \multicolumn{2}{|c|}{ PV Values } & $\begin{array}{l}\text { Customed } \\
\text { Participant } \\
\text { (cikWh) }\end{array}$ & $\begin{array}{c}\text { Utility } \\
\text { Ratepayers } \\
\text { (cikwh) }\end{array}$ & Society (C/kWh) & Net(e/kWh) \\
\hline \multirow{10}{*}{ 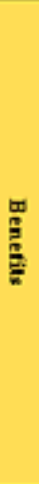 } & Central Power Generation Cost & - & 6.8 & - & 6.5 \\
\hline & Central Power Capacity Cost & - & 6.0 & $\cdot$ & 6.0 \\
\hline & T\&D Costs & - & 5.1 & - & 5.1 \\
\hline & System Losses & - & 0.7 & - & 0.7 \\
\hline & Ancillary Services & & 0.0 & & 0.5 \\
\hline & Hedge Value & & 0.5 & & 0.5 \\
\hline & Customer Price Protection & 0.8 & - & & 0.8 \\
\hline & Criterla Pollutant Emissons & & & 1.4 & 1.4 \\
\hline & Greenhouse Gas Emissions & & & 0.3 & 0.3 \\
\hline & Implicit Value & & & 1.0 & 1.0 \\
\hline \multirow{3}{*}{ @ } & Equipment and Installation & (14.7) & $=$ & . & (14.7) \\
\hline & PV O\&M Expenses & $(1.3)$ & - & - & (1.3) \\
\hline & Benefits Overhead & $(0.2)$ & & & (0.2) \\
\hline \multirow{3}{*}{$\frac{1}{5}$} & PV Owner Electricity Bill & 15.7 & $(15.7)$ & - & - \\
\hline & Federal Incentives & 79 & - & (7.9) & $\cdot$ \\
\hline & State Incentives & 17.8 & - & $(17.9)$ & - \\
\hline & Stakeholder Total & 293 & $(6.3)$ & (15.7) & 7.4 \\
\hline
\end{tabular}

\subsection{Scenarios}

In addition to the case studies, we created five scenarios that demonstrate the model capability. The scenarios are a PV system with storage, a low installation and equipment 
cost scenario, a low installation and equipment cost scenario with no incentives, a $\$ 30 /$ ton GHG scenario, and a $\$ 50 /$ ton GHG scenario.

Base Scenario. The base scenario was a retrofit of a residential home in San Diego, California. Below is the base scenario table of values.

Table 30. Base Scenario

\begin{tabular}{|c|c|c|c|c|c|}
\hline & 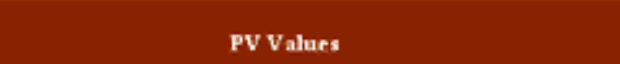 & \multirow{2}{*}{$\begin{array}{c}\text { Customed } \\
\text { Participant } \\
\text { (c/kWh) }\end{array}$} & \multirow{2}{*}{$\begin{array}{c}\text { Utiuty/ } \\
\text { Ratepayers } \\
\text { (c) } k \text { Wh }\end{array}$} & \multirow{2}{*}{$\begin{array}{c}\text { Soclety (C/kWh) } \\
-\end{array}$} & \multirow{2}{*}{$\begin{array}{c}\text { Net(e/kWh) } \\
6.5\end{array}$} \\
\hline \multirow{10}{*}{ 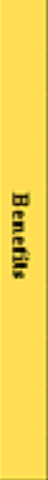 } & Central Power Generation Cost & & & & \\
\hline & Central Powrer Capacity Cost & - & 6.0 & - & 6.0 \\
\hline & T\&D Coets & - & 5.1 & - & 5.1 \\
\hline & System Losses & - & 0.7 & - & 0.7 \\
\hline & Ancillary Services & & 0.0 & & $0 . s$ \\
\hline & Hedge Value & & 0.5 & & 0.5 \\
\hline & Customer Price Protection & 0.8 & - & & 0.8 \\
\hline & Criteria Pollutant Emissions & & & 1.4 & 1.4 \\
\hline & Greenhouse Gas Emissions & & & 0.4 & 0.4 \\
\hline & Implicit Value & & & 1.0 & 1.0 \\
\hline \multirow{3}{*}{$\frac{8}{\hbar}$} & Equipment and Installation & $(29.3)$ & $=$ & . & (29.3) \\
\hline & PV OscM Expenses & $(0.1)$ & - & $\cdot$ & (0.1) \\
\hline & Benefits Overhesd & $(0.2)$ & & & $(0.2)$ \\
\hline \multirow{3}{*}{$\vec{E}$} & PV Owner Electricity Bill & 14.0 & $(14.0)$ & - & $\cdot$ \\
\hline & Federal Incentives & 26 & $=$ & (26) & - \\
\hline & State Incentives & 12.8 & - & $(120)$ & - \\
\hline & Stakeholdex Total & 0.7 & 5.7 & (12.8) & (6.4) \\
\hline
\end{tabular}

Scenario 1 -Storage. The first scenario is a PV system with storage. Values were obtained from the Storage and Controls Report from DOE's Office of Energy Efficiency and Renewable Energy (EERE) and NREL. ${ }^{61}$ In this report, the additional value of outage protection provided by the storage was $\$ 245 /$ year for a residential system. The cost of the battery $(3 \mathrm{kWh})$ was $\$ 900$ and the lifetime of the battery was 7 years. Thus, the additional cost was 1.40 cents/kWh and the value of reliability was 2.7 cents $/ \mathrm{kWh}$. Another potential scenario could involve customers using more expensive storage systems for energy arbitrage opportunities in addition to back-up power.

\footnotetext{
${ }^{61}$ Hoff, T.E., Perez, R., Braun, Margolis, R M., Maximizing the Value of Customer-Sited PV Systems Using Storage and Controls, NREL (2005)
} 
Table 31. Scenario 1 - Storage

\begin{tabular}{|c|c|c|c|c|c|}
\hline \multicolumn{2}{|c|}{ PV Values } & \multirow{2}{*}{$\begin{array}{l}\text { Custamer' } \\
\text { Participant } \\
\text { (c/kWh } \\
\text { - }\end{array}$} & \multirow{2}{*}{$\begin{array}{c}\text { Utiuty/ } \\
\text { Ratepayers } \\
\text { (cikwh) }\end{array}$} & \multirow{2}{*}{ Society (C/kWh) } & \multirow{2}{*}{$\begin{array}{c}\text { Net (e/kWh) } \\
6.5\end{array}$} \\
\hline \multirow{11}{*}{ 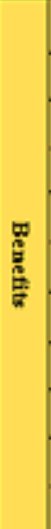 } & Central Power Generation Cost & & & & \\
\hline & Central Powrer Capacity Cost & - & 6.0 & 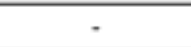 & 6.0 \\
\hline & T\&D Costs & - & 5.1 & - & 5.1 \\
\hline & System Losses & - & 24 & - & 2.4 \\
\hline & Ancillary Services & - & 0.0 & - & $0 . s$ \\
\hline & Hedge Value & $=$ & 0.5 & . & 0.5 \\
\hline & Customer Price Protection & 0.8 & - & - & 0.8 \\
\hline & Customer Reliability & 27 & - & - & 2.7 \\
\hline & Criterta Pollutant Emissons & - & - & 1.4 & 1.4 \\
\hline & Greenhouse Gas Emiseions & - & - & 0.4 & 0.4 \\
\hline & Implieit Value & $=$ & - & 1.0 & 1.0 \\
\hline \multirow{3}{*}{$\begin{array}{l}0 \\
g \\
g \\
g\end{array}$} & Equipment and Installation & $(30,7)$ & - & - & $(30.7)$ \\
\hline & PV OScM Expenses & $(0.1)$ & - & - & (0.1) \\
\hline & Benefits Overhesd & $(0.2)$ & - & - & 10.21 \\
\hline \multirow{3}{*}{$\frac{1}{2}$} & PV Owner Electrietty Btl & 140 & $(140)$ & - & $\cdot$ \\
\hline & Federal Incentives & 26 & - & $(2.6)$ & - \\
\hline & State Incentives & 12.8 & - & $(120)$ & $\cdot$ \\
\hline & Stakeholder Total & 2.0 & 7.1 & $(12.8)$ & $(3.7)$ \\
\hline
\end{tabular}

Scenario 2 - Low Cost. The second scenario is a low installation and equipment cost scenario. The values for this scenario were obtained from our model. The assumptions for this scenario included projecting the costs out to 2015 , which decrease annually at $4 \%$ to $6 \%$ per year. 
Table 32. Scenario 2 - Low Cost

\begin{tabular}{|c|c|c|c|c|c|}
\hline & 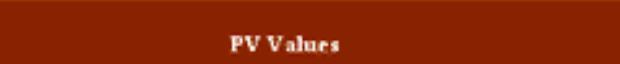 & $\begin{array}{l}\text { Customerf } \\
\text { Participant }\end{array}$ & $\begin{array}{c}\text { Utibty/ } \\
\text { Ratepayers }\end{array}$ & Saciety (C/kWh) & Net $(C / \mathrm{k} W \mathrm{~h})$ \\
\hline \multirow{10}{*}{ 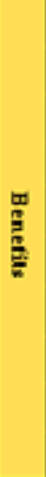 } & Central Power Generation Cost & - & 6.8 & - & 6.8 \\
\hline & Central Power Capacity Cost & - & 10.0 & - & $10 \mathrm{~s}$ \\
\hline & T\&D Costs & - & 10.0 & - & 10.0 \\
\hline & System Losses & - & 0.7 & $\cdot$ & 0.7 \\
\hline & Ancillary Services & - & 0.0 & - & 0.5 \\
\hline & Hedge Value & - & 0.5 & - & 0.5 \\
\hline & Customer Price Protection & 0.8 & - & - & 0.5 \\
\hline & Criteria Pollutant Emissions & - & - & 1.4 & 1.4 \\
\hline & Greenhouse Gas Emissions & - & - & 0.4 & 0.4 \\
\hline & Implicit Value & - & - & 1.0 & 1.0 \\
\hline \multirow{3}{*}{$\stackrel{\wp}{\frac{0}{n}}$} & Equipment and Installation & $(19.0)$ & $=$ & . & (19.0) \\
\hline & PV OseM Expenses & $(0.1)$ & - & - & (0.1) \\
\hline & Benefits Overhead & $(0.2)$ & - & - & (0.2) \\
\hline \multirow{3}{*}{$\overrightarrow{\vec{E}}$} & PV Owner Electricity Bill & 14.0 & $(14.0)$ & - & $\cdot$ \\
\hline & Federal Incentives & 26 & $=$ & (26) & - \\
\hline & State Incentives & 12.8 & - & $(120)$ & - \\
\hline \multicolumn{2}{|r|}{ Stakeholder Total } & 11 & 5.7 & (12.8) & 39 \\
\hline
\end{tabular}

This created a net positive value and a positive value for the customer/participant. The third scenario is a low cost installation and equipment cost scenario with no incentives.

Scenario 3 - Low Cost and No Incentives. We used the same assumptions as in the previous scenario and did not include any state or federal incentives in the value analysis. 
Table 33. Scenario 3 - Low Cost and No Incentives

\begin{tabular}{|c|c|c|c|c|c|}
\hline \multicolumn{2}{|c|}{ PV Values } & \multirow{2}{*}{$\begin{array}{c}\text { Customer' } \\
\text { Participant } \\
\text { (C/kWh) } \\
-\end{array}$} & \multirow{2}{*}{$\begin{array}{c}\begin{array}{c}\text { Utiuty f } \\
\text { Ratepayers } \\
\text { (c/kwh }\end{array} \\
6.8\end{array}$} & \multirow{2}{*}{$\begin{array}{c}\text { Society (C/kWh) } \\
-\end{array}$} & \multirow{2}{*}{$\frac{\text { Net }(C / \mathrm{k} W \mathrm{~W})}{6.8}$} \\
\hline \multirow{10}{*}{ 兽 } & Central Power Generation Cost & & & & \\
\hline & Central Power Capacity Cost & - & 10.0 & - & $10 S$ \\
\hline & T\&D Costs & - & 10.0 & $\cdot$ & 10.0 \\
\hline & System Losses & - & 0.7 & $\cdot$ & 0.7 \\
\hline & Ancillary Services & - & 0.0 & $\cdot$ & $0 . s$ \\
\hline & Hedge Value & $=$ & 0.5 & - & 0.5 \\
\hline & Customer Price Protection & 0.8 & - & - & 0.5 \\
\hline & Criteria Pollutant Emissions & - & - & 1.4 & 1.4 \\
\hline & Greenhouse Gas Emissions & - & - & 0.4 & 0.4 \\
\hline & Implicit Value & - & - & 1.0 & 1.0 \\
\hline \multirow{3}{*}{ @ } & Equipment and Installation & $(190)$ & $=$ & . & (19.0) \\
\hline & PV OstM Expenses & $(0.1)$ & - & - & (0.1) \\
\hline & Benefits Overhead & $(0.2)$ & - & - & $(0.2)$ \\
\hline \multirow{3}{*}{$\vec{g}$} & PV Owner Electricity Bill & 14.0 & $(14.0)$ & - & - \\
\hline & Federal Incentives & - & $=$ & - & $\cdot$ \\
\hline & State Incentives & - & - & - & - \\
\hline \multicolumn{2}{|r|}{ Stakeholder Total } & (4.5) & (5.7) & 2.7 & 39 \\
\hline
\end{tabular}

The overall net value did not change from scenario 2 and remained positive; however, the benefit to the customer participant decreased and the benefit to society increased.

Scenario 4 - GHG Emissions at \$30/ton. The fourth scenario was our first GHG scenario. We used a value of $\$ 30 /$ ton of $\mathrm{CO}_{2}$ for the value of $\mathrm{GHG}-$ a value we thought would have a significant impact on carbon emissions in the United States. 
Table 34. Scenario 4 - Greenhouse Gas Emissions at \$30/ton

\begin{tabular}{|c|c|c|c|c|c|}
\hline & 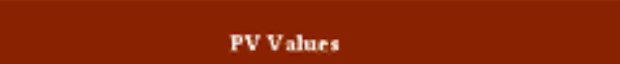 & \multirow{2}{*}{$\begin{array}{c}\text { Customer } \\
\text { Participant } \\
\text { (tekWh) } \\
\text { - }\end{array}$} & \multirow{2}{*}{$\begin{array}{c}\begin{array}{c}\text { Utiuty f } \\
\text { Ratepayers } \\
\text { (c/kwh }\end{array} \\
6.8\end{array}$} & \multirow{2}{*}{$\begin{array}{c}\text { Society (C/kWh) } \\
-\end{array}$} & \multirow{2}{*}{$\frac{\text { Net }(C / \mathrm{k} W \mathrm{~h})}{6.8}$} \\
\hline \multirow{10}{*}{ 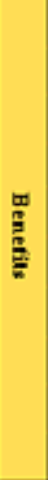 } & Central Power Generation Cost & & & & \\
\hline & Central Power Capacity Cost & - & 10.0 & - & $10 S$ \\
\hline & T\&D Costs & - & 10.0 & $\cdot$ & 10.0 \\
\hline & System Losses & - & 0.7 & $\cdot$ & 0.7 \\
\hline & Ancillary Services & - & 0.0 & $\cdot$ & $0 . s$ \\
\hline & Hedge Value & $=$ & 0.5 & - & 0.5 \\
\hline & Customer Price Protection & 0.8 & - & - & 0.5 \\
\hline & Criteria Pollutant Emissions & - & - & 1.4 & 1.4 \\
\hline & Greenhouse Gas Emissions & - & - & 0.9 & 0.9 \\
\hline & Implicit Value & - & - & 1.0 & 1.0 \\
\hline \multirow{3}{*}{$\stackrel{8}{\circ}$} & Equipment and Installation & $(29.3)$ & $=$ & . & (29.3) \\
\hline & PV OstM Expenses & $(0.1)$ & - & - & (0.1) \\
\hline & Benefits Overhesd & $(0.2)$ & - & - & $(0.2)$ \\
\hline \multirow{3}{*}{$\vec{E}$} & PV Owner Electricity Bill & 14.0 & $(14.0)$ & - & - \\
\hline & Federal Incentives & 26 & $=$ & $(26)$ & $\cdot$ \\
\hline & State Incentives & 12.0 & - & $(120)$ & - \\
\hline & Stakeholder Total & 0.7 & 5.7 & (12.2) & (5.S) \\
\hline
\end{tabular}

This assumption increased the value of GHG emissions to 0.9 cents/kWh; however, benefits to society were still negative overall.

Scenario 5 - GHG Emissions at \$50 per ton. Our last scenario was our second GHG scenario. We used a value of $\$ 50 /$ ton of carbon dioxide; a value we thought the market had the potential to reach in the long term. Table 35 highlights the results of this analysis. 
Table 35. Scenario 5 - Greenhouse Gas Emissions at \$50/ton

\begin{tabular}{|c|c|c|c|c|c|}
\hline \multicolumn{2}{|c|}{ PV Values } & \multirow{2}{*}{$\begin{array}{c}\text { Customer } \\
\text { Participant } \\
\text { (te/kWh) } \\
-\end{array}$} & \multirow{2}{*}{$\begin{array}{c}\text { Utiuty } \\
\text { Ratepayers } \\
\text { (t)ikwh }\end{array}$} & \multirow{2}{*}{$\begin{array}{c}\text { Society (C/kWh) } \\
-\end{array}$} & \multirow{2}{*}{$\frac{\text { Net }(\mathrm{C} / \mathrm{kWh})}{6.8}$} \\
\hline \multirow{10}{*}{ 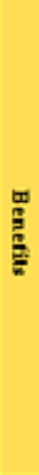 } & Central Power Generation Cost & & & & \\
\hline & Central Power Capacity Cost & - & 10.0 & - & $10 \mathrm{~s}$ \\
\hline & TaD Costs & - & 10.0 & - & 10.0 \\
\hline & System Losses & - & 0.7 & - & 0.7 \\
\hline & Ancillary Services & - & 0.0 & - & 0.5 \\
\hline & Hedge Value & = & 0.5 & = & 0.3 \\
\hline & Customer Price Protection & 0.8 & - & - & 0.5 \\
\hline & Criteria Pollutant Emissions & - & - & 1.4 & 1.4 \\
\hline & Greenhouse Gas Emissions & - & - & 1.5 & 1.5 \\
\hline & Implicit Value & - & - & 1.0 & 1.0 \\
\hline \multirow{3}{*}{$\oint_{\bar{n}}$} & Equipment and Installation & $(29.3)$ & - & . & (29.3) \\
\hline & PV OScM Expenses & $(0.1)$ & - & - & (0.1) \\
\hline & Benefits Overhesd & $(0.2)$ & - & - & (0.2) \\
\hline \multirow{3}{*}{$\frac{\vec{g}}{\mathrm{E}}$} & PV Owner Electricity Bill & 14.0 & $(14.0)$ & - & - \\
\hline & Federal Incentives & 26 & $=$ & (26) & - \\
\hline & State Incentives & 12.8 & - & $(120)$ & - \\
\hline & Stakeholder Total & 0.7 & 5.7 & (11.6) & (5.2) \\
\hline
\end{tabular}

This assumption increased the greenhouse gas emissions value to 1.5 cents $/ \mathrm{kWh}$. 


\subsection{PV Value Gap Analysis}

\subsection{Increasing Benefits from Key PV Values}

We identified gaps between what is needed and what is available so as to make recommendations for improving the value from PV systems. Opportunities to increase the benefits or reduce the costs were focused on PV values with the highest magnitudes. Several strategies were identified for each of the key PV values. The paragraphs below discuss the key PV values and potential ways to improve the benefits or reduce the costs.

\section{Central Power Generation Cost}

Natural gas-fueled power plants are the marginal generation resource in many regions of the United States. As a result, natural gas prices in those regions and the marginal resource heat rate (i.e., the amount of gas consumed to generate a kilowatt-hour) are two key drivers of this value. Given these drivers, a PV system in a region with high gas prices that often displaces electricity from an inefficient peaking power plant will have a much higher benefit than a PV system in a region with low gas prices that displaces mainly off-peak power from an efficient baseload power plant. A strategy to improve the benefit from this value is to increase production from the PV system by optimizing orientation (i.e., latitude and tilt) and using tracking systems.

\section{Central Power Capacity Cost}

The key driver for this value is the coincidence of peak demand with system output. Another key driver is the type of generation asset displaced. Peaking plants typically have lower capital costs than baseload plants. However, a peaking plant that runs a limited number of hours per year will have a higher capital cost per kilowatt-hour than a baseload plant. Given these drivers, a system that produces a high share of its output during onpeak hours and displaces a peaking plant will have a higher benefit. Various strategies to increase production during peak demand periods and increase the benefit from this value include: using thin film technology that has a more consistent output during the day, integrating energy storage into the PV system, and integrating load management applications with the PV system controls.

\section{T\&D Cost}

While this value has significant potential, it has been difficult to capture. This value depends on the location of the PV system as well as the output during the T\&D system's peak period. Locations with congested transmission and/or distribution systems typically require expensive upgrades that could be deferred where PV systems are installed to reduce congestion. Although this value includes both $T \& D$, there are cases that are specific to one or the other. For example, PV can be installed in an area that reduces the transmission peak, but is in a distribution area with excess capacity, providing limited value to the distribution system. However, some of the most congested areas have network distribution systems in which interconnection standards currently prohibit or severely limit interconnections. And in non-network distribution systems, the deferral depends on the production of the PV system during the peak of the specific distribution area, which varies across the distribution system and can be a different peak period than the regional generation peak. 
Many distribution planners will also want "physical assurance" (i.e., guarantees that the load the PV is serving is permanently displaced). Another barrier for this value is the potential for circuit overload following an outage or a recloser operation. Current interconnection standards (e.g., IEEE 1547) prohibit PV systems from riding through outages, leaving the T\&D system to support the loads that would otherwise be served by the PV systems. For a local utility to defer T\&D upgrades and capture the benefits of this value, it will need to assure that the PV system will effectively eliminate a certain load during its peak congestion period and that, if the PV system trips, the customer's connected load will be reduced by an amount equal to the PV output. PV integrated with load management systems would address these concerns and allow PV systems to capture the T\&D cost benefits. Other strategies to increase the benefits captured from this value are to improve the ability to install PV systems in congested areas with limited roof space, and to firm PV output with storage and/or other demand side actions.

\section{Greenhouse Gas and Criteria Pollutant Emissions}

This value is driven by two key factors: the amount of emissions displaced by the PV system and the value of the displaced emissions. PV systems have no emissions and displace all the emissions associated with the marginal central generation resource. In most cases, the marginal resource will be a gas-fueled central generation plant. The higher the heat rate, the higher the displaced emissions. Coincidence of peak demand with PV system output also plays a role in this value because peaking plants tend to have a higher heat rate than baseload plants, producing higher emissions.

As for valuating the displaced emissions, there are various mechanisms currently in place: assessing the public health impact, employing regional air quality district emissions permit trading systems, employing regional renewable energy credit trading systems, assessing the penalties of failing to meet emission standards, and projecting the cost of achieving target emissions reductions. The variety of valuation mechanisms has created a wide range of economic benefits for this value. Moreover, the climate and energy context is evolving quickly and producing an upward trend in the future economic value of the emissions reduction. A strategy to increase the benefits from this value is to support the development and adoption of a uniform valuation standard across the country. A secondary strategy is to increase the amount of displaced emissions by aligning the PV system production with peak demand periods, when dirtier peaking generation plants are the marginal resource.

\section{Implicit Value of PV}

This value is driven by customers' willingness to pay a premium price for electricity from a PV system. For some commercial customers, this value could come from demonstrating to their key stakeholders (customers, investors, employees, and regulators) that the organization is environmentally friendly. For some residential customers, this value could come from a desire to reduce their environmental impact, create an image of being environmentally friendly, and/or create an image of being an early adopter of emerging technologies. The magnitude of this value across market segments is still unclear. Furthermore, this value may change over time as PV penetrates the market. The implicit value may decline as PV becomes more common. Or conversely, PV may become a 
"must-have" product for some sectors of the economy. Understanding what creates this value and how it will change over time will be critical to the success of PV.

\section{Equipment and Installation Cost}

This value is driven by three key factors: system size, location, and projected long-term costs. Large systems have a lower cost per output unit than smaller systems because some PV system costs (e.g., design, engineering, transportation, installation, permitting, and incentive request) are mostly fixed. The location is also a factor because labor rates in some regions are more expensive than others, driving up the labor-intensive costs (e.g., design, engineering, and installation).

As the industry continues to grow and mature, economies of scale and learning curves across the supply chain are expected to reduce overall system costs. However, it is still unclear exactly how much costs will come down, and projections have significant variance. A strategy to reduce the cost from this value is to continue to promote incentives and remove regulatory and market barriers that will help the industry grow and achieve the expected economies of scale. Another strategy is to help capture and disseminate operational best practices from Europe (Germany) and Asia (Japan) across the supply chain to help increase production and decrease costs due to economies of scale and the learning curve effect.

\subsection{Integrating Storage to PV Systems}

Several reports sponsored by EERE and NREL have examined the benefits of integrating storage with PV. ${ }^{62,63}$ Both the outage protection benefits and energy arbitrage opportunities were analyzed. The report, Maximizing the Value of Customer-Sited PV Systems Using Storage and Controls, looked at both a residential and commercial case and found that savings due to outage protection were \$245/year and \$25,000/year respectively. The value was derived from an estimated yearly cost of outage-related disturbances prorated to the relative size of the considered PV system. Load management, outage prevention, and outage recovery were the three values of onsite storage that were defined in this report.

Another report, Increasing the Value of Customer-Owned PV Systems Using Batteries, found that PV storage can have value to both the consumer and utility. This report focused on determining the savings using storage without PV and with PV, and found storage savings to be significant. Cost savings due to a reduction in storage capacity increased the NPV to $\$ 30,000$ (from $\$ 5,000$ ). Obtaining outage cost and associated outage probabilities was difficult to obtain.

While much of the previous research suggests that integrating energy storage equipment into PV systems can improve the value provided by PV systems, more quantification of the benefits for the consumer during an outage or for the utility to control consumer-

\footnotetext{
${ }^{62}$ Hoff, T.E., Perez, R., Braun, Margolis, R M., Increasing the Value of Customer-Owned PV Systems Using Batteries, NREL (November 9 2004)

${ }^{63}$ Hoff, T.E., Perez, R., Braun, Margolis, R M., Maximizing the Value of Customer-Sited PV Systems

Using Storage and Controls, NREL (2005)
} 
owned battery systems in an emergency are areas for future research. Current energy storage technology is still relatively expensive and inefficient. However, R\&D is underway that aims to develop new energy storage technologies that would have significant cost and efficiency improvements over today's technologies. Feasibility studies analyzing the economics of switching from firm to non-firm rates is another area for further study. ${ }^{64}$ In the paragraphs below, we discuss specific examples of opportunities for storage systems to increase the benefits of PV systems.

\section{Optimizing Output Profile during the Day}

Short-term (i.e., hours) storage systems can store energy produced by the PV system during the off-peak period of the day and provide energy and capacity during on-peak periods. By adjusting the output of the PV system to coincide with the peak demand period, the storage system is increasing the benefits along several key values:

- Central power generation cost. Increases the displacement of less efficient peaking plants that have higher operating costs.

- Central power capacity cost. Firms the PV to ensure peak central generation capacity is displaced.

- T\&D costs. Provides greater assurance that the PV can provide T\&D capacity during peak demand periods on the T\&D system to increase the deferral of T\&D upgrades.

- System losses. Increases the avoided losses because they are higher during peak periods.

- GHG and criteria pollutant emissions. Increases the displacement of lower efficiency peaking plants that have higher criteria pollutants.

\section{Increasing Reliability of System Output}

Long-term (i.e., days) energy storage can store energy from the PV system on days with good insolation and release it on days with poor insolation. The storage system is therefore increasing the likelihood that the PV system will be able to consistently offset a certain level of demand. However, it is very expensive to have "days" of storage and most of the benefit can be obtained with small amounts of storage and load control. ${ }^{65}$ Customers will also have reliable back-up power systems that are based on renewable energy, rather than diesel generation. The values with increased benefits from this application are:

- Central power capacity cost. Increases the confidence that PV systems in a certain region will provide a certain level of power on peak demand days and increase the displaced peaking capacity.

\footnotetext{
${ }^{64}$ Hoff, T.E., Perez, R., Margolis, R., Increasing the Value of Customer-Owned PV Systems Using Batteries (November 9, 2004)

${ }^{65}$ Hoff, T.E., Perez, R., Braun, Margolis, R M., Maximizing the Value of Customer-Sited PV Systems Using Storage and Controls, NREL (2005)
} 
- T\&D costs. Increases the confidence that the PV system will provide a certain amount of power on peak demand days and increase the opportunities to defer T\&D investments.

- System resiliency and customer reliability. Increases the confidence that PV systems can provide power during outages. Provides utilities with a resource to supplement the ability of PV to relieve stress on their T\&D systems while supporting customers' critical loads and keeping businesses and residences running. ${ }^{66}$

\subsection{Integrating Demand Response with PV Systems}

A less expensive alternative to energy storage is demand response (also called demand side management or load control applications). By integrating PV systems with demand response, PV systems can more effectively reduce peak demand and the associated central power capacity and T\&D costs. This may be one of the best ways to increase market penetration of PV. When demand is at its highest, relatively expensive PV should be running to capture the market share. Thus, it may serve PV in the long run to assess how it could become fully integrated with demand side management both locally (at point of use) or across the power grid under the potential control of the utility. It could potentially be used to alleviate stress on the grid.

When the output of the PV system is coincident with peak load, demand response can provide assurances to system operators and allow them to rely on the integrated photovoltaic/demand response (PV/DR) system to provide resource adequacy, peak capacity, and peak energy. PV also brings value to demand response. With an integrated PV/DR system the utility would rely less on demand response and the customer would be subject to fewer demand response events.

NREL and EERE reports examined demand response with PV systems. ${ }^{67},{ }^{68}$ In the report, Maximizing the Value of Customer-Sited PV Systems Using Storage and Controls, cumulative cash flows for PV, emergency storage, PV and local load management storage, and PV and emergency storage were compared. In the San Jose commercial case, PV and load control storage had an NPV of \$212,000 while PV alone had an NPV of $\$ 173,000$. In the commercial Long Island case, PV and load control storage had an NPV of $\$ 21,500$ while PV alone had an NPV of $\$ 7,500$. This study concluded that only a small addition of storage for local load control is beneficial for customer-sited PV. In the Report, Maximizing PV Peak Shaving with Solar Load Control: Validation of a WebBased Economic Evaluation Tool, it was found that solar load control can substantially enhance PV load reduction. The solar load control NPV ranged from $\$ 10,000$ to $\$ 100,000$ depending on the size of the building.

\footnotetext{
${ }^{66}$ Hoff, T.E., Perez, R., Braun, Margolis, R M., Maximizing the Value of Customer-Sited PV Systems Using Storage and Controls, NREL (2005)

${ }^{67}$ Ibid

${ }^{68}$ Perez, R., Hoff, T.E., Herig, C., Shah, J., Maximizing PV Peak Shaving with Solar Load Control: Validation of a Web-Based Economic Evaluation Tool (May, 2003)
} 


\subsection{Recommendation for Future Research}

A wealth of previous research has been performed to evaluate the value of PV. However, specific research still needs to be completed to fill in knowledge gaps. We identified opportunities for DOE and NREL to sponsor additional R\&D efforts to improve the quantification of PV values and/or improve the value captured from PV systems. These research efforts will help improve the value of grid connected PV systems, reach economic parity with traditional central generation options, and increase their market penetration. We grouped our recommendations into short-, medium- and long-term focus areas for DOE R\&D.

\section{Short-Term R\&D Recommendations (1-3 years)}

Over the next couple of years, DOE should promote a standard framework and develop tools easily available to industry to assess the value of PV systems. With a few exceptions, our research shows that most of the high magnitude PV values had wellestablished methodologies to quantify the financial impacts, while some of the PV values with lower magnitude PV values do not have generally accepted methods. Although many of these high magnitude values have well established methodologies, there is still disagreement about input assumption, and this is a critical issue.

DOE should look at existing programs that assess the value of PV and could support the next R\&D steps. These include: the Massachusetts Technology Collaborative (MTC), Sacramento Municipal Utility District (SMUD), and Austin Energy. For example, the MTC is undertaking a pilot program to place a large amount of PV within a congested area of the grid to test the actual values of PV. DOE might consider offering to review the results, leverage some dollars to support the analysis of results, and take next steps in funding follow-on R\&D. DOE can also support additional analyses of PV values within utility distribution networks, which the California Energy Commission (CEC) is currently funding.

In addition, DOE should take a leadership role in the development of a standard approach to value GHG and criteria pollutant emissions, including the associated health benefits and intrinsic value of reducing emissions. These are two areas of contention among existing studies that quantify the value of PV. Some studies had a conservative view of benefits while others had high expectations for the future.

Another high-priority, short-term R\&D opportunity for DOE is to fund a robust effort to quantify the costs and benefits associated with integrating current and emerging energy storage systems and demand response applications with PV systems. This effort should go beyond existing efforts and assess both costs and benefits in an approach that involved key stakeholders, including utilities and customers.

\section{Mid-Term R\&D Recommendations (3-5 years)}

Over the mid-term, DOE should collaborate with utilities in the development and deployment of new technologies and operating practices to increase the value captured by utilities and ratepayers from PV systems. These research efforts will help improve the 
value of grid connected PV systems, reach economic parity with traditional central generation options, and increase their market penetration. Specific R\&D opportunities by PV value are presented in Table 36.

\section{Long-Term R\&D Recommendations (5-10 years)}

Over the long term, DOE should take a leadership role in establishing frameworks for long-term policies, regulations, and incentives that will reduce the risks and uncertainty currently limiting investment in PV markets. Solving the technical and analytical challenges over the short- and mid-term will certainly help advance the adoption of PV systems. But to achieve a broad market penetration, appropriate policies, regulations, and incentives will need to be in place. DOE will need to support the development of these mechanisms. 
Table 36. Recommended R\&D to Increase the Value of Grid Interconnected PV

PV Value

Central Power
Capacity Cost

T\&D Costs

Greenhouse Gas and Criteria

Pollutant

Emissions

then

\section{Implicit Value} of PV

\begin{tabular}{|c|}
\hline $\begin{array}{l}\text { System } \\
\text { Resiliency }\end{array}$ \\
\hline $\begin{array}{l}\text { Customer } \\
\text { Reliability }\end{array}$ \\
\hline
\end{tabular}

Reliability

Customer Electric Price

Protection

\begin{tabular}{l|l} 
\\
\end{tabular}

Equipment and Installation Cost

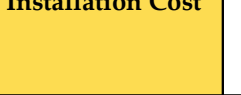

Benefits

Overhead

\section{R\&D Opportunities}

- Assess opportunity to store energy from PV systems on a distributed storage system located on the distribution feeder

- Generally improve the cost and performance of energy storage systems

- Understand how demand response can help PV systems displace central capacity

- Investigate potential improvements to optics in glass of PV modules to enhance performance

- Assess the potential for stranded generation assets for new fossil-fuel power plant investments due to significant changes in fuel costs and/or environmental regulations. Assess the levelized cost of energy from such plants should their economic life be reduced from 30 to 20 or even to 10 years

- Understand how the geographical diversity of PV systems mitigates the short-term output variability due to rapidly changing weather conditions, such as passage of clouds

- As PV reaches significant penetration levels (e.g., $>5 \%$ ), develop guidelines and tools for system planners to predict performance of PV systems (e.g., a day ahead based on weather information) and integrate loading forecasting for wholesale power markets

- Assess actual performance of installed PV systems against predicted performance

- Assess the technical limit for PV penetration on a single distribution circuit (e.g., currently a $15 \%$ compromise agreement in Massachusetts) and define strategies to increase the penetration limit

- Develop the capability to more easily locate PV systems into the "built environment" of congested areas with limited roof space (e.g., PV integrated with roads, bridges and/or rail lines)

- Develop cost-effective engineering solutions to interconnect PV systems to network distribution systems

- Develop cost-effective storage systems

- Explore potential to bundle PV systems with batteries in electric/hybrid vehicles

- Develop cost-effective monitoring, control and validation for performance and physical assurance

- Develop cost-effective engineering solutions to allow PV systems to ride through system outages

- Assess opportunity to integrate demand response to PV systems to improve T\&D benefits

- Assess the technical and economic feasibility of PV-ready distribution systems

- Develop tools for utilities to incorporate PV system output uncertainty into T\&D planning and capacity deferment processes

- Develop easy to use tools for regulators to quantify T\&D values of PV systems in their regions

- Research technical and economical feasibility to use smart grids to manage bidirectional power flows from PV systems and plug-in hybrids

- Launch a consensus based effort to standardize emissions valuation method. While there is some understanding of how to quantify the greenhouse gas emissions displaced by PV systems, there are many approaches being used to value the displaced emissions. This issue goes beyond PV to all greenhouse gas emissions reduction applications. Even though there is much research underway, it is likely that more research will be required to develop a standard valuation approach that is widely accepted and used across the country.

- Incorporate environmental impact into utility dispatch criteria

- Use surveys/focus groups to understand motivations within each stakeholder group (e.g., consumers, developers, utilities) behind PV projects that went ahead even with a negative net present value

- Develop approaches to monetize the value of enhancing the corporate brand

- Understand how the implicit value of PV will change over time; how long will the value of the intangibles last

- Collect data from utilities or on a region-wide basis regarding number of hours of power outage and assess which outage hours could have been avoided by the use of PV with distributed energy storage

- Assess the value of backup power for critical loads that can be provided by PV with distributed energy storage for residential and commercial customer classes

- Develop an accepted methodology to value the certainty of fuel prices

- Develop improved models to forecast long-term electricity prices

- Use surveys/focus groups to understand if and how much price protection is a motivator for PV projects that went ahead even with a negative net present value

- Evaluate current mechanisms used by consumers for energy price hedging.

- Replicate the analysis in the Austin Energy Report with other utilities

- Assess willingness of utilities and practical methods to use PV systems to offer customers fixed electricity prices

- Compare technology requirements in Europe, Japan and the U.S. and assess the impact of codes on PV system design and costs

- Capture and disseminate operational best practices from Europe and Asia across the supply chain that will accelerate the learning curve and reduce costs

- Assess potential for distributing regulated low voltage, PV generated dc power to electronic devices in residential and commercial buildings and the savings from eliminating multiple ac-to-dc power supplies and their associated standby inefficiencies.

- Understand what data and infrastructure (e.g., meters, data management, remote controlling and central monitoring) is required, and what it will take for utilities to rely on PV as a resource

- Understand incentive program management costs (e.g., incentive administration, cost to government, cost to PUCs, cost to installers, cost to customers) and identify ways to reduce these costs (e.g., incentive program standardization across states)

- Develop tools for industry to quickly and easily perform preliminary analysis on the value of specific PV installation projects 


\subsection{Conclusions and Recommendations}

This report provides a series of important conclusions regarding the analysis of PV value:

- Previous efforts to quantify PV values focus on a single stakeholder, typically the participant customer or the utility. When the values across key stakeholders are aggregated, several significant values simply become transfers from one stakeholder to another without creating a net benefit or cost (e.g., PV owner savings on electricity bill, federal incentives, and state incentives).

- While 19 PV values were identified, only 6 have significant benefits (central power generation cost, central power capacity cost, T\&D costs, GHG emissions, criteria pollutant emissions, and implicit value of PV) and one has significant costs (equipment and installation cost).

- The net value of PV systems varies greatly, driven primarily by the location of the system and the output profile (time of day/season).

- Several PV values require additional R\&D to establish a standardized quantification methodology (implicit value of PV, system resiliency, fuel diversity, market price impacts/elasticity, and customer reliability).

- While much of the previous research suggests that integrating energy storage equipment into PV systems can improve the value provided by PV systems, more quantification of the costs and benefits is required.

- There are still many opportunities to increase the benefits of PV systems through R\&D.

It is recommended that NREL and DOE enhance their efforts to fund R\&D that will increase the magnitude and clarity of value from grid connected PV systems. More specifically:

Over the short-term

- Promote a standard framework and develop tools easily available to industry to assess the value of PV systems.

- Take a leadership role in the development of a standard approach to value GHG and criteria pollutant emissions.

- Quantify the costs and benefits associated with integrating current and emerging energy storage systems and demand response applications with PV systems.

Over the mid-term

- Collaborate with utilities in the development and deployment of new technologies and operating practices to increase the value captured by utilities and ratepayers from PV systems. 
Over the long-term

- Take a leadership role in establishing frameworks for long-term policies, regulations, and incentives that will reduce the risks and uncertainty currently limiting investment in PV markets. 


\subsection{References}

ABT Associates; ICF Consulting, (October 2000). The Particulate-Related Health Benefits of Reducing Power Plant Emissions http://www.cleartheair.org/fact/mortality/mortalityabt.pdf

Americans for Solar Power (April 13, 2005). Build-Up of PV Value in California http://www.mtpc.org/renewableenergy/public_policy/DG/resources/2005-04-CA-PVValue-Links-R04-03-017.pdf (“ASPv Report”)

Bhattacharjee, U.; Duffy, J. (2006). "Effect of PV on Reducing Demand Charges: Case Study of a 26 kW PV System in MA" Energy Engineering Program, University of Massachusetts, Lowell, MA http://www.solar2006.org/presentations/tech_sessions/t40-a257.pdf

Center for Sustainable Energy at Bronx Community College (January 2006). New York City's Solar Energy Future. Prepared for The City University of New York's Million Solar Roofs Initiative and Sustainable CUNY/Sustainable NY http://www.bcc.cuny.edu/InstitutionalDevelopment/CSE/Documents/CUNY\%20MSR\%2 0-\%20Market\%20for\%20PV\%20in\%20NYC.pdf

Chambers, A.; Kline, D.M.; Vimmerstedt, L.; Diem, A.; Dismukes, D.; Mesyanzhinov, D. (July 2005). "Comparison of Methods for Estimating the NOx Emission Impacts of Energy Efficiency and Renewable Energy Projects: Shreveport, Louisiana Case Study." NREL TP-710-37721. Golden, CO: National Renewable Energy Laboratoryhttp://www.nrel.gov/docs/fy05osti/37721.pdf

Del Chiaro, B.; Dutzik, T.; Vasavada, J.; (December, 2004). The Economics of Solar Homes in California. Los Angeles, CA: Environment California Research and Policy Center http://www.environmentcalifornia.org/uploads/J9/Kx/J9Kx6frBT7ZsGHGr3uUL9g/Econ omics_of_Solar_Homes.pdf

Duke, R.; Williams, R.: Payne, A. (2001) "Accelerating Residential PV Expansion: Demand Analysis for Competitive Electricity Markets." Energy Policy Vol.29; pp. 787 800.

http://www.princeton.edu/ cmi/research/Capture/Papers/accelerating.pdf

Energy and Environmental Economics, Inc.; Rocky Mountain Institute. (October 25, 2004) Methodology and Forecast of Long Term Avoided Costs for the Evaluation of California Energy Efficiency Programs. San Francisco, CA http://www.ethree.com/cpuc/E3_Avoided_Costs_Final.pdf 
Florida Public Service Commission; Florida Department of Environmental Protection (2002). An Assessment for Renewable Energy Electric Generating Technologies for Florida.

http://www.psc.state.fl.us/industry/electric_gas/Renewable_Energy_Assessment.pdf

Hoff, T.E.; Perez, R.; Braun, G.; Kuhn, M.; Norris, B.; (March 17, 2006) The Value of Distributed Photovoltaics to Austin Energy and the City of Austin. Napa, CA: Clean Power Research LLC, http://www.austinenergy.com/About\%20Us/Newsroom/Reports/PV-ValueReport.pdf (“Austin Energy Report”)

Hoff, T.E. (2002) Final Results Report with a Determination of Stacked Benefits of Both Utility-Owned and Customer-Owned PV Systems. Napa, CA: Clean Power Research, LLC http://www.smud.org/pier/reports/S-034,\%201.3.5.2,\%2012-02,\%20DEL(rev).pdf (“Smud Report")

Hoff, T.E.; Perez, R.; Margolis, R.M. (2005) Maximizing the Value of Customer-Sited PV Systems Using Storage and Controls. Napa, CA: Clean Power Research, LLC http://www.clean-power.com/research/customerPV/OutageProtection_ASES_2005.pdf

Hoff, T.E.; Perez, R.; Margolis, R.M. (November 9, 2004) Increasing the Value of Customer-Owned PV Systems Using Batteries. Napa, CA: Clean Power Research, LLC http://www.clean-power.com/research/customerPV/OutageProtection.pdf

Hoff, T.; Margolis, R. (June 6, 2005). Moving Towards a More Comprehensive Framework to Evaluate Distributed Photovoltaics. Napa, CA: Clean Power Research, LLC and Golden, CO: National Renewable Energy Laboratory http://www.clean-power.com/research/customerPV/EvaluationFramework.pdf

Itron, Inc. (September 14, 2006).CPUC Self-Generation Incentive Program, Preliminary Cost-Effectiveness Evaluation Report.Vancouver, WA

http://www.itron.com/asset.asp?path=assets/itr_001094.pdf

U.S. Department of Energy (no date available) Million Solar Roofs Initiative: Success Stories. Residential Installation, On-Grid PV System, Glenn Dale, MD http://www.nrel.gov/docs/gen/fy98/25718.pdf

Black \& Veatch Corporation (May, 2003). Minnesota Photovoltaic System Case Study: Residential Application. Prepared for Iowa Department of Natural Resources

Navigant Consulting Inc., (February 12, 2006) Distributed Generation and Distribution Planning: An Economic Analysis for the Massachusetts DG Collaborative 
Center for Sustainable Energy at Bronx Community College (January, 2007). New York City's Solar Energy Future Part II: Solar Energy Policies and Barriers in New York City. Prepared for The City University of New York's Million Solar Roofs Initiative. Appendix VI PV Planner Assumptions for all Sectors http://www.bcc.cuny.edu/institutionalDevelopment/cse/Documents/CUNY\%20MSR\%20 -\%20Market\%20for\%20PV\%20in\%20NYC.pdf

New York Energy \$mart. (November, 2004). "Darmstadt Overhead Doors." Fact sheet. http://www.powernaturally.org/About/documents/Darmstadt_SuccessStory.pdf

Perez, R., Letendre, S. (February 2006).Understanding The Benefits of Dispersed GridConnected Photovoltaics: From Avoiding the Next Major Outage to Taming Wholesale Power Markets

http://www.sciencedirect.com

Perez, R.; Hoff, T.; Herig, C.; Shah, J. (May 2003). Maximizing PV Peak Shaving with Solar Load Control: Validation of a Web-Based Economic Evaluation Tool http://www.sciencedirect.com

San Diego Regional Energy Office. (no date available) Del Mar Fairgrounds SelfGen Case Study.

http://www.sdenergy.org/uploads/SelfGen\%20-\%20Case\%20Study\%20-\%20DMFG.pdf

Rabl A.; Spadaro, J.V. (November 2000) Public Health Impact of Air Pollution and Implications for the Energy System http://arjournals.annualreviews.org/doi/pdf/10.1146/annurev.energy.25.1.601

Smellof, E. (January 2005) Quantifying the Benefits of Solar Power for California http://www.votesolar.org/tools_QuantifyingSolar\%27sBenefits.pdf ("The Vote Solar White Paper")

Watts, J.; (Fall 2006) "Solar Power Case Study: An Old Idea With New Economics." Solar Washington Newsletter http://www.solarwashington.org/newsletters/0609/Watts.pdf

Wisconsin Focus On Energy Case Study: Solar Energy in the City (2004). REN-20441104.

http://www.focusonenergy.com/data/common/dmsFiles/W_RS_MKCS_UW\%20Green $\%$ 20 case $\% 20$ study.pdf

Wiser, R.; Mills, A.; Barbose, G.; Golove, W. (July 2007).The Impact of Retail Rate Structures on the Economics of Commercial Photovoltaic Systems in California.LBNL63019, Berkeley, CA: Lawrence Berkeley National Laboratory http://eetd.lbl.gov/ea/ems/reports/63019.pdf 


\section{REPORT DOCUMENTATION PAGE}

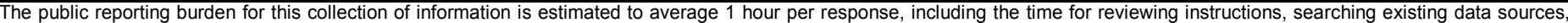

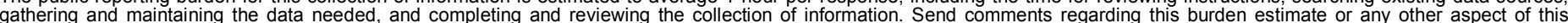

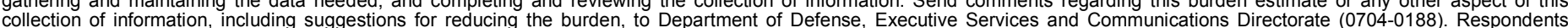

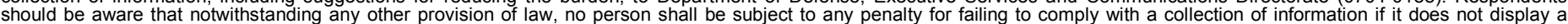

should be aware that notwithstanding

PLEASE DO NOT RETURN YOUR FORM TO THE ABOVE ORGANIZATION.

\begin{tabular}{l|l|l|l} 
1. REPORT DATE $(D D-M M-Y Y Y Y)$ & 2. REPORT TYPE & 3. DATES COVERED (FrOm - TO)
\end{tabular}

February 2008

Subcontract report

4. TITLE AND SUBTITLE

Photovoltaics Value Analysis

5a. CONTRACT NUMBER

DE-AC36-99-G010337

5b. GRANT NUMBER

5c. PROGRAM ELEMENT NUMBER

6. AUTHOR(S)

J.L. Contreras, L. Frantzis, S. Blazewicz, D. Pinault, and H. Sawyer

5d. PROJECT NUMBER

NREL/SR-581-42303

5e. TASK NUMBER

PVB7.6401

5f. WORK UNIT NUMBER
7. PERFORMING ORGANIZATION NAME(S) AND ADDRESS(ES)

Navigant Consulting Inc.

77 South Bedford St.

Burlington, MA 01803

9. SPONSORING/MONITORING AGENCY NAME(S) AND ADDRESS(ES)

National Renewable Energy Laboratory

1617 Cole Blvd.

Golden, CO 80401-3393
8. PERFORMING ORGANIZATION REPORT NUMBER

NREL/SR-581-42303

12. DISTRIBUTION AVAILABILITY STATEMENT

National Technical Information Service

U.S. Department of Commerce

5285 Port Royal Road

Springfield, VA 22161

13. SUPPLEMENTARY NOTES

NREL Technical Monitor: Robert Margolis

14. ABSTRACT (Maximum 200 Words)

The goals of this report are to identify best practices in methodologies for estimating the value of distributed PV technologies, identify gaps in existing knowledge, and outline R\&D opportunities.

\section{SUBJECT TERMS}

photovoltaics; PV; renewable system integration; RSI; value of distributed PV; R\&D opportunities; Navigant Consulting; renewable systems interconnection; National Renewable Energy Laboratory; NREL

\begin{tabular}{|c|c|c|}
\hline \multicolumn{3}{|c|}{ 16. SECURITY CLASSIFICATION OF: } \\
\hline $\begin{array}{l}\text { a. REPORT } \\
\text { Unclassified }\end{array}$ & $\begin{array}{l}\text { b. ABSTRACT } \\
\text { Unclassified }\end{array}$ & $\begin{array}{l}\text { c. THIS PAGE } \\
\text { Unclassified }\end{array}$ \\
\hline
\end{tabular}

\begin{tabular}{l|l} 
17. LIMITATION \\
OF ABSTRACT \\
UL
\end{tabular}

19a. NAME OF RESPONSIBLE PERSON

19b. TELEPHONE NUMBER (Include area code) 